\title{
Breakup volcanism and plate tectonics in the NW Atlantic
}

Article in Tectonophysics · August 2018

DOI: 10.1016/j.tecto.2018.08.002

CITATIONS

9 authors, including:

Mohamed Mansour Abdelmalak

Volcanic Basin Petroleum Research/ CEED, University of Oslo

27 PUBLICATIONS 184 CITATIONS

SEE PROFILE

S. Polteau

Volcanic Basin Petroleum Research

48 PUBLICATIONS 666 CITATIONS

SEE PROFILE
READS

136

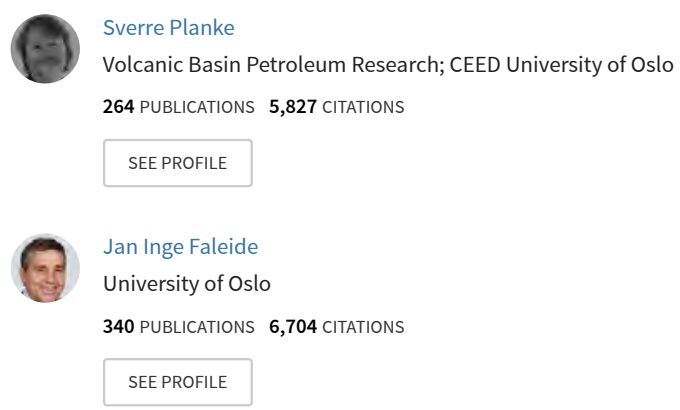

Some of the authors of this publication are also working on these related projects:

Troll Pockmarks View project

PhD project og the development of the Jan Mayen Micro-Continent (JMMC) with its southern continuation into the north-eastern Iceland Plateau, and its implications for possible hydrocarbon systems developments. View project 


\section{Accepted Manuscript}

TEGTONOPHYSICS

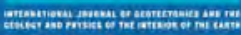

Breakup volcanism and plate tectonics in the NW Atlantic

M.M. Abdelmalak, S. Planke, S. Polteau, E.H. Hartz, J.I. Faleide,

C. Tegner, D.A. Jerram, J.M. Millett, R. Myklebust

PII:

S0040-1951(18)30281-6

DOI:

doi:10.1016/j.tecto.2018.08.002

Reference:

TECTO 127905

To appear in:

Tectonophysics

Received date:

31 July 2017

Revised date:

31 July 2018

Accepted date:

5 August 2018

Please cite this article as: M.M. Abdelmalak, S. Planke, S. Polteau, E.H. Hartz, J.I. Faleide, C. Tegner, D.A. Jerram, J.M. Millett, R. Myklebust, Breakup volcanism and plate tectonics in the NW Atlantic. Tecto (2018), doi:10.1016/j.tecto.2018.08.002

This is a PDF file of an unedited manuscript that has been accepted for publication. As a service to our customers we are providing this early version of the manuscript. The manuscript will undergo copyediting, typesetting, and review of the resulting proof before it is published in its final form. Please note that during the production process errors may be discovered which could affect the content, and all legal disclaimers that apply to the journal pertain. 


\section{Breakup volcanism and plate tectonics in the NW Atlantic}

M.M. Abdelmalak ${ }^{1,2}$ *, S. Planke ${ }^{1,2}$, S. Polteau ${ }^{1}$, E.H. Hartz ${ }^{2,3}$, J.I. Faleide ${ }^{2}$, C. Tegner ${ }^{4}$, D.A. Jerram ${ }^{2,5,6}$, J.M. Millett ${ }^{1,7}$ and R. Myklebust ${ }^{8}$

${ }^{1}$ Volcanic Basin Petroleum Research (VBPR), Oslo Science Park, 0349 Oslo, Norway

${ }^{2}$ Centre for Earth Evolution and Dynamics (CEED), University of Oslo, Norway

${ }^{3}$ Aker BP, Lysaker, Norway

${ }^{4}$ Centre of Earth System Petrology, Department of Geoscience, Aarhus University, Aarhus DK-8000, Denmark

${ }^{5}$ DougalEARTH Ltd., Solihull, UK

${ }^{6}$ Visiting research fellow, Earth, Environmental and Biological Sciences, Queensland University of Technology, Brisbane, Queensland, Australia

${ }^{7}$ Department of Geology and Petroleum Geology, University of Aberdeen, UK

${ }^{8}$ TGS, Lensmannslia 4, 1386 Asker, Norway

*corresponding author: abdelmalak@vbpr.no/m.m.abdelmalak@geo.uio.no / abdelmalak_mansour@yahoo.fr 


\section{Abstract}

Passive margins are the locus of tectonic and magmatic processes leading to the formation of highly variable along-strike and conjugate margins structures. Using extensive new seismic, gravity, and magnetic datasets, complemented by seabed samples and field work, we investigate the tectonomagmatic evolution of the northwest (NW) Atlantic where breakup-related igneous rocks were emplaced during several Paleogene events associated with lithospheric stretching, continental breakup, and the formation of new oceanic basins. Interpretational methods include integrated seismic-gravity-magnetic (SGM) interpretation and seismic volcanostratigraphy. In addition, seabed and field samples were collected and analyzed to constrain the basin stratigraphy, hydrocarbon potential, and the geochronology and geochemistry of the volcanic sequences. Offshore, 2D seismic data reveal several Seaward Dipping Reflector (SDR) wedges and escarpments in the Labrador Sea, Davis Strait, and Baffin Bay. Onshore, eastward prograding foreset-bedded hyaloclastite delta deposits and overlying horizontal lava successions outcrop on Nuussuaq. These hyaloclastites and lava successions are world class analogues to the Lava Delta and Landward Flows volcanic seismic facies units identified offshore. Our mapping results document an aerial extent of the Paleogene breakup-related volcanics of $0.3 \times 10^{6} \mathrm{~km}^{2}$, with an estimated volume of $0.5-0.6 \times 10^{6} \mathrm{~km}^{3}$. Basalt samples recovered by dredging the Upernavik Escarpment have late Paleocene to/early Eocene ages, whereas the sedimentary samples provide an excellent seismic tie with the stratigraphy and the geology in this frontier area. From the integrated SGM interpretation, we identify a rapidly thinning crust and changes in top and intra-basement seismic reflection characteristics in the oceanic domain correlated with transition between different magnetic domains. The mapping results were subsequently integrated in a plate tectonic model. The plate tectonic reconstruction and basalt geochronology suggest that the majority of the volcanism in the NW Atlantic 
occurred between $\sim 62$ and $\sim 58 \mathrm{Ma}$, associated with an increased spreading rate in the Labrador Sea, starting from the onset of the Selandian $(\sim 61.6 \mathrm{Ma})$. A change in the spreading direction during the Eocene ( $\sim 56 \mathrm{Ma})$, synchronously with a shift of volcanic activity from the NW to the NE Atlantic, correspond to a northward drift of Greenland and the initiation of the Eurekan Orogeny. Finally, our interpretations reveal a complex rift configuration along the NW Atlantic conjugate margins both prior to and during breakup.

Keywords: NW Atlantic, Breakup-related magmatism, Seismic volcanostratigraphy, Plate tectonic reconstruction

\section{Introduction}

High quality reflection and refraction seismic surveys reveal different styles of continental margin architecture often referred to as magma-poor or magma-rich margins. Magma-rich, or volcanic passive margins, represent more than $50 \%$ of passive margins worldwide (Coffin and Eldholm, 1994; Eldholm et al., 2000; Skogseid, 2001; Menzies et al., 2002) and are characterized by massive occurrence of mafic extrusive and intrusive rocks (e.g. Eldholm and Grue, 1994; Geoffroy, 2005; Abdelmalak, 2010). In magma-rich margins, magmatic activity is typically expressed within the stretched continental crust by: (1) wedges of seaward-dipping basaltic flows and tuffs extruded at the surface (Hinz, 1981; Planke et al., 2000; Menzies et al., 2002); (2) massive sill/dyke intrusive complexes within the adjacent sedimentary basin (Svensen et al., 2004; Planke et al., 2005) and mafic to ultramafic intrusions within the upper and mid continental crust (Klausen and Larsen, 2002; Geoffroy et al., 2007; Abdelmalak et al., 2015); and (3) deep crustal intrusions at the base of the crust characterized by high $\mathrm{P}$-wave velocites $(\mathrm{Vp}>7.0 \mathrm{~km} / \mathrm{s})$ and interpreted as 
underplated magmatic lower crustal bodies (LCB) (White et al., 1987; Kelemen and Holbrook, 1995; Holbrook et al., 2001) or highly intruded lower crust (White et al., 2008; Abdelmalak et al., 2017a).

Widespread magmatism at volcanic rifted margins is commonly related to (1) mantle-scale thermal anomalies attributed to mantle plumes (White and McKenzie, 1989; Clift and Turner, 1995); (2) small scale convection at the base of the lithosphere (Mutter et al., 1988; King and Anderson, 1995; Simon et al., 2009); (3) heterogeneities in mantle source regions, including composition (e.g. peridotite versus pyroxenite) and volatile contents (e.g. hydrous melting) (Jamtveit et al., 2001; Korenaga, 2004), or (4) thermal anomalies as a result of the lateral rheological variation related to structural inheritance (Schiffer et al., 2017a). In addition, magmatic-related heat flow and lithosphere softening may play a major role in determining the evolution pattern of rifted basins during extension. Therefore, understanding magmatism and extensional processes are fundamental to constrain the formation and evolution of rifted basins into continental passive margins.

The NW Atlantic is an ideal area to evaluate the interplay of tectonomagmatic processes with plate tectonics due to a number of key reasons: (1) a mantle plume may have been involved (e.g., Larsen et al., 2009); (2) both magma-poor and magma-rich segments are present (e.g., Skaarup et al., 2006; Alsulami et al., 2015); (3) a transform margin exists and links two aborted oceanic basins; (4) extension orientations changes as an indication of mantle dynamics during spreading (e.g., Geoffroy et al., 2001; Abdelmalak et al., 2012b; Abdelmalak et al., 2017b), and (5) the asymmetry of the conjugate margin configuration (e.g., Louden and Chian, 1999; Keen et al., 2012). The area therefore, presents an opportunity to study the linkages between these features and plate tectonic models (e.g., Oakey and Chalmers, 2012; Hosseinpour et al., 2013), as well as providing an understanding of the evolution of this margin in the broader context of North Atlantic breakup. 
This contribution presents results from an integrated interpretation using a combined geophysical (seismic, gravity, and magnetic) and seabed sampling data set, along with onshore analogue studies, to better constrain the tectonomagmatic processes and the conjugate margin evolution of the NW Atlantic area. The study utilizes recently acquired geophysical and geological data collected as a part of renewed petroleum exploration activities on the West Greenland shelf and Labrador Sea over the past two decades. Updated maps of breakup-related igneous rocks are presented and used as the basis for interrogating the links between continental breakup and the formation of ocean basins in the NW Atlantic. These new results and compilations are important in terms of understanding the basin structure, plate tectonic development, and igneous processes and deposits.

\section{Geological Setting}

\subsection{Structural and Stratigraphic Frameworks}

\subsubsection{Structural Framework}

The NW Atlantic province consists of the Baffin Bay and Labrador Sea basins separated by the Ungava Fault Zone (UFZ) in the Davis Strait (Fig. 1). Lithospheric stretching between Canada (North American Plate) and West Greenland initiated in Early Cretaceous (Chalmers and Pulvertaft, 2001) ( 140-130 Ma) or Late Jurassic time (Larsen et al., 2009). The E-W Cretaceous continental extension was associated with the formation of a rift system that extended from the southern Labrador Sea to northern Baffin Bay (e.g., Schenk, 2011). The Cretaceous regional extension ended with a rift climax in Late Cretaceous/early Paleocene. Subsequently, regional uplift and erosion in the North Atlantic area has been inferred to be related to the impingement of the proto-Icelandic mantle plume below the Greenland lithosphere at $\sim 65 \mathrm{Ma}$ (Dam et al., 1998a). This uplift was followed by a regional volcanic event during the Paleocene in the NW Atlantic area, leading to 
continental breakup at $\sim \mathrm{C} 27-\mathrm{C} 26(63-61 \mathrm{Ma}$, according to Gradstein et al. 2012 time scale used throughout in this paper) and seafloor spreading in the Labrador Sea and the Baffin Bay. By the earliest Eocene time ( $\sim 56 \mathrm{Ma})$ the breakup started in the NE Atlantic between East Greenland and Europe, while oceanic magnetic anomalies indicate a spreading direction change from EW to NS in the NW Atlantic (Oakey and Chalmers, 2012). After chron C21 ( 48 Ma) seafloor spreading slowed down and stopped in Oligocene time around chron C12-C13 at $33 \mathrm{Ma}$ (Roest and Srivastava, 1989).

\subsubsection{Stratigraphic Framework}

The NW Atlantic Early Cretaceous rifting is documented by clastic sedimentary rock deposition in half-graben and graben basins (the Kitsissut and Appat sequences along the SW Greenland margin and the Bjarni sequences along the SE Canadian side) (Chalmers and Pulvertaft, 2001; Sørensen, 2006; Chalmers, 2012) (Fig. 2). Albian and Aptian units were found offshore and onshore Greenland (e.g., Nøhr-Hansen, 1998; Dam et al., 2000; Gregersen et al., 2013).

In Bylot Island (Fig. 1), middle Albian to possibly Turonian sandstones of the Hassel Formation have been documented (Miall et al., 1980) (Fig. 2). Equivalent Aptian to early Cenomanian deposits of the Quqaluit Formation occur on the southeast coast of Baffin Island (Burden and Langille, 1990) (Fig. 2). Large rift-related grabens that may have acted as intra-continental depocenters for fluvial deltaic sediments are known from the Canadian side of Baffin Bay, including the Eclipse Trough (Miall et al., 1980) and the Lancaster Sound Basin (Harrison et al., 2011). Considering the regional evidence for Lower Cretaceous rift deposits, similar coarse, clastic sediments are most likely present in the conjugate Melville Bay Graben (Fig. 1) and adjacent basins (e.g., Gregersen et al., 2013). 
Upper Cretaceous sequences, developed during the post-rift sag phase, include the Markland Formation on the Canadian margin and the Kangeq sequence on the SW Greenland margin (Sørensen, 2006) where Campanian mudstones were drilled in the Ikermiut-1 and Qulleq-1 wells, and Santonian marine sandstones were identified in the Qulleq-1 well (Christiansen et al., 2001) (Fig. 2). An Upper Cretaceous unconformity separates the deltaic deposits of the upper Albian Atane Formation from the overlying fully marine deposits of the lower Campanian Itilli Formation onshore west Greenland (Dam, 2002; Dam et al., 2009). The widespread extent of Upper Cretaceous marine mudstones above continental and deltaic deposits in Bylot Island (the Kanguk Formation, e.g., McWhae et al., 1980; Miall et al., 1980) and around Baffin Bay suggests that the region was inundated and transgressed during a relative sea-level rise (Gregersen et al., 2013).

Borehole data from west Greenland show that Paleogene lithostratigraphy is dominated by claystones and sandstones of the Ikermiut Formation (Nøhr-Hansen, 2003) (Fig. 2), and marine sands from the Nukik, Hellefisk, and Kangâmiut formations (Rolle, 1985). A widespread hiatus occurs in parts of the west Greenland shelf between late Eocene to mid-Miocene, but sedimentation may have been active elsewhere. From mid-Miocene time, the west Greenland basins subsided until Late Neogene times without further obvious evidence of tectonism (Chalmers and Pulvertaft, 2001; Green et al., 2011). During the Quaternary, thick glacial sediments accumulated in the NW Atlantic with km-thick wedges of Plio-Pleistocene glacial deposits onlapping the region (e.g., Harrison et al., 2011).

\subsection{Nature of Crustal Structure}

The age of the earliest seafloor spreading magnetic anomalies within the Labrador Sea is uncertain due to conflicting interpretations of the nature of the crust within the continent-ocean transition (COT). Roest and Srivastava (1989) interpreted the COT zone as 
oceanic crust containing linear magnetic anomalies C33-C31 ( 80 - 70 Ma) formed during slow seafloor spreading. Other studies have concluded that seafloor spreading started sometime between chron 31 ( 70 Ma) and chron 27 ( 63-62 Ma) (Chian and Louden, 1994; Chian et al., 1995b; Dickie et al., 2011). The COT has also been interpreted as exhumed and serpentinised mantle or high-velocity igneous crust overlain by thin highly fractured and hydrothermally altered oceanic basalts (Chian and Louden, 1994; Lundin and Doré, 2011; Keen et al., 2012). Using reflection seismic profiles, Chalmers (1991); and Chalmers and Pulvertaft (2001) interpreted the magnetic anomalies recorded in the transitional crust as being the result of magmatic intrusion into highly thinned and stretched continental crust. These authors argued that the oldest magnetic anomaly related to seafloor spreading is chron 27, which is considered the oldest undisputed magnetic anomaly in the Labrador Sea.

The nature of the crust within the Davis Strait and the COT northwards into southern Baffin Bay is also debated. Using geophysical data (seismic, gravity, and magnetic) Chalmers and Pulvertaft (2001) described the flank and structural high in Davis Strait as continental, while Srivastava et al. (1982) described the flank as oceanic. Several studies (Funck et al., 2007; 2012; Keen et al., 2012; Suckro et al., 2013) propose that the Ungava Fault Zone in the Davis Strait acted as a leaky transform system where small amounts of oceanic crust may have been produced in the absence of a fully developed oceanic spreading center (Storey et al., 1998; Funck et al., 2007). Funck et al. (2012) interpreted the northward extension of the Ungava Fault Zone as a continuation of the leaky transform fault where remnants of continental crust lay between this zone and the normal oceanic crust of the Baffin Bay (Chalmers and Pulvertaft, 2001; Funck et al., 2012). Alternatively, the northern termination of Ungava Fault Zone is interpreted as Paleocene oceanic crust (Oakey and Chalmers, 2012; Suckro et al., 2012). 
The lack of clear magnetic lineations related to seafloor spreading and sparse coverage of wide-angle seismic measurements lead to a poorly constrained extent of crustal types in the Baffin Bay (Fig. 1). However, modern wide-angle seismic datasets reveal that the southern Baffin Bay is underlain by 6 to $9 \mathrm{~km}$ thick oceanic crust (Funck et al., 2012; Suckro et al., 2012), and the northwestern Baffin Bay is underlain by 3.5 to $6 \mathrm{~km}$ oceanic crust (Altenbernd et al., 2014, 2015). Regional crustal structure derived from 3D gravity inversion modeling shows a good correlation with the seismic reflection data and supports the occurrence of oceanic crust in the center of Baffin Bay (Welford and Dehler, 2016).

\subsection{Magmatism}

Volcanic rocks in the NW Atlantic area range from pre-Cretaceous to EoceneOligocene with a systematic evolution in the composition related to changing stress fields and increasing lithospheric thinning with time (Larsen et al., 2009; 2015). During the period c. 220-150 Ma (Late Triassic to Late Jurassic) stretching started (Larsen et al., 2009). Around $150 \mathrm{Ma}$ (Kimmeridgian), alkaline melts, interpreted to reflect incipient increased extension, formed a $60 \mathrm{~km}$ long dyke swarm exposed onshore SW Greenland (Larsen et al., 2009). In the Late Jurassic/Early Cretaceous, rift-related magmatism is documented on both onshore and offshore conjugate margins of the Labrador Sea (e.g., Peace et al., 2016), as well as in exploration wells e.g. Leif M-48, Roberval K-92, Bjarni H-81, Indian Harbour M52, and Herjolf M-92 wells (Umpleby, 1979, see Figure 4 for well locations). Offshore, on the Canadian side, Late Jurassic/Early Cretaceous magmatism is referred to as the Alexis Formation (the type section is recorded in the Bjarni H-81 well). A more than $400 \mathrm{~km}$-long dyke swarm, indicating rifting, was emplaced in SW Greenland around this time. The alkalibasaltic to enriched tholeiitic compositions indicate larger degrees of melting of 
asthenospheric mantle, likely at shallower depths relative to the previous magmatic events (Larsen et al., 2009)..

Paleogene volcanic rocks occur onshore at Cape Dyer (Fig, 1) (Baffin Island, Canadian margin) and on Disko, Nuussuaq, Ubekendt Ejland, Svartenhuk Halvø and in inland areas further north on the Greenland side (Fig. 3). On central west Greenland, the volcanic stratigraphy established by Hald and Pedersen (1975) was based on observations from the Disko and Nuussuaq region where the picrites of the Vaigat Formation $(\sim 62.5-61$ Ma) are overlain by the depleted basaltic Maligât Formation ( 61-60 Ma) (e.g., Skaarup and Pulvertaft, 2007; Nelson et al., 2015; Pedersen et al., 2017). These two formations present a thickness ranging from 3 to $5 \mathrm{~km}$. Thick picritic lava successions correlated to the Vaigat Formation, make up the entire eastern part of Ubekendt Ejland and continue into the southern and eastern part of Svartenhuk Halvø (Larsen and Pulvertaft, 2000; Pedersen et al., 2017) (Fig. 3). These picritic basalts are overlain by units corresponding to the Svartenhuk Formation on Svartenhuk Halvø, whereas the basalt successions on Ubekendt Ejland are characterized by a greater variety of volcanic rocks (Skaarup and Pulvertaft, 2007; Larsen et al., 2015). The Svartenhuk Formation was assumed to be equivalent to the Maligât Formation (Larsen and Pulvertaft, 2000). A revised volcano-stratigraphic scheme, however, places the less-depleted basalts of the Svartenhuk Formation (58-60 Ma) in the Paleocene above the Maligât Formation (Larsen et al., 2015).

A volcanic quiescent period from 58 to $56 \mathrm{Ma}$ correlates with similar quiescence in East Greenland, and predates the Eocene volcanic event in the NW Atlantic (e.g., Storey et al., 2007; Larsen et al., 2015). An early Eocene age (56-54 Ma) is inferred for the enriched basalts of the Naqerloq Formation defined on Svartenhuk Halvø (Larsen et al., 2015). The west Greenland margin shows clear evidence of (partly eroded) younger lavas and intrusive rocks (Storey et al., 1998), cropping out in Ubekendt Ejland (Nûk takisôq Mb) and in the 
western Nuussuaq area (Kanisut Mb, Fig. 3) with a ${ }^{40} \mathrm{Ar} /{ }^{39} \mathrm{Ar}$ age of 54.1 $\pm 0.29 \mathrm{Ma}$ (Skaarup and Pulvertaft, 2007). Two local successions comprise of $53.5 \mathrm{Ma}$ alkali basalts of Erqua Formation in Ubekendt Ejland and 38.7 Ma transitional basalts of Talerua Member part of Hareøen Formation defined in Hareøen Island (Larsen et al., 2015).

Offshore, seismic reflection data in the northern Labrador Sea, Davis Strait, and Baffin Bay reveal extensive Palaeogene volcanic rocks (Whittaker et al., 1997; Skaarup et al., 2006; Gregersen and Bidstrup, 2008; Gregersen et al., 2013). Williamson et al. (2003) reported ${ }^{40} \mathrm{Ar} /{ }^{39} \mathrm{Ar}$ ages of $62.9 \pm 2.5 \mathrm{Ma}$ and $55.1 \pm 2.3 \mathrm{Ma}$ for dredged basalts off Cape Dyer and in central Davis Strait, respectively (Fig. 1). These ages are within the range obtained from eruptive volcanic rocks in the central west Greenland volcanic province. On the Canadian side, Paleocene basalts were intersected in Hekja-O71 (likely hyaloclastites) and in Gjoa-G37 wells (Fig. 4). Two basalt samples from the Gjoa-G37 well gave ${ }^{40} \mathrm{Ar} /{ }^{39} \mathrm{Ar}$ ages of $59.5 \pm 1.0 \mathrm{Ma}$ and $59.2 \pm 1.8 \mathrm{Ma}$ (Williamson et al., 2001). These ages correlate with the two lower formations in the volcanic succession (Vaigat and Maligât formations) in central west Greenland. Finally, seismic refraction data in the Davis Strait area suggest the presence of kilometers thick magmatic underplating beneath the thinned lithosphere (Funck et al., 2007; Dickie et al., 2011; Keen et al., 2012).

On the SW Greenland side, offshore exploration well Nukik-2 (Fig. 4) encountered $150 \mathrm{~m}$ hyaloclastites and olivine dolerite with low-precision K-Ar ages of $68 \pm 7 \mathrm{Ma}$ and 62 $\pm 6 \mathrm{Ma}$ (Hald and Larsen, 1987). The Hellefisk-1 well (Fig. 4) penetrated $690 \mathrm{~m}$ of volcanic rocks consisting of stacked subaerial lava flows with an average thickness of around $20 \mathrm{~m}$. Williamson et al. (2003) obtained a ${ }^{40} \mathrm{Ar} /{ }^{39} \mathrm{Ar}$ age of $57.7 \pm 1.2 \mathrm{Ma}$ for the lavas from the Hellefisk-1 well, though the position of the samples within the succession was not specified. More recently, the Delta-1 exploration well, offshore central west Greenland, penetrated a 
thick sequence of 65 stacked lava flows (Nelson et al., 2015) with ${ }^{40} \mathrm{Ar} /{ }^{39} \mathrm{Ar}$ ages between 56-51 Ma, similar to the 54.1 Ma Kanisut Member age (Nelson et al., 2015).

\section{Data and Methods}

\subsection{Data}

This contribution is based on the interpretation of a seismic grid of more than 1300 regional industry-standard 2D seismic lines with a total length of more than $220000 \mathrm{~km}$. The data were mainly acquired by TGS and collaborators and processed by TGS. A regular seismic grid is located on the west Greenland shelf and Baffin Bay areas, with several regional profiles extending across the ocean basin to the Canadian margin (Fig. 4). A variable density seismic grid is present in the Davis Strait and Labrador Sea regions. The data is supported by limited publicly available well data (see Figure 4 for well locations), from both offshore and onshore sources (e.g., Rolle, 1985; Balkwill, 1987; Dam et al., 1998b; Chalmers et al., 1999; Christiansen et al., 2001; Sønderholm et al., 2003; Sørensen, 2003; Gregersen and Bidstrup, 2008; Nelson et al., 2015).

Aeromagnetic (c. $240000 \mathrm{~km}$ ) data were acquired by TGS on a regional grid covering most of the west Greenland shelf (Fig. 4). In addition, ship-borne gravity data were acquired along the majority of the seismic profiles shown in Figure 4. The data were processed, gridded, and merged (see Supplementary Material 1 for methodologies)with regional public grids of satellite gravity (Sandwell and Smith, 2009), magnetic compilations (Verhoef et al., 1996), and bathymetry (GEBCO centenary edition). The gravity data are Bouguer corrected using a correction density of $2200 \mathrm{~kg} / \mathrm{m}^{3}$. Both the gravity and magnetic grids are high-pass filtered with cut-off wavelengths of 100, 200 and $400 \mathrm{~km}$, respectively.

Extensive seabed sampling and hydrocarbon seep studies have been completed in the Baffin Bay, Davis Strait, and Labrador Sea areas (Figs. 4 and 5) between 2008 and 2014. 
The seabed sampling also recovered fragments representing subcropping sequences in order to tie seismic data with the stratigraphy and the geology in areas with few or no exploration wells. Onshore-offshore calibration is facilitated by fieldwork undertaken in the onshore Mesozoic-Paleogene basins in the Disko-Nuussuaq area from 2004 to 2011. Seabed sampling is a robust method for identifying and characterizing petroleum systems during the early exploration phases of frontier basins (Polteau et al., 2018). In total, 350 gravity cores, 18 dredges, 79 seawater slick samples, and 18 heat flow stations were collected during these sampling surveys. Conventional organic geochemical analyses were done by Applied Petroleum Technology (APT) and TDI-Brooks. Microseep studies based on the Amplified Geochemical Imaging (AGI) and Microbial Prospecting for Oil and Gas (MPOG) methods were done on 186 and 133 samples, respectively. A variety of onshore analyses, including organic geochemistry (RockEval, gas chromatography), inorganic geochemistry (ICP), petrography, biostratigraphy, and ${ }^{40} \mathrm{Ar} /{ }^{39} \mathrm{Ar}$ dating was done on these samples (see Supplementary Material 1 for methodologies).

Onshore sampling of igneous rocks was done in 2006 in the Disko-Nuussuaq area to characterize the magnetic properties in 25 oriented samples and geochemical compositions in 27 samples (Fig. 3) (see Supplementary Material 2). Samples include 11 lava flows, eight dykes, and four sills. The magnetic analyses (see Supplementary Material 3a) were done at the Norwegian Geological Survey (NGU), whereas the ICP geochemistry was done by Royal Holloway (see Supplementary Material 3b).

\subsection{Methods}

\subsubsection{Seismic Volcanostratigraphy}

The regional seismic interpretation was carried out within the framework of a project covering the entire NW Atlantic using the SMT Kingdom Suite software. In this study, the 
concept of seismic volcanostratigraphy was applied for the interpretation of large volcanic constructions (e.g., Planke et al., 2000; Berndt et al., 2001; Abdelmalak et al., 2016a; Abdelmalak et al., 2016b; Planke et al., 2017). Volcanic successions display a variety of reflection configurations in the subsurface which are indicative of the depositional environment during flood basalt volcanism (e.g. sub-aerial versus sub-aqueous) and the subsequent mass transport of material within the margin (e.g. Planke et al., 2000; Berndt et al., 2001; Wright et al., 2012; Watton et al., 2013; Abdelmalak et al., 2016b; Planke et al., 2017) (Table 1). Several volcanic seismic facies units, typical of volcanic rifted margins, were identified and include: (1) Landward Flows, (2) Lava Delta, (3) Inner Flows, (4) Inner Seaward Dipping Reflectors (Inner SDR), (5) Outer High, and (6) Outer SDR (Planke et al., 2000). In the study area, seismically undifferentiated lava flows were also mapped. Other igneous features like sill intrusion and igneous centres, as well as igneous-related features such as hydrothermal vent complexes, were also mapped, based on the approach in Planke et al. (2015).

\subsubsection{Integrated Seismic, Gravity and Magnetic (SGM) Interpretation}

The different crustal structures were interpreted using integrated seismic-gravitymagnetic (SGM) method. High-pass filtered gravity and magnetic grids were scaled to twoway travel time, converted to pseudo-horizons and loaded into the seismic interpretation project to facilitate the joint interpretation of seismic and potential field data (Abdelmalak et al., 2016b; 2017a) (see Supplementary Material 1 for methodologies) .

Bouguer corrected maps reflect basin and crustal density variations more accurately than free-air high-pass filtered data, and hence are the most useful for geological interpretation (e.g., Berndt, 2002). The Bouguer effect is calculated as if the water layer is replaced by rocks having the same density as nearby sediments at the same depth. On the other hand, 
Bouguer anomaly maps mainly reflect variations in crustal thickness, while high-pass filtered Bouguer anomaly maps allow the removal of regional gravity anomalies caused by density variations in the deep crust and upper mantle. A cut-off wavelength of $100 \mathrm{~km}$ emphasizes density contrasts with a source less than $\sim 10 \mathrm{~km}$, highlighting structural and lithological information of sedimentary basins. On the oceanic crust, the gravity data are used to define fracture zones, transform faults, and extinct and active spreading ridges.

The magnetic anomaly patterns reveal large tectonic trends, depth of magnetic sources in continental crystalline terranes, and patterns of seafloor spreading anomalies. The main magnetic domains as well as the different domain boundaries have been interpreted, in the NW Atlantic. A magnetic domain contains several magnetic anomalies with similar properties in terms of shape, frequency, and amplitude. The crustal structure in the different basin provinces and origin of the regional anomalies were characterized by $2 \mathrm{D}$ potential field modeling using the GMS-SYS and TGS in-house software.

\subsubsection{Plate Tectonic Reconstructions}

Models of tectonic plate motions rely on the integration of multiple geological and geophysical datasets. Magnetic anomalies, which sometime can be correlated to seafloor age, as well as fracture zones and hotspot tracks provide key information to the opening history of ocean basins. However uncertainties related to correlations of magnetic anomalies to seafloor ages are the major limitation for all plate tectonic models. In this contribution, the magnetic and gravimetric crustal domain patterns and their boundaries identified on the conjugate margins have been used as possible isochrons and therefore input for the plate reconstruction model. This approach is supported in the Baffin Bay and in the central parts of the Labrador Sea where the magnetic chrons could not be identified confidently. The 
plate tectonic reconstructions were generated using the GMAP software (Torsvik and Smethurst, 1999).

The motion of a plate is described by an Euler rotation, which is represented by the location of the pole (latitude and longitude) and the rotation angle. Stage poles describe the motion between two time steps, and can be modelled backward in time to generate the finite rotations for all reconstructed stages. Modeled rotations can be used to predict the tectonic regime at a plate boundary, and possible infer its structure or configuration.

\section{Results}

\subsection{Volcanostratigraphy}

\subsubsection{Offshore Volcanics}

Several volcanic seismic facies units typical of a magma-rich margin in the NW Atlantic have been identified. Figure $6 \mathrm{~A}$ shows a lava delta system with well-defined Landward Flows, Lava Delta, and Inner Flows seismic facies units. The Landward Flows are characterized by parallel to subparallel high-amplitude reflections typical of subaerial depositional environments. This unit merges with prograding reflections of the Lava Delta facies unit. The Inner Flows form a sheet-like body of very disrupted or hummocky reflections. A well-defined escarpment marks the transition between the Landward Flows to the Inner Flows.

The well-defined escarpment north of Svartenhuk Halvø in the Upernavik area (Fig. $6 \mathrm{~B})$ is inferred to have formed by erosion or potentially by fault movements. The Upernavik Escarpment was sampled by dredging (Area A2, Fig. 4), and the data revealed a transition between subcropping volcanic rocks and a highly intruded Upernavik Basin. 
In the northern Labrador Sea, flood basalt facies occur in the conjugate margins (Fig. 7). On the Canadian side, oceanward of the Saglek Basin (Fig. 4), a well-defined lava delta system is identified (Fig. 7A). The system shows a small extent and thicknesses of Inner Flows ( 0.2 s), Lava Delta, and Landward Flows seismic facies units. A thick seaward dipping reflector wedge is well-imaged with arcuate and inclined reflections (time thickness between 2 and 4 s). Inclined reflections similar to the ones identified in the Vøring Margin (Abdelmalak et al., 2015) are interpreted as a feeder dyke swarm. The Top basalt reflection has a high impedance contrast and merges with a smooth oceanic top basement reflection (Fig. 7A). The Top basalt is locally irregular, faulted and sometimes shows evidence of pseudo-escarpments.

On the SW Greenland side, a thicker lava delta system $(\sim 1 \mathrm{~s})$ than the one on the Canadian side $(\sim 0.5 \mathrm{~s})$ is observed. The transition between the Landward Flows and the Inner Flows is documented by a well-defined escarpment. A thick SDR seismic facies unit (between 2 and $3 \mathrm{~s}$ ) with a characteristic dyke swarm feeder system is clearly imaged in the seismic data. The SDR terminates near an Outer High where reflections become chaotic and disrupted (Fig. 7B)

A well-defined SDR wedge is also present in the Davis Strait area offshore Cape Dyer. This SDR wedge extends over $80 \mathrm{~km}$ along-strike with thicknesses locally exceeding $3 \mathrm{~s}(\mathrm{c} .6$ to $7 \mathrm{~km}$ ) (Fig. 8A). However, the limited seismic data coverage along the Canadian margin prevented detailed mapping of the SDR wedge. An Outer SDR wedge was also identified on the Greenland side in the SE Baffin Bay within the inferred oceanic crust (Fig. $8 B)$.

Several igneous centers and sill intrusions have, also, been identified. The igneous center shown in Figure 9A has a circular shape with a high-impedance top reflection. The 
presence of escarpments indicates that the volcano edifice rose above the sea surface during the active volcanic period. Sill intrusions are characterized by high amplitude reflections, abrupt termination, common saucer-shaped geometries, and may be associated with hydrothermal vent complexes (Fig. 9B). On seismic reflection data, sill intrusions have different sizes and are identified at different depths.

\subsubsection{Onshore Volcanics}

The central west Greenland documents in outcrop the transition between a sedimentary basin to a volcanic-type passive margin. The different structures such as the border faults along the basement, the Cretaceous-early Paleocene sedimentary strata, and overlapping and sealing of the sedimentary basin by Paleogene volcanism can be observed in an area of about 200 by 300 km (e.g. Larsen et al., 2009; 2015; Abdelmalak, 2010; 2012b)

(Fig. 3). This area represents an excellent analog for the different volcanic facies units identified in seismic reflection data. In Nuussuaq, large continentward wedge-shaped bodies of foreset-bedded hyaloclastite $(\sim 1 \mathrm{~km})$ are overlain by thick and extensive horizontal lava flows $(\sim 1 \mathrm{~km})$ interbedded with thin sedimentary units (Fig. 10A). The eastward prograding foreset-bedded hyaloclastites and the thick horizontal lava piles are analogous to the Lava Delta and the Landward Flows seismic facies unit, respectively. The lava delta developed in a lacustrine environment (Japsen et al., 2005; Dam et al., 2009; Abdelmalak et al., 2012a).

Oceanward the syn-magmatic extension is marked by the formation of thick inclined lava flows. These flows were previously interpreted to represent an Inner SDR wedge in the Svartenhuk Halvø area (Geoffroy et al., 2001; Geoffroy, 2005; Abdelmalak et al., 2007). Different cross-cutting dyke swarm generations with different landward dipping angles are easily identified in the field and are interpreted as the feeders of the SDR (Fig. 10B). Several intra-basalt weathered sedimentary and red soil units are also identified in the field and 
indicate a subaerial environment (Fig. 10C). In addition to the different flood basalt facies, sill intrusions are identified in the sedimentary basin (Fig. 10D). Sometimes, cumulative sill thickness in outcrop exceeds $100 \mathrm{~m}$.

\section{Magnetic properties of onshore samples}

Magnetic analyses were carried out to allow onshore/offshore comparison of magnetic and geological data. Results of rock magnetic properties were used as input parameters for the $2 \mathrm{D}$ potential field modeling. The magnetic susceptibility $\mathrm{K}$ is controlled by the concentration and grain size of ferromagnetic minerals inside a sample. In detail, the average of $\mathrm{K}$ is $8.54 \times 10^{-3} \pm 13.34$ (SI) for dykes, $18.07 \times 10^{-3} \pm 11.90$ (SI) for sills, and $14.08 \times 10^{-3} \pm 5.51(\mathrm{SI})$ for basalt samples. In addition, pyroclastic rocks and felsic intrusions from the Ubekendt Ejland (U2/U3 samples, Fig. 3) have very low K average of $0.54 \times 10^{-3} \pm$ 0.31 (SI). The broad correlation between magnetic susceptibility $\mathrm{K}$ with iron and titanium concentrations suggest that the ferromagnetic minerals in the sill, dyke, and basalt samples were dominated by magnetite and titanomagnetite.

The average natural remnant magnetization for the basalt and dyke samples were 4.2 $\pm 5.4 \mathrm{~A} / \mathrm{m}$ and $2.0 \pm 1.6 \mathrm{~A} / \mathrm{m}$, respectively. Similarly, the Koeningsberger ratio (Q ratio), which measures the ability of a rock to maintain a stable remanence, is $3.8 \pm 8.2$ and $3.7 \pm$ 2.0. Paleomagnetic results indicate a large scatter in both the declination and the inclination, which is only slightly improved after tectonic corrections (see Supplementary Material 3a). Most samples have a reversed magnetization, except three dykes on the Ubekendt Ejland which have a normal magnetization (U1 and U2 in Fig. 3). Typical values of the remnant magnetization are $\pm 70^{\circ}$ and $140^{\circ}$ for the inclination and declination, respectively.

\subsection{Crustal Lineations and Magnetic Domain Boundaries}




\subsubsection{Potential Field Data}

\subsubsection{Gravity Data}

The filtered Bouguer anomaly map for the NW Atlantic is presented in Figure 11. The map reveals a complex pattern with high- and low-amplitude anomalies in the whole area. The 100-km high-pass filtered Bouguer gravity map is very useful for determining the extent of sedimentary basins, locations of structural highs, and the deep crustal structure configuration (Fig. 11). Furthermore a cut-off wavelength of $100 \mathrm{~km}$ emphasizes density contrasts with source depth $<10 \mathrm{~km}$. The extinct spreading ridge is imaged as a NE-trending segment in the central parts of the Labrador Sea and in the Baffin Bay and shows a distinct gravity low with offset indicating the location of fracture zones in some cases (Fig. 11). A high-amplitude gravity anomaly is located along the shelf edge in the entire NW Atlantic, and is interpreted as anomaly YY (about $100 \mathrm{mGal}$ identified on the basis of Bouguer gravity map). Correlated with seismic data, the YY anomaly was interpreted to correspond to a rapid thinning of the crust (Fig. 11). YY is not well defined in the Davis Strait and the northern Baffin Bay due to thick glacial sediments in these areas $(12 \mathrm{~km}$ thick sedimentary wedge in the northern Baffin Bay) (e.g., Harrison et al., 2011). The massive volume of sedimentary cover obscures the gravity data and prevented the detection of the slope topography and leads to increasing uncertainties for determining the basement depth.

In the central part of the Davis Strait, the Ungava Fault Zone (UFZ) connects the two main extinct spreading ridges. This fault zone is imaged as a $>600 \mathrm{~km}$ long NNE-trending zone with positive and negative anomalies. Similarly, a smaller-offset transform boundary is located in the central part of the Baffin Bay (Fig. 11). Finally, the fairly narrow zone between the spreading ridge and the shelf edge anomalies in the Baffin Bay are characterized by a string of broad positive and negative anomalies (Fig. 11). 


\subsubsection{Magnetic Data}

The different magnetic domains and boundaries are identified in the magnetic anomaly map (Fig. 12). In a $\sim 200 \mathrm{~km}$ wide zone surrounding the extinct spreading axis, the Labrador Sea is dominated by broad NW-trending positive magnetic anomalies with poorly defined stripes. This magnetic domain is delimited by the domain boundary X2. Landward of X2 towards Greenland and Canada, a magnetic domain characterized by a series of high frequency and high amplitude anomalies has been identified. This magnetic domain is delimited landward by the domain boundary X1, and forms a continuous 100-150 km wide zone with more linear stripes (Fig. 12). Toward the shelf edge the regional negative magnetic anomaly XX, also identified in the NE Atlantic area, is well defined along the Labrador Sea conjugate margins and Baffin Bay, but is more diffuse in the Davis Strait (Fig. 12). The sediment thickness along the margin is commonly $3-6 \mathrm{~km}(1.5-3 \mathrm{~s})$ as can be seen in the sections given in Figures 13 and 14. This is somewhat increased where thicker glacial sediments are present (e.g. Fig. 11), which can also be seen in the WSW segment of Figure 14A. These variations in sediment thickness have an influence on the resolution and the intensity of the magnetic signal, however their expression can often be traced through from thinner to thicker cover, allowing the anomalies described to be consistently characterized along the margin.

The interpretation of the XX anomaly is difficult as it crosses many geological provinces. Locally the anomaly XX is located along the landward termination of the onshore volcanic complex in the NE and NW Atlantic. However, there is likely to be a correlation between extended crustal and magma emplacement, i.e., magma is dominantly formed and emplaced in regions with extensive lithospheric thinning (e.g., Skogseid et al., 2000). This magnetic anomaly may thus represent both a change in the nature and thickness of magnetic basement 
rocks and magmatic rocks. The magnetic domain X1-XX is characterized by broad NWtrending low-frequency anomalies with poorly defined stripes.

The UFZ is intersected by a NE to NNE curved lineament clearly seen in the magnetic data on both the Canadian and Greenland sides (Fig. 12). On the Greenland side, the lineament, referred to as the "Sisimiut Lineament", intersects the UFZ in an area where the Davis Strait High was segmented and rotated in en-echelon patterns. The trend of the Sisimiut Lineament is parallel to the boundary between the Precambrian terrain boundaries (Early Proterozoic orogeny and Archaean provinces), and therefore possibly represents a very old weakness zone that has been re-activated during the Mesozoic and Cenozoic (e.g., Wilson et al., 2006; Peace et al., 2017b). Finally, a broad NW trending magnetic domain is interpreted in the central part of the Baffin Bay area. This magnetic domain is delineated by the domain boundary $\mathrm{X} 0$.

\subsubsection{Integrated Seismic, Gravity, Magnetic (SGM) Interpretation}

The integrated seismic-gravity-magnetic (SGM) interpretation improves the understanding of both seismic and potential field data, in particular, the nature and extent of sedimentary basins and structural highs. The integrated SGM interpretation shows that many of the detailed observations on the seismic profile have regional significance. Examples of integrated SGM profiles in the Labrador Sea are shown in Figure 13 (BGR11-17, LS Profile1, LS Profile 2). These profiles provide a good seismic tie to the main potential field anomalies and magnetic domains in the Labrador Sea region as they intersect key domain boundaries. Several high- and low-amplitude 100-km Bouguer gravity anomalies are interpreted. A well-defined gravity low in the middle of the transect corresponding to a 40$\mathrm{km}$ wide and $2 \mathrm{~s}(\sim 3 \mathrm{~km})$ deep extinct spreading center imaged on BGR77-17 profile. Gravity highs along the flanks of the valley correspond to an elevated fault-block of 
basement terrain (Fig. 13A). Anomalies $\mathrm{XX}$ and $\mathrm{YY}$ are almost superimposed on the Greenland side, but are well separated on the Canadian side (Fig. 12). However, anomaly YY is difficult to interpret in regions where the crust has been thickened by Paleocene volcanism causing a gradual transition from thick to thin crust (e.g., LS-Profile1 and LSProfile2) and in areas with thick glacial sediments (Fig. 11).

The magnetic domain boundaries correspond to changes in the top- and intrabasement seismic reflection characteristics. In the Labrador Sea, the domain boundary X2 separates a rough block-faulted basement terrain from a terrain with a smoother, subhorizontal top-basement event. The NW termination of domain boundary X1 is located near the landward termination of volcanic complexes on LS-Profile 1 and LS-Profile 2. Prominent high-amplitude reflections are present landward of domain bondary X1 (Fig. 13C). These reflections are interpreted as the top of a volcanic complex even though deeper reflections are commonly present below this surface. These reflections can be interpreted as deeper rift blocks and sedimentary basins beneath the volcanic cover.

In the Davis Strait area, the seismic profile (Fig. 14) crosses the Canadian platform basins (Saglek Basin) in the west before entering the Ungava province to the east. Several hundred kilometers of sinistral transform movement in the Eocene produced large pull-apart basins and transform ridges in the central part of the Ungava province (south Davis Strait High, south Ungava Basin, and Davis Strait Basin) (e.g., Geoffroy et al., 2001).The central UFZ gravity high (named U in Fig. 14A) continues for $>600 \mathrm{~km}$ to the north. Similarly, the deep Ungava Basin is present to the west of the gravity anomaly $U$ for a similar distance. In contrast, the structural highs of Ralegh and Gjoa areas are not associated with pronounced gravity highs (Fig. 14 A). The Davis Strait Basin around Gjoa-G37 well is associated with a negative 100-km Bouguer anomaly, suggesting that the basin structure around the well is an inverted basin. Further east, the profile crosses the southern part of the Lady Franklin Basin 
where several high-amplitude circular gravity and magnetic anomalies are located and are associated with shallowing basement structures (Fig. 14A). This basin was formed during extensive Early Cretaceous rifting, and was later intruded by Paleocene volcanic rocks (e.g., Sørensen, 2006). A prominent structural high is located to the east of the Lady Franklin Basin. Further east the profile crosses the Fylla Structural Complex with major faults and a gentle syncline. The tie with Qulleq-1 well supports the presence of a thick Upper Cretaceous sequence in this area, deposited in an Early Cretaceous basin. However, preCretaceous sedimentary strata are likely found at deeper levels in this basin. Finally, the profile continues up to the southernmost part of the Nukik platform, but the sub-glacial sequence is poorly imaged in this province.

In Baffin Bay, the seismic profile shows a prominent extinct spreading ridge in the central part with a clear and deep V shape (from 6 to $9 \mathrm{~s}$ ) corresponding to a negative gravity anomaly (Fig. 14B). On both sides, landward of the extinct ridge, the top basement is first rough then becomes smoother. Margin segments corresponding to the magnetic domain $\mathrm{XX}-\mathrm{X} 0$ are interpreted as continental blocks and/or exhumed mantle material.

\subsection{Seabed Sampling}

\subsubsection{Sedimentary Rock Samples}

The interpretation of the basin structure and development of the Baffin Bay area offshore W Greenland was based on limited seismic, gravity, and magnetic data, onshore geology of the surrounding regions, and wells drilled $400 \mathrm{~km}$ further south (Whittaker et al., 1997; Gregersen, 2008). In 2008, VBPR/TGS conducted a seabed survey aimed at recovering samples for geology to seismic tie, and for identifying and characterizing possible active petroleum systems in this frontier area (Fig. $15 \mathrm{~A}, \mathrm{~B}$ ). 
In the Baffin Bay, lithified shale fragments (Fig. $15 \mathrm{C}$ ) with abundant organic debris and palynomorphs (Fig. 15 D) were recovered from truncated strata at the seabed in the bit and core catcher at 31 gravity core stations. The biostratigraphic ages of these samples ranged from the Oligocene to Neoproterozoic, with a clustering around the Early Oligocene, the Early Turonian-Late Cenomanian, and the Neoproterozoic. The near in-situ nature of the samples is supported in each individual profile by the narrow stratigraphic interval of samples collected using a gravity corer and a dredge, and the normal younging upward age distribution of gravity core sample.

The numerous samples of the Early Turonian-Late Cenomanian strata from the A2 area (Fig. 4) are typically rich in sapropel, suggesting hydrocarbon source rock potential. Reworked palynological assemblage, identified in these samples, indicate a continentward transgression. The late Cenomanian samples are accumulated in a near-shore environment with a strong influence from land-derived materials. The transition between the Cenomanian and Turonian corresponds to increasing anoxic conditions that are well described elsewhere (Arthur et al., 1987; Schlanger et al., 1987; Klemme and Ulmishek, 1991).

The rest of the stratigraphic samples from areas A3, A4, and A5 (Fig. 4) are Cenozoic in age. In detail, late Paleocene marine shales deposited in an isolated embayment were recovered from Area A3. Oligocene shale fragments were recovered in Area A4, and are dominated by a shallow marine and/or nearshore marine environment with strong influence of land derived palynomorphs. This Oligocene interval also contained very mature late Cenomanian-early Turonian reworked microfossils, thus indicating that uplift and erosion of mature Cretaceous sequences occurred in the Oligocene.

\subsubsection{Volcanic Rock Samples}


Two dredge profiles across the Upernavik Escarpment (dredges 12D and 13D in A5 location, Fig. 4) recovered a large proportion of fresh vesicular basalt (Fig. 15 B, E), indicating that the escarpment is formed by basaltic lava. Four representative samples were analyzed for their composition, and two were selected for ${ }^{40} \mathrm{Ar} /{ }^{39} \mathrm{Ar}$ dating giving plateau ages of $58.3 \pm 1.6 \mathrm{Ma}$ and $53.8 \pm 4.1 \mathrm{Ma}$ supporting a late Paleocene/early Eocene age for the volcanism (see Supplementary Material 4a). The geochemical compositions show that these four basalts are evolved tholeiites (geochemistry details in Supplementary Material 4b). In a TAS diagram $\left(\mathrm{Na}_{2} \mathrm{O}+\mathrm{K}_{2} \mathrm{O}\right.$ vs $\left.\mathrm{SiO}_{2}\right)$ the four samples plot in the sub-alkaline basalt field (Fig. 16A). Trace element compositions display similar trends (e.g. Ce/Y vs $\mathrm{Zr} / \mathrm{Nb}$ in Fig. 16b) to those of the late Paleocene/early Eocene age of Svartenhuk Fm which outcrops onshore. The rare earth elements (REE) show chondrite normalized patterns enriched in the light relative to the heavy elements (Fig. 16c). Similarly, the multi-element patterns show the highest enrichments for the most incompatible elements (e.g., 10-23 times relative to Primitive Mantle values for $\mathrm{Nb}$ ) (Fig. 16d). The concentrations and patterns of the most incompatible trace elements (light REE, high-field strength elements) fall between that of typical ocean island basalt (OIB) and enriched mid-ocean ridge basalt (E-MORB), but are distinctly different from normal, depleted mid-ocean ridge basalt (N-MORB) (Figs. 16c and d). The middle and heavy REE are distinct in the way their concentrations exceed OIB, E-MORB and N-MORB and show a slope of middle to heavy REE (e.g. Dy/Yb normalized to chondrite) that is higher than N-MORB and E-MORB, but lower than OIB. REE element concentrations increase as a function of fractional crystallization in basaltic melts due to their incompatibility with all early crystallizing phases, which, along with the relatively evolved nature of the samples (5-6 wt.\% MgO) compared to typical MORB, explains the relatively elevated absolute values of the REE. The gradient in the heavy REE profiles suggests at least some melting within the garnet stability field of the mantle, in turn 
implying potentially elevated temperatures and at least some melting $>2.7 \mathrm{GPa}$ (Hole and Millett, 2016).

\section{Tectonomagmatic Map}

\subsection{Volcanism in the NW Atlantic Area}

In the NW Atlantic area, the new mapping results show that extrusive volcanism covers an extensive area of $\sim 300000 \mathrm{~km}^{2}$, including well-developed lava delta systems and associated Escarpments, thick SDR wedges and Outer Highs (see Fig. 17 for facies distribution). One lava delta system was also identified to the north of Nukik Platform (NP in Fig. 17). This lava delta cannot be tied confidently to the surrounding regional volcanism due to spare seismic data coverage, and could instead represent a local event. Undifferentiated lava flows occur in the whole area. West of Kivoq Basin (KB in Fig. 17) lava flows are situated at the northernmost extent of one of the N-S fracture zone in the Baffin Bay.

To calculate the extrusive volume in the NW Atlantic area, an average velocity of 4 to $5 \mathrm{~km} / \mathrm{s}$ in the basalt is used (e.g. Planke, 1994; Jerram et al., 2009). Such velocities are within sonic log velocities measured for lava flows in Delta-1 well offshore west Greenland (Nelson et al., 2015). As such, the thickness of volcanic sequences increases from several hundred meters in the Inner Flows to more than $5 \mathrm{~km}$ in the SDR domain. Calculated an average thickness for the different volcanic facies units are: 100 to $400 \mathrm{~m}$ for the Inner Flows, $3 \mathrm{~km}$ for the Inner SDR, and $1 \mathrm{~km}$ for the Outer SDR. The total stratigraphic thickness of the exposed Paleogene extrusive sequence is $\sim 3 \mathrm{~km}$ on Disko and up to $\sim 5 \mathrm{~km}$ on Ubekendt Ejland and Svartenhuk Halvø (e.g., Storey et al., 1998). It is assumed that both the onshore and offshore extrusive sequences in the central west Greenland have an average 
thickness of $3 \mathrm{~km}$. Average thickness ranges between 200 and $400 \mathrm{~m}$ for the undifferentiated lava flows on the Greenland side and an average thickness of $200 \mathrm{~m}$ for the inferred lava flows on the Canadian side, are also considered. An average eroded basalt thickness of $1 \mathrm{~km}$ is estimated onshore Greenland by Japsen et al. (2009). Taking into account the above thicknesses information, a total volume of the extrusive complexes in the NW Atlantic is calculated in the order of $\sim 0.5$ to $0.6 \times 106 \mathrm{~km} 3$.

Sub-volcanic sill intrusions cover an area of $\sim 130000 \mathrm{~km} 2$ where they are mostly mapped in the Saglek Basin, the Lady Franklin Basin, the Sisimiut Basin, the Fylla Structural Complex and the central west Greenland basin (Fig. 17).

The sills and associated vent complexes extent and volume are poorly constrained due to the limited imaging beneath sills/volcanics, and to the difficulty in measuring sill thickness from seismic data (e.g., Angkasa et al., 2017). Sub-sill imaging remains difficult partly due to transmission loss across high-impedance contrast boundaries. In addition, offset-dependent tuning, complex 3D geometries of sills, velocity increases in the metamorphic aureole and structural variations in the overburden commonly increase the difficulty in obtaining good imaging (Planke et al., 2005; 2015). Several levels of sill intrusions can be interpreted, but the continuity of deeper sills is commonly lost when the thickness and/or number of the overlying sills increases. Therefore a large amount of intrusive material could potentially have been missed (Schofield et al., 2017). By considering an average sill thickness of 50-200 m, the total volume for the sill complex in the NW Atlantic area is in the order of 1 to $4 \times 10^{4} \mathrm{~km}^{3}$.

\subsection{Crustal Structure}


The different crustal structures for the NW Atlantic area have been interpreted using the integrated SGM method (Fig. 17). The gravity data defines the location of the extinct spreading ridge and transform faults in the area (Fig. 11). The high-amplitude gravity anomaly $\mathrm{YY}$ is interpreted to correspond to a rapid thinning of the crust. Conjugate anomalies YY indicate asymmetry of the conjugate margins with a narrower crustal thinning zone in the SW Greenland margin and a much broader thinning zone on the Canadian side. Our interpretation is supported by results from seismic data in the Labrador Sea (Chian et al., 1995a; Louden and Chian, 1999; Chalmers and Pulvertaft, 2001; Chalmers, 2012; Keen et al., 2012). On the Baffin Bay, conjugate anomalies YY indicate a much broader thinning zone in the NW Greenland side compared to the narrower crustal thinning zone on the Canadian side. The anomalies YY might be related to the early Cretaceous extension $(\sim 140$ $130 \mathrm{Ma})$ and magmatic event in the area.

Magnetic domains are identified along the oceanic crust in the Labrador Sea and the Baffin Bay areas. Ages of these domain boundaries are tentatively assigned based on available geological and geophysical information in the region (Figs. 11-14). The magnetic domain boundary $\mathrm{X} 3$ is interpreted near the eastward termination of the extinct spreading ridge at $\sim \mathrm{C} 13$ in the NE Atlantic (Fig. 12), thus corresponding to an age of $\sim 33 \mathrm{Ma}$ or slightly older.

In the Labrador Sea, the positive correlation between the magnetic domain boundary X1 and the interpreted $\mathrm{C} 27(\sim 62 \mathrm{Ma})$ and between the magnetic domain boundary $\mathrm{X} 2$ and the interpreted C24 ( 56 Ma) indicate that the magnetic domain X1-X2 was most likely formed during 62-56 Ma period (Fig. 12). The suggested ages for this domain are also based on regional dating of Paleocene volcanic rocks in the NW Atlantic area and correlation into the NE Atlantic, including constraints from scientific boreholes (e.g., Saunders et al., 1997, for ODP legs 152 and 163) (see Figure 12 for the ODP location). 
The magnetic anomalies within domain $\mathrm{XX}-\mathrm{X} 1$ lack the typical bands of alternating normal and reverse polarity indicative of seafloor spreading, so the nature of the crust in this area is most likely of transitional type (Chian and Louden, 1994; Chian et al., 1995a). Refraction data across the conjugate margins of the Labrador Sea indicate that along the magnetic domain $\mathrm{XX}-\mathrm{X} 1$ the crust is approximately $6 \mathrm{~km}$ thick and contain serpentinized mantle peridotite ridges and slivers of highly thinned continental crust (e.g., Chalmers, 2012). The age of the XX anomaly is poorly constrained but is interpreted to be Cretaceous since the domains occur directly north of Cretaceous sea floor spreading between Newfoundland (south of Labrador Sea) and Iberia (Eddy et al., 2017). However, the good correlation between anomalies YY (related to the early Cretaceous extension) and XX can indicate that these two anomalies might be related to the same early Cretaceous extension in the NW Atlantic area. Thus an age of $\sim 140-130$ Ma has been assigned to the XX anomaly. The thin crust in the transition zone in the Labrador Sea passes northwestward into a volcanic margin where seafloor spreading appears to have been sub-aerial during the Paleocene (Chalmers and Laursen, 1995). From the seismic data, the Paleocene oceanic crust is characterized by a smooth basement configuration, whereas the Eocene oceanic crust has a rough character (Fig. 13A).

Although the evolution of Baffin Bay is closely related to the evolution of the Labrador Sea, no clear magnetic spreading anomalies are identified there. Therefore, the nature and evolution of oceanic crust in Baffin Bay remains uncertain (e.g., Suckro et al., 2012). Only one magnetic conjugate domain, bounded by domain boundary $\mathrm{X} 0$, was identified (Fig. 12) which is of unknown age. Oakey and Chalmers (2012) reinterpreted published shipborne magnetic profiles in central Baffin Bay to reveal a Paleocene spreading center and, subsequently defined the limits of both Eocene and Paleocene oceanic crust. However, the magnetic domain between conjugate domain boundaries $\mathrm{X} 0$ is similar to the Eocene 
magnetic domain in the Labrador Sea in terms of shape, frequency and amplitude. Nevertheless, the oceanic basement shows distinct characteristics with a rough shape around the extinct spreading ridge (Fig 14B), similar to the Eocene oceanic basement in the Labrador Sea (Fig. 13A), and a smoother segment of possible Paleocene oceanic or transitional crust (Fig. 14B) similar to the Paleocene smooth oceanic basement in the Labrador Sea. Conjugate magnetic domains XX-X0 are interpreted to be related to the same early Cretaceous rifting episodes identified in the Labrador Sea.

The Labrador Sea and Baffin Bay are connected through the Davis Strait transform area. Our integrated SGM interpretation along the southern Davis Strait profile (Fig. 14A) does not support the presence of oceanic crust on the flanks of the structural high (e.g., Srivastava et al., 1982), but supports continental crust as suggested by Chalmers and Pulvertaft (2001) for approximately the same area.

\section{Plate Tectonic Reconstruction}

Finite and stage rotations were calculated (Supplementary Material 5) by fitting the conjugate gravimetric anomalies and the magnetic domain boundaries described in chapter 5. To evaluate the direction of motion for different time periods in the NW Atlantic small circles are drawn around the stage poles with $5^{\circ}$ spacing. The small circles represent the relative displacement for Greenland moving away from North America. Structures that are perpendicular to the small circles are in extension or compression regime, depending on the tectonic context, whereas structures parallel to the small circles are in strike-slip regime. Structures that are oblique to the small circles are in trantention or transpression. The stage poles from the present study are illustrated in Figures 18 A-D. To illustrate the displacement of Greenland away from North America selected points from the coastline of west Greenland (Fig. 18E) are reconstructed to $170 \mathrm{Ma}$ (in 2 million years intervals). Figure $18 \mathrm{~F}$ 
illustrates a comparison between the location our modelled stage poles and those of Bullard et al. (1965); Torsvik et al. (2008); Oakey and Chalmers (2012). In the NW Atlantic, stretching started during the period c. 220-150 Ma (Late Triassic to Late Jurassic) (Larsen et al., 2009). This stretching event is the consequence of the northward rift system propagation after the breakup of the central Atlantic margins at around 190 Ma (Labails et al., 2010). However the precise age of the starting of extension in the NW Atlantic is not well constrained. Figure 18E illustrates both the direction and the velocity of displacement, from $170 \mathrm{Ma}$ and onwards, which are described in more detail below.

\section{- XX to X1}

In this plate model continental extension is considered to have started at $170 \mathrm{Ma}$. At around 140-130 Ma, the model displays a good fit of anomaly YY (bold red and blue lines in Fig. 18A) in the Labrador Sea and the Baffin Bay. Since XX and YY anomalies are more a less superposed (Fig. 12), it is assumed that they are related to the same rifting event. This stage corresponds to the early Cretaceous rifting episode in the NW Atlantic when rift-related volcanic activity occurs in the Labrador Sea (Fig. 18A). However in the lack of precise dating ages, XX anomaly could represent an interval age instead of a simple isochron. Of course, as the age and complexity of subsequent plate motions increases so will the uncertainties of the reconstructed positions. The small circles in Figure 18A give an indication about the major tectonic features with extension in the Labrador Sea, Baffin Bay, and Lancaster Sound, and oblique extension along the Ungava Fault Zone. A large overlap in the southern UFZ (red and blue bold lines in Fig. 18) suggests major and slow continental extension, marked by the closely spaced grey circles in Figure 18E.

The final closure pole is uncertain since reliable dates are lacking. However, the stage poles presented for continental extension between Greenland and North America in this study sit 
in the vicinity of the poles for the classic Bullard-fit (Bullard et al., 1965) (Fig. 18F). The first computer-aided fits of continental shelfs, established by Bullard et al. (1965), remain remarkably robust, and the key conclusions of the present (and most other) studies of the opening between Greenland and North America, is in many ways encapsulated in the 'Bullard-fit'.

\section{- $\mathrm{X} 1$ to $\mathrm{X} 2$}

The X1 magnetic domain boundary show a good correlation with the interpreted C27 ( 62 Ma) defined by Chalmers and Pulvertaft (2001). This age corresponds to the initiation of volcanism in the North Atlantic Volcanic Province (Storey et al., 2007; Jones et al., 2017). The entire system is under major and rapid extension, slightly increasing towards the south, as marked by small circles defining paths that are close to perpendicular to all major structures. The model displays a fairly good fit of X1 and X0 domain boundaries in the Labrador Sea and in the Baffin Bay, respectively (Fig. 18B). The greater distances between the circle markers of this time interval (Fig. 18E) suggest a higher rate for the separation between Greenland and North America.

The inferred late Paleocene stress field, defined on the basis of the inversion of faultslip data sets and magma driven fractures, indicates that minimum principal stress axis, $\sigma 3$, is oriented NE-SW (Abdelmalak et al., 2012b). This direction shows a perfect match with the plate motion (Fig. 18E) where the modelled marker circles path represents the least horizontal stress axis $\sigma 3$ in this extensional system.

\section{- X2 to X3}

The X2 magnetic domain boundary show a good correlation with the interpreted C24 ( $56 \mathrm{Ma})$ defined by Chalmers and Pulvertaft (2001). The time corresponding to a tight fit 
of X2 domain boundary in the Labrador Sea (Fig. 18C) represents the beginning of a new displacement regime where Greenland travels north relative to North America. During the Eocene, the displacement vectors mark near-orthogonal extension between plates in the Labrador Sea. The kinematic system is characterized by the development of major shearrelated structures along the UFZ, and the Early Cenozoic Eurekan fold and thrust belt of Ellesmere Island and northwest Greenland (Tegner et al., 2011; Piepjohn et al., 2016) (Figs. 18C and E). The modelled marker circles are much closer to each other compared to the X1X2 period (Fig. 18E). This illustrates that spreading between North America and Greenland slows down in the Eocene. This decrease in spreading rate is related to the opening of the NE Atlantic (Gaina et al., 2009, and references therein) so that the displacement between Eurasia and North America that started at $56 \mathrm{Ma}$ was distributed between two spreading centers rather than one. Abdelmalak et al. (2012b) demonstrated that early Eocene stress in central west Greenland displays a $\sigma 3$ parallel to the coastline (north-south in its present position) and parallel to the small circles in Figure 18D. The Eocene stage poles calculated in this study agree fairly well with the one calculated by Oakey and Chalmers (2012) (Fig. $18 \mathrm{~F}$ ), and suggest that the Labrador Sea is in extension whereas the Ungava FZ and Baffin Bay are dominated by shear motion.

The relative plate tectonic motion of the Early Eocene was continued in the late Eocene to Oligocene. During this period, the Labrador Sea is in extension, the Ungava Fault Zone is in left-lateral shear, with evidences of transpression (e.g., Oakey and Chalmers, 2012). Baffin Bay is in shear motion, and the northwestern corner of Greenland is in compression (Fig. 18D). The displacement of Greenland is slowing down (Fig. 18E) and completely stops at >33 Ma (e.g., Roest and Srivastava, 1989), very close to X3 magnetic domain boundary (Figs. 12). The Eocene-Oligocene stage poles sit in the vicinity of the poles of Torsvik et al. (2008) and support a compression the NW of Greenland. 


\section{Discussion}

\subsection{Relations Between Volcanism and Plate Tectonics}

\subsubsection{Age and Distribution of Volcanism}

In the Paleogene, extensive offshore volcanism occurred in the NW Atlantic (Fig. 17) where the main flood basalts were erupted in two phases. The first phase of volcanic activity is constrained by ${ }^{40} \mathrm{Ar} /{ }^{39} \mathrm{Ar}$ ages between $62 \pm 1 \mathrm{Ma}$ to $57.0 \pm 0.6 \mathrm{Ma}$, and associated with an increased spreading rate in the Labrador Sea, starting from the onset of the Selandian $(\sim 61.6$ Ma) (Jones et al., 2017). The second eruptive phase is between $57.3 \pm 1$ Ma to $54.0 \pm 0.3 \mathrm{Ma}$ (Saunders et al., 1997; Storey et al., 1998; Larsen et al., 2015).

In the northern Labrador Sea, volcanic sequences are mapped at the continuation of the Paleocene oceanic crust on both conjugate margins where the top oceanic basement is smooth between X1 and X2. Thick SDR wedges (2 to $4 \mathrm{~km}$ thickness) indicate high magma productivity. To the south of the SDR wedges in the Labrador Sea, a sharp transition from magma-rich to magma-poor margins is present (Fig. 17). Northward to the Davis Strait, magma production decreases and consists mainly of stacked lava flows with an average total thickness ranging between $200 \mathrm{~m}$ and $500 \mathrm{~m}$ and sill intrusions in the surrounding sedimentary basin. The oldest Paleocene volcanic rocks dated from the region are tholeiitic basalts dredged from the Davis Strait High with an ${ }^{40} \mathrm{Ar} /{ }^{39} \mathrm{Ar}$ age of $63.0 \pm 0.7 \mathrm{Ma}$ (Larsen and Dalhoff, 2006). The geochemistry of these basalts indicates formation beneath a thinned continental lithospheric lid (Larsen and Dalhoff, 2006). Radiometric ages from wells in the Davis Strait indicate Paleocene ages for the different basaltic samples (Williamson et al., $2001 ; 2003)$

The most extensive and thickest volcanic pile occurs in the SE Baffin Bay near the northern termination of the Davis Strait. There, most of the volcanism is located on the 
Greenland side. On the Canadian side, offshore Cape Dyer, a $>4 \mathrm{~km}$ thick SDR wedge seems to be the conjugate equivalent to an SDR wedge mapped west of the Disko High (Fig. 17). To the west of Kivok Basin lava flows with an average total thickness of $500 \mathrm{~m}$ are mapped to the northern termination of the most prominent N-S fracture zone in the Baffin Bay. An average basaltic thickness of $3 \mathrm{~km}$ is assumed offshore in central west Greenland. The major part of the voluminous volcanic succession onshore west Greenland from Disko to Svartenhuk Halvø (Vaigat, Maligât and Svartenhuk formations) was generated during the period 62-58 Ma (Larsen et al., 2015).

Compared to the known inland lava formations in west Greenland, the samples from the Upernavik Escarpment are distinctly enriched relative to the Maligât Fm (c. 61-60 Ma), but very similar to the basalts of the Svartenhuk Fm $(\sim 60-58 \mathrm{Ma})$, defined and mapped $\sim 100 \mathrm{~km}$ to the south on Svartenhuk Halvø (Fig. 16) (Larsen et al., 2015). Trace element patterns of the Naqerloq Fm $(\sim 56-54 \mathrm{Ma})$ are similar to Svartenhuk Fm, but are generally more enriched (Fig. 16) (Larsen et al., 2015). Hence, the basalts of the Upernavik Escarpment likely correlate with the Svartenhuk Fm. The radiometric ages from Upernavik Escarpment also support a late Paleocene-early Eocene age.

Evidence for Eocene and younger volcanism is found mainly onshore west Greenland and intersected in one offshore well. Onshore, this consists of the Kanissut Member west of Nussuaq ( 2000 m thickness) (Storey et al., 1998), the Naqerloq Formation in Svartenhuk Halvø (Larsen et al., 2015), the Erqua Formation in Ubekendt Ejland ( 150 m thickness) (Storey et al., 1998; Larsen et al., 2015) and the Hareøen Formation (up to $300 \mathrm{~m}$ thickness) (e.g., Nelson et al., 2015). The only indication for the offshore Eocene volcanism currently documented is found within $500 \mathrm{~m}$ of basalts intersected in the Delta-1 well (Fig. 17) (Nelson et al., 2015). Estimates of the volume of 
Eocene volcanism is around the order of 22500 to $45000 \mathrm{~km}^{3}$ based on an area of 45000 $\mathrm{m}^{2}$ (Fig. 18C) and an average thickness between $500 \mathrm{~m}$ and $1000 \mathrm{~m}$.

These results show that most of the volcanism in the NW Atlantic is of Paleocene age and is mostly coeval with continental breakup in the Labrador Sea during the onset of the magnetic anomaly $\mathrm{C} 27$. The main pulse occurs between $\sim 62$ and $\sim 58 \mathrm{Ma}$ with a calculated average magma production rate of $\sim 1.2$ to $1.5 \mathrm{~km}^{3} /$ year. Volcanism continued into the Eocene, with a lower overall volume and areal extent (e.g. Fig. 18C).

\subsubsection{Mantle Plume and Continental Breakup}

A broad thermal anomaly attributed to the proto-Iceland mantle plume has commonly been proposed as the causal mechanism for continental breakup and excess magmatism between Greenland and Canada (Saunders et al., 1997; Nielsen et al., 2002; Funck et al., 2007; Gerlings et al., 2009). In this scenario the arrival of the mantle plume led to the onset of seafloor spreading in the Labrador Sea and widespread magmatism around the Davis Strait (Storey et al., 1998). As summarized by Peace et al. (2017a), observations in the Labrador Sea-Baffin Bay rift system that have been attributed to the arrival of a mantle plume include: (1) uplift of the onshore sedimentary successions (Dam et al., 1998a); (2) onset of seafloor spreading in the Labrador Sea (Gerlings et al., 2009); (3) coeval volcanism in west Greenland and Baffin Island (Larsen and Pedersen, 2000, 2009) and in the NE Atlantic; (4) eruptions of high ${ }^{3} \mathrm{He} /{ }^{4} \mathrm{He}$ (Graham et al., 1998) and low ${ }^{187} \mathrm{Os} /{ }^{188} \mathrm{Os}$ ratios in picrite lavas of the Vaigat Formation (Schaefer et al., 2000); and (5) underplating of the Davis Strait (Funck et al., 2007; Gerlings et al., 2009).

However, the mantle plume model does not explain all observations in the region. Volcanism driven by a mantle plume should start nearest to the plume head and propagate 
radially away (e.g., Franke, 2013). In this context Baffin Bay is proposed to have been much closer to the plume head than the distant Labrador Sea (Lawver and Müller, 1994; Torsvik et al., 2001), yet seafloor spreading was more extensive in the distant Labrador Sea. Furthermore, the Labrador Sea and Baffin Bay progressively opened from south to north (Oakey and Chalmers, 2012), far from the postulated mantle plume. Similar issues with a simple plume model are evidenced by early volcanism within the Hebrides of Scotland, again far from the proposed plume head at this time (e.g., Hole et al., 2015). Therefore, although these facts do not preclude the presence of a mantle plume in themselves, it seems unlikely that seafloor spreading in the Labrador Sea was caused by a mantle plume, and was instead the response to wider plate tectonic forces associated with the opening of the Atlantic Ocean from the south (e.g., Nielsen et al., 2007; Peace et al., 2017a).

In the Davis Strait, seafloor spreading was never fully initiated, and instead developed a 'leaky transform' system (Funck et al., 2007). However, the focus of magmatism in the NW Atlantic is in the Davis Strait (Fig. 17) where the crust is thicker than elsewhere in the Baffin Bay - Labrador Sea rift system. According to depth models of the lithosphere asthenosphere boundary (LAB) (Lebedev et al., 2017; Schiffer et al., 2017b) the lithosphere in Davis Strait may be c. $150 \mathrm{~km}$ thick, compared to only c. $50 \mathrm{~km}$ thick in the Labrador Sea and Baffin Bay (Peace et al., 2017a). These thickness variations have been proposed to induce lateral thermal gradients leading to the initiation of small scale convection cells and adiabatic melting (e.g., Simon et al., 2009). The thicker, continental type lithosphere in the Davis Strait could also have had an insulating effect, elevating temperature and enhancing melting beneath (Whittington et al., 2009), particularly as continental lithosphere persisted longer than in the Labrador Sea and Baffin Bay (Srivastava and Roest, 1999). Whether lithosphere thickness variations associated with the transform 
system can explain the petrogenesis of all observed volcanism within the Davis Strait area is not currently testable due to a lack of sample coverage offshore.

The crust and lithosphere may have remained thicker in the Davis Strait because of its proximity to the Nagssugtoqidian (Van Gool et al., 2002) and Torngat (Funck and Louden, 1999) orogenic belts, as these terranes lay perpendicular to the rift axis (Wilson et al., 2006) and thus may have resisted lithospheric thinning compared to pre-rift terranes adjacent to the Labrador Sea and Baffin Bay (Peace et al., 2017b). The unfavorable orientation of pre-existing terranes may also have contributed to the failure of complete continental breakup between Greenland and Canada (Chalmers and Pulvertaft, 2001; Wilson et al., 2006; Peace et al., 2017b) and successful opening of the Northeast Atlantic between Greenland and Eurasia, exploiting partly the more favorable Caledonian structures to the east of Greenland (Schiffer et al., 2015; Schiffer et al., 2017a).

Alongside these tectonic controls, there remains clear petrological evidence for excess mantle temperatures within the onshore NW Atlantic sequences (Larsen and Pedersen, 2000, 2009; Hole and Millett, 2016). This, along with the clear association between the volume and distribution of volcanism relative to the Davis Strait transform zone, makes this setting of key importance for understanding links between excess temperature melting and non-uniform rifting during continental rupture. The causes of excess melting in the NW Atlantic therefore appears to be multiple and not yet fully understood. It can be argued that this region therefore forms an important target for future scientific drilling, where the linkages between these processes and their effects on continental break-up can be tested.

\subsection{NW Atlantic Tectonomagmatic Synthesis}


The tectonic evolution of the NW Atlantic area is complex and includes multiple phases of rifting, transpressional, and transtensional movement along regional faults (Roest and Srivastava, 1989; Chalmers and Pulvertaft, 2001; Geoffroy, 2001; Geoffroy et al., 2001; Schenk, 2011; Tegner et al., 2011; Piepjohn et al., 2016) (Fig. 19). The E-W extension between the North American and Eurasian plates began during the latest Triassic to Early Jurassic ( 200-190 Ma) (Doré et al., 1999; Brekke, 2000). In the Early Jurassic at about 200-190 Ma, the Central Atlantic opened in association with the Central Atlantic Magmatic Province (CAMP) (Labails et al., 2010). Further north, the latest Triassic - Early Jurassic extensional system is manifested as rifts and basins in the NE Atlantic (Rockall Trough, Goban Spur, Porcupine Basin, NE Greenland margin, Norwegian Sea, and SW Barents Sea) (e.g., Barnett-Moore et al., 2016). During the Middle to Late Jurassic, Faleide et al. (1993) described a shift in the locus of stretching with a focusing in the NE Atlantic-Arctic system.

In the Arctic, the early to mid-Cretaceous time is characterized by the opening of the Amerasia Basin (Gaina et al., 2014) and the formation of the High Arctic Large Igneous Province (HALIP) (125-120 Ma) (e.g., Tegner et al., 2011; Corfu et al., 2013; Polteau et al., 2016) (Fig. 19). In the NE Atlantic, crustal extension was dominated by large-scale E-W divergent motions (e.g., Doré et al., 1999) forming major Jurassic and Cretaceous basins off central-Norway (Møre and Vøring basins) and Ireland (Rockall Trough and Faroe-Shetland Basin), East Greenland, and the southwest Barents Sea (Faleide et al., 1993; Skogseid et al., 2000; Faleide et al., 2008).

Between Iberia and Newfoundland, this phase of extension resulted in breakup of the continental crust along the southern portions of the margins at around $125 \mathrm{Ma}$ leading to mantle lithosphere exhumation (Tucholke et al., 2007). Tugend et al. (2014) argued that the increase in extensional rates between Iberia and Newfoundland may have led to the opening of the Bay of Biscay. Spreading between Iberia and Newfoundland was connected to a rift 
zone adjacent to the Porcupine and Rockall plateau, and continued northwards between Greenland and Eurasia and to the Labrador Sea (between Greenland and North America). As a result, a continental rift system developed from the southern Labrador Sea to northern Baffin Bay (e.g., Schenk, 2011). The mid-Cretaceous period (Aptian-Albian boundary) has been described as a time with an exceptionally warm climate and greenhouse conditions punctuated by the deposition of globally-distributed anoxic organic-rich sediments from the oceanic anoxic events (OAE1A at 121-122 Ma) (Sabatino et al., 2015; Midtkandal et al., 2016) (Fig. 19).

In the Late Cretaceous, thermal subsidence in the NW Atlantic system led to a sag phase across the conjugate rifted margins. During this period, a second anoxic event (OAE2) is recorded at the Cenomanian-Turonian boundary ( $\sim 93 \mathrm{Ma})$. In the Baffin Bay, the OAE2 is characterized by the deposition of sapropel sedimentary layers forming excellent source rocks (Fig. 19 and see Section 4.3.1. Sedimentary rock samples). In the NE Atlantic, subsidence was important in the Vøring and Møre basins, offshore mid-Norway, leading to the accumulation of up to $8 \mathrm{~km}$ of sediments in local depocentres (Scheck-Wenderoth et al., 2007; Abdelmalak et al., 2017a; Theissen-Krah et al., 2017; Zastrozhnov et al., 2018). This subsidence event was followed by another phase of rifting in the late Cretaceous / early Paleocene recorded in the whole North Atlantic area and ended with regional uplift during the Danian (65-62 Ma; Dam et al., 1998a). The tectonic evolution of the area was influenced by the impingement of the proto-Icelandic thermal anomaly that caused uplift, extension and cratonic movements in the late Cretaceous and Paleogene (Harrison et al., 1999).

During the Paleogene (anomaly C27 at about $\sim 62 \mathrm{Ma}$ ), the first linear magnetic anomaly identified in the Labrador Sea indicates the onset of seafloor spreading (Chalmers and Pulvertaft, 2001) and was coeval with onset of onshore flood basalt volcanism in the 
NW Atlantic. In earliest Eocene time ( $\sim 56 \mathrm{Ma})$, in the Labrador Sea and the Baffin Bay, the spreading direction changed from E-W/ENE-WSW to S-N diachronously, from anomaly C25n (57.7-57.1 Ma) in the south to C24n (54.0-52.6 Ma) to the north (Roest and Srivastava, 1989; Oakey and Chalmers, 2012), and concomitant with the development of the Ungava Fault Zone and the postulated oceanic basin that floors the Baffin Bay. During this time, the main continental breakup started in the NE Atlantic between east Greenland and Europe and was associated with large-scale igneous activity and the formation of conjugate volcanic margins. The early Eocene also marked the opening of the Eurasia Basin in the High Arctic as the North American and Eurasian plates experienced extension to accommodate the opening of the Labrador Sea NE Atlantic (e.g., Gaina et al., 2014).

As Greenland progressively drifted north during the Eocene, compressional structures formed when Greenland collided with northern Canada in what is called the Eurekan Orogeny (Tegner et al., 2011; Piepjohn et al., 2016). The northern part of the NW Atlantic province is characterized by these late compressional structures corresponding to inverted extensional structures formed earlier during rifting (Jackson et al., 1992). Seafloor spreading slowed down at C21 ( $\sim 48 \mathrm{Ma})$ to finally stop in Oligocene time around anomalies C12-C13, 33 Ma (Roest and Srivastava, 1989).

During the Neogene, the west Greenland margin experienced 2-3 km uplift in the Nuussuaq basin (Chalmers, 2000) and the eastern Sisimiut Basin (Dalhoff et al., 2003). In the northwest extremities of Baffin Bay (Fig. 1), channel erosion is probably related to this Neogene uplift in the Jones Sound, southern Nares Strait, and Lancaster Sound (Harrison et al., 2011).

\section{Conclusions}


In this paper the tectonomagmatic evolution of the NW Atlantic has been investigated based on integrated multidisciplinary geophysical datasets (seismic, gravity, and magnetic data) and seabed and onshore sampling. This comprehensive dataset have allowed us to better constraint the crustal structure and tectonic development of the NW Atlantic province. This detailed analysis has resulted in the following conclusions:

1) Well-developed lava delta systems are identified by seismic volcanostratigraphy in the conjugate margins of the northern Labrador Sea. Inner Flows seismic facies units and escarpments are well-imaged in seismic data to the west of the Fylla Structure Complex (on the SW Greenland side), in the Saglek Basin (Canadian side), in the Upernavik Basin to the north of Svartenhuk Halvø peninsula and to the north of the Nukik Platform. Several thick SDR wedges are identified in the northern Labrador Sea and in the Davis Strait area. One Outer SDR is mapped in the Baffin Bay. Seismically undifferentiated lava flows occur in northern Labrador Sea, Davis Strait and Baffin Bay.

2) The Paleogene volcanic succession in the NW Atlantic covers an area of $0.3 \times 10^{6} \mathrm{~km}^{2}$ with an estimated volume of $0.5-0.6 \times 10^{6} \mathrm{~km}^{3}$. Sill intrusions with a thickness ranging between 50 and $200 \mathrm{~m}$ cover an area of $\sim 130000 \mathrm{~km}^{2}$ and have an estimated volume of 1 to $4 \times 10^{4} \mathrm{~km}^{3}$.

3) Gravity and magnetic potential field data are used to identify rapid thinning of the crust and changes in top and intra-basement seismic reflection characteristics. This method comprises a robust way to classify the main geological features in regions lacking welldefined seafloor spreading anomalies, such as the NW Atlantic oceanic basins.

4) Seabed sampling of outcropping sequences in Baffin Bay provide a good tie to the seismic data and identified Cenomanian-Turonian source rocks rich in sapropels deposited in anoxic conditions. 
5) Dredge basalt samples in the Melville Bay area document that the Upernavik Escarpment is volcanic in origin with basalts of late Paleocene /early Eocene ages, and with compositions similar to the Svartenhuk Formation.

6) Most of the volcanism in the NW Atlantic is of Paleocene age and is mostly coeval with an increased spreading rate in the Labrador Sea, starting from the onset of the Selandian ( $\sim 61.6 \mathrm{Ma})$. The main pulse of volcanism occurs between $\sim 62$ and $\sim 58 \mathrm{Ma}$ with a calculated average magma production rate of $\sim 1.2$ to $1.5 \mathrm{~km}^{3} /$ year.

7) A plate tectonic reconstruction model is presented for the NW Atlantic area using the linear gravity and magnetic anomalies and showing the different volcanic events identified in this study. From $\sim 62 \mathrm{Ma}$ to $\sim 56 \mathrm{Ma}$ the area is characterized by a fast seafloor spreading with well-defined magnetic anomalies in the Labrador Sea. As previous studies have shown before, major changes in plate motion from E-W/NE-SW to NNE-SSW/N-S in the Labrador Sea and in the Baffin Bay occur during the Eocene at 56 Ma. Volcanic activity focuses in the NE Atlantic whereas in the NW Atlantic, Eocene volcanism shows lower overall volume and areal extent. Finally, compressional structures developed as Greenland progressively drifted north during the Eocene and collided with northern Canada during the Eurekan Orogeny.

\section{Acknowledgments}

The seismic, magnetic, and gravity data presented in this study were provided by TGS. Seismic interpretation was done using HS Kingdom software. Grid interpolations and map compilations were established using Geosoft Oasis Montaj and ArcGis softwares. We would like thank Craig Magee, Alexander Lewis Peace, the Editor and the Associated Editor for helpful comments and guidance that improved the paper. We acknowledge the support from 
the Research Council of Norway through its Center of Excellence funding scheme, project

\section{2 (CEED).}

\section{References}

Abdelmalak, M.M., 2010. Transition Spatio-temporelle entre rift sédimentaire et marge passive volcanique: l'exemple de la Baie de Baffin, Centre Ouest Groenland, (Spatiotemporal transition between a sedimentary basin to a volcanic passive margin: the Baffin Bay case example, Central West Greenland). Available at Université du Maine (France) onnline: http://cyberdoc.univ-lemans.fr/theses/2010/2010LEMA1030.pdf, Le Mans, p. 266.

Abdelmalak, M.M., Andersen, T.B., Planke, S., Faleide, J.I., Corfu, F., Tegner, C., Shephard, G.E., Zastrozhnov, D., Myklebust, R., 2015. The ocean-continent transition in the midNorwegian margin: Insight from seismic data and an onshore Caledonian field analogue. Geology 43, 1011-1014.

Abdelmalak, M.M., Aubourg, C., Geoffroy, L., Laggoun-Deffarge, F., 2012a. A new oilwindow indicator? The magnetic assemblage of claystones from the Baffin Bay volcanic margin. AAPG Bulletin 96, 205-215.

Abdelmalak, M.M., Faleide, J.I., Planke, S., Gernigon, L., Zastrozhnov, D., Shephard, G.E., Myklebust, R., 2017a. The T-Reflection and the deep crustal structure of the Vøring Margin offshore mid-Norway. Tectonics 36, 2017 TC004617.

Abdelmalak, M.M., Geoffroy, L., Angelier, J., Bonin, B., Callot, J.P., Gélard, J.P., Aubourg, C., 2012b. Stress fields acting during lithosphere breakup above a melting mantle: A case example in West Greenland. Tectonophysics 581, 132-143.

Abdelmalak, M.M., Geoffroy, L., Aubourg, C., Planke, S., 2013. Structural and thermal evolution of the SE Baffin Bay margin: insight from West Greenland area, 3P Arctic, Polar Petroleum Potential Conference and Exhibition, Stavanger, Norway.

Abdelmalak, M.M., Leroy, M., Gélard, J.P., Aite, R., Geoffroy, L., 2007. Full 3D structure, tectonic development and modelling of the Svartenhuk inner-SDR wedge (Greenland): a model to explain syn-magmatic break-up in the NE-Atlantic, European Geoscience Union 2007, p. 2616.

Abdelmalak, M.M., Meyer, R., Planke, S., Faleide, J.I., Gernigon, L., Frieling, J., Sluijs, A., G-J., R., Zastrozhnov, D., Theissen-Krah, S., Said, A., Myklebust, R., 2016a. Pre-breakup magmatism on the Vøring Margin: Insight from new sub-basalt imaging and results from Ocean Drilling Program Hole 642E. Tectonophysics 675, 258-274.

Abdelmalak, M.M., Planke, S., Faleide, J.I., Jerram, D.A., Zastrozhnov, D., Eide, S., Myklebust, R., 2016b. The development of volcanic sequences at rifted margins: new insights from the structure and morphology of the Vøring Escarpment, mid-Norwegian Margin. Journal of Geophysical Research: Solid Earth, 2015JB012788.

Abdelmalak, M.M., Planke, S., Polteau, S., Hatz, E.H., 2017b. Tertiary volcanism in the NW Atlantic area: update on the repartition and age, EGU General Assembly, Vienna, Austria, p. 9380. 
Alsulami, S., Paton, D.A., Cornwell, D.G., 2015. Tectonic variation and structural evolution of the West Greenland continental margin. AAPG Bulletin 99, 1689-1711.

Altenbernd, T., Jokat, W., Heyde, I., Damm, V., 2014. A crustal model for northern Melville Bay, Baffin Bay. Journal of Geophysical Research: Solid Earth 119, 2014JB011559.

Altenbernd, T., Jokat, W., Heyde, I., Damm, V., 2015. Geophysical evidence for the extent of crustal types and the type of margin along a profile in the northeastern Baffin Bay. Journal of Geophysical Research: Solid Earth 120, $2015 J B 012307$.

Angkasa, S.S., Jerram, D.A., Millett, J.M., Svensen, H.H., Planke, S., Taylor, R.A., Schofield, N., Howell, J., 2017. Mafic intrusions, hydrothermal venting, and the basaltsediment transition: Linking onshore and offshore examples from the North Atlantic igneous province. Interpretation 5, SK83-SK101.

Arthur, M.A., Schlanger, S.O., Jenkyns, H.C., 1987. The Cenomanian-Turonian Oceanic Anoxic Event, II. Palaeoceanographic controls on organic-matter production and preservation. Geological Society, London, Special Publications 26, 401-420.

Balkwill, H.R., 1987. Labrador Basin: structure and stratigraphic style. In: Beaumont, C. and Tankard, A.J. (Eds), Sedimentary basin and basin forming mechanism. Canadian Society of Petroleum Geologist Memoirs, 12, 17-43.

Barnett-Moore, N., Müller, D.R., Williams, S., Skogseid, J., Seton, M., 2016. A reconstruction of the North Atlantic since the earliest Jurassic. Basin Research, 1-26.

Berndt, C., 2002. Residual Bouguer satellite gravity anomalies reveal basement grain and structural elements of the Vøring Margin, off Norway. Norwegian Journal of Geology 82, 31-36.

Berndt, C., Planke, S., Alvestad, E., Tsikalas, F., Rasmussen, T., 2001. Seismic volcanostratigraphy of the Norwegian Margin: constraints on tectonomagmatic break-up processes. Journal of the Geological Society 158, 413-426.

Braun, A., Kim, H.R., Csatho, B., von Frese, R.R.B., 2007. Gravity- inferred crustal thickness of Greenland. earth and planetary science letters 262, 138-158.

Brekke, H., 2000. The tectonic evolution of the Norwegian Sea Continental Margin with emphasis on the Vøring and Møre Basins. Geological Society, London, Special Publications $167,327-378$.

Bullard, E., Everett, J.E., Smith, A.G., 1965. The Fit of the Continents around the Atlantic. Philosophical Transactions of the Royal Society of London. Series A, Mathematical and Physical Sciences 258, 41-51.

Burden, E.T., Langille, A.B., 1990. Stratigraphy and sedimentology of Cretaceous and Paleocene strata in half-grabens on the southeast coast of Baffin Island, Northwest Territories. Bulletin of Canadian Petroleum Geology 38, 185-196.

Chalmers, J.A., 1991. New evidence on the structure of the Labrador Sea/Greenland continental margin. journal of Geological Society, London 148, 899-908. 
Chalmers, J.A., 2000. Offshore evidence for Neogene uplift in central West Greenland. Global and Planetary Change 24, 311-318.

Chalmers, J.A., 2012. 11 - Labrador Sea, Davis Strait, and Baffin Bay, in: Roberts, D.G., Bally, A.W. (Eds.), Regional Geology and Tectonics: Phanerozoic Passive Margins, Cratonic Basins and Global Tectonic Maps. Elsevier, Boston, pp. 384-435.

Chalmers, J.A., Laursen, K.H., 1995. Labrador Sea: the extent of continental crust and the timing of the start of seafloor spreading. Marine and Petroleum Geology 12, 311-317.

Chalmers, J.A., Pulvertaft, T.C.R., 2001. Development of the continental margins of the Labrador Sea: a review, in: Wilson, R.C.L., Whitmarsh, R.B., Taylor, B., Froitzheim, N. (Eds.), Non-volcanic Rifting of Continental Margins: a Comparison of Evidences from Land and Sea. Geological Society Special Publication, London, pp. 77-105.

Chalmers, J.A., Pulvertaft, T.C.R., Marcussen, C., Pedersen, A.k., 1999. New insight into the structure of the Nuussuaq Basin, central West Greenland. Marine and Petroleum Geology 16, 197-224.

Chian, D., Keen, C., Reid, I., Louden, K.E., 1995a. Evolution of nonvolcanic margins: New results from the conjugate margins of the Labrador Sea. Geology 23, 589-592.

Chian, D., Louden, K.E., 1994. The continent-ocean crustal transition across the southwest Greenland margin. Journal of Geophysical Research: Solid Earth 99, 9117-9135.

Chian, D., Louden, K.E., Reid, I., 1995b. Crustal structure of the Labrador Sea conjugate margin and implication for the formation of nonvolcanic continental margins. journal of geophysical research 100, 24239-24253.

Christiansen, F.G., Bojesen-Koefoed, J.A., Chalmers, J.A., Dalhoff, F., Mathiesen, A., Sonderholm, M., Dam, G., Gregsen, U., Marcussen, C., Nohr-Hensen, H., Piasecki, S., Preuss, T., Pulvertaft, T.C.R., Rasmussen, J.A., Sheldon, E., 2001. Petroleum geological activites in West Greenland in 2000. geology of greenland survey bulletin 189, 1-10.

Clift, P.D., Turner, J., 1995. Dynamic support by the Icelandic plume and vertical tectonics of the northeast Atlantic continental margins. Journal of Geophysical Research: Solid Earth $100,24473-24486$.

Coffin, M.F., Eldholm, O., 1994. Large igneous provinces: crustal structure, dimensions and external consequence. Reviews of Geophysics 32, 1-36.

Corfu, F., Polteau, S., Planke, S., Faleide, J.I., Svensen, H., Zayoncheck, A., Stolbov, N., 2013. U-Pb geochronology of Cretaceous magmatism on Svalbard and Franz Josef Land, Barents Sea Large Igneous Province. Geological Magazine 150, 1127-1135.

Dalhoff, F., Chalmers, J.A., Nøhr-Hansen, H., Rasmussen, J.A., Sheldon, E., 2003. Mapping and facies analysis of Paleocene- Mid-Eocene seismic sequences, offshore southern West Greenland. Marine and Petroleum Geology 20, 935-986.

Dam, G., 2002. Sedimentology of magmatically and structurally controlled outburst valleys along rifted volcanic margins: exemples from the Nuussuaq Basin, West Greenland.

Sedimentology 49, pp 505-532. 
Dam, G., Larsen, M., Sonderholm, M., 1998a. Sedimentary response to mantle plumes: implication from Palaeocene onshore successions, West and East Greenland. Geology 26, 207-210.

Dam, G., Nohr-Hansen, H., Christiansen, F.G., Bosjesen-Kofoed, J.A., Laier, T., 1998b. The oldest marine Cretaceous sediments in west Greenland (Umiivik-1borehole)- record of the Cenomanian-Turonian Anoxic Event? geology of greenland survey bulletin 180, 128-137.

Dam, G., Nohr-Hansen, H., Pedersen, G.K., Sonderholm, M., 2000. Sedimentary and structural evidence of a new early Campanian rift phase in the Nuussuaq Basin, West Greenland. Cretaceous Research 21, 127-154.

Dam, G., Pedersen, G.K., Sonderholm, M., Midtgaard, H., H.,, Larsen, L.M., Nohr-Hansen, H., Pedersen, A.K., 2009. Lithostratigraphy of the Cretaceous-Pleocene Nuussuaq Group, Nuussuaq Bsin, West Greenland. geological survey of Denmark and gdeenland Bulletin 19, 171.

Dickie, K., Keen, C.E., Williams, G.L., Dehler, S.A., 2011. Tectonostratigraphic evolution of the Labrador margin, Atlantic Canada. Marine and Petroleum Geology 28, 1663-1675.

Doré, A.G., Lundin, E.R., Jensen, L.N., Birklamd, Ø., Eliassen, P.E., Fichler, C., 1999. Principal tectonic events in the evolution of the northwest European Atlantic margin. Geological Society, London, Petroleum Geology Conference series 5, 41-61.

Eddy, M.P., Jagoutz, O., Ibañez-Mejia, M., 2017. Timing of initial seafloor spreading in the Newfoundland-Iberia rift. Geology 45, 527-530.

Eldholm, O., Gladczenko, T.P., Skogseid, J., Planke, S., 2000. Atlantic volcanic margins: a comparative study, in: NOTTVEDT, A.e.a. (Ed.), Dynamics of the Norwegian Margin. Geological Society, London. Spetial Publications, London, pp. 411-428.

Eldholm, O., Grue, K., 1994. North Atlantic volcanic margins: Dimensions and production rates. Journal of Geophysical Research 99, 2955-2968.

Faleide, J.I., Tsikalas, F., Breivik, A.J., Mjelde, R., Ritzmann, O., Engen, Ø., Wilson, J., Eldholm, O., 2008. Structure and evolution of the continental margin off Norway and the Barents Sea. Episodes 31, 82-91.

Faleide, J.I., Vågnes, E., Gudlaugsson, S.T., 1993. Late Mesozoic-Cenozoic evolution of the south-western Barents Sea in a regional rift-shear tectonic setting. Marine and Petroleum Geology 10, 186-214.

Franke, D., 2013. Rifting, lithosphere breakup and volcanism: Comparison of magma-poor and volcanic rifted margins. Marine and Petroleum Geology 43, 63-87.

Funck, T., Gohl, K., Damm, V., Heyde, I., 2012. Tectonic evolution of southern Baffin Bay and Davis Strait: Results from a seismic refraction transect between Canada and Greenland. Journal of Geophysical Research: Solid Earth 117, B04107.

Funck, T., Jackson, H.R., Louden, K.E., Klingelhöfer, F., 2007. Seismic study of the transform-rifted margin in Davis Strait between Baffin (Canada) and Greenland: What happens when a plume meets a transform. Journal of Geophysical Research 112, 1-22. 
Funck, T., Louden, K.E., 1999. Wide-angle seismic transect across the Torngat Orogen, northern Labrador: Evidence for a Proterozoic crustal root. Journal of Geophysical Research: Solid Earth 104, 7463-7480.

Gaina, C., Gernigon, L., Ball, P., 2009. Palaeocene-Recent plate boundaries in NE Atlantic and formation of the Jan Mayen microcontinent. Journal of Geological Society, London 166, 601-616.

Gaina, C., Medvedev, S., Torsvik, T.H., Koulakov, I., Werner, S.C., 2014. 4D Arctic: A Glimpse into the Structure and Evolution of the Arctic in the Light of New Geophysical Maps, Plate Tectonics and Tomographic Models. Surveys in Geophysics 35, 1095-1122.

Geoffroy, L., 2001. The structure of volcanic margins: some problematics from the NorthAtlantic/ Labrador-Baffin System. Marine and Petroleum Geology 18, 463-469.

Geoffroy, L., 2005. Volcanic passive margins. Comptes Rendus Géosciences 337, 13951408 .

Geoffroy, L., Aubourg, C., Callot, J.P., Barrat, J.A., 2007. Mechanisms of crustal growth in large igneous provinces: The north Atlantic province as case study. The Geological Society of America Special Paper 430, 747-774.

Geoffroy, L., Callot, J.P., Scaillet, S., Skuce, A.S., Gélard, J.-P., Ravilly, M., Angelier, J., Bonin, B., Cayet, C., Perrot-Galmiche, K., Lepvrier, C., 2001. Southeast Baffin volcanic margin and the North American-Greenland plate separation. Tectonics 20, 566-584.

Gerlings, J., Funck, T., Jackson, H.R., Louden, K.E., Klingelhöfer, F., 2009. Seismic evidence for plume-derived volcanism during formation of the continental margin in southern Davis Strait and northern Labrador Sea. Geophysical Journal International 176, 980-994.

Gradstein, F.M., Ogg, J.G., Schmitz, M.D., Ogg, G.M., 2012. The Geologic time scale 2012.

Graham, D.W., Larsen, L.M., Hanan, B.B., Storey, M., Pedersen, A.K., Lupton, J.E., 1998. Helium isotope composition of the early Iceland mantle plume inferred from the Tertiary picrites of West Greenland. Earth and Planetary Science Letters 160, 241-255.

Green, P.F., Japsen, P., Chalmers, J.A., Bonow, J.M., 2011. Thermochronology, erosion surfaces and missing section in West Greenland. Journal of the Geological Society 168, 817830.

Gregersen, U., 2008. The north-east Baffin Bay region, offshore Greenland - a new frontier petroleum exploration region. Geological Survey of Denmark and Greenland Bulletin 15, 65-68.

Gregersen, U., Bidstrup, T., 2008. Structure and hydrocarbon prospectivity in northern Davis Strait area, offshore West Greenland. Petroleum Geoscience 14, 151-166.

Gregersen, U., Hopper, J.R., Knutz, P.C., 2013. Basin seismic stratigraphy and aspects of prospectivity in the NE Baffin Bay, Northwest Greenland. Marine and Petroleum Geology $46,1-18$. 
Hald, N., Larsen, J.G., 1987. Early Tertiary, low-potassium tholeiites from exploration wells on the West Greenland shelf. Rapp. Grønl. Geol. Unders. 136, 27.

Hald, N., Pedersen, A.K., 1975. Lithostratigraphy of the Early Tertiary volcanic rocks of central West Greenland. Rapport Grønlands Geologiske Undersøgelse 69, 17-27.

Hamann, N.E., Whittaker, R.C., Stemmmerik, L., 2005. Geological development of the Northeast Greenland Shelf, in: DORE ', A.G.V., B. A. (eds) (Ed.), Petroleum Geology: North-West Europe and Global Perspectives-Proceedings of the 6th Petroleum Geology Conference. Geological Society,, London, pp. 887-902.

Harrison, J.C., Brent, T.A., Oakey, G.N., 2011. Chapter 40 Baffin Fan and its inverted rift system of Arctic eastern Canada: stratigraphy, tectonics and petroleum resource potential. Geological Society, London, Memoirs 35, 595-626.

Harrison, J.C., Mayr, U., McNeil, D.H., Sweet, A.R., Eberle, J.J., McIntyre, D.J., Harington, C.R., Chalmers, J.A., Dam, G., Nohr-Hansen, H., 1999. Correlation of Cenozoic sequences of the Canadian Arctic region and Greenland; implications for the tectonic history of northern North America. Bulletin of Canadian Petroleum Geology 47, 223-254.

Hinz, K., 1981. Hypothesis on terrestrial catastrophes: wedges of very thick oceanward dipping layers beneath passive margins - Their origin and palaeoenvironement significance. Geologische Jahrbuch 22, 345-363.

Holbrook, W.S., Larsen, H.C., Korenaga, J., Dahl-Jensen, T., Reid, I.D., Kelemen, P.B., Hopper, J.R., Kent, G.M., Lizarralde, D., Bernstein, S., Detrick, R.S., 2001. Mantle thermal structure and active upwelling during continental breakup in the North Atlantic. Earth and Planetary Science Letters 190, 251-266.

Hole, M.J., Millett, J.M., Rogers, N.W., Jolley, D.W., 2015. Rifting and mafic magmatism in the Hebridean basins. Journal of the Geological Society 172, 218-236.

Hole, M.J., Millett, M.J., 2016. Controls of Mantle Potential Temperature and Lithospheric Thickness on Magmatism in the North Atlantic Igneous Province. J petrology 57, 417-436.

Hosseinpour, M., Müller, R.D., Williams, S.E., Whittaker, J.M., 2013. Full-fit reconstruction of the Labrador Sea and Baffin Bay. Solid Earth 4, 461-479.

Jackson, H.R., Dickie, K., Marillier, F., 1992. A seismic reflection study of northern Baffin Bay: implication for tectonic evolution. Canadian Journal of Earth Sciences 29, 2353-2369.

Jamtveit, B., Brooker, R., Brooks, K., Larsen, L.M., Pedersen, T., 2001. The water content of olivines from the North Atlantic Volcanic Province. Earth and Planetary Science Letters $186,401-415$.

Japsen, P., Bonow, J.M., Green, P.F., Chalmers, J.A., Lidmar-Bergström, K., 2009. Formation, Uplift and dissection of planation surface at passive continental margins - a new approach. Earth Surface Processes and Landforms 34, 683-699.

Japsen, P., Chalmers, J.A., 2000. Neogene uplift and tectonics around the North Atlantic: overview. Global and Planetary Change 24, 165-173. 
Japsen, P., Green, P.F., Chalmers, J.A., 2005. Separation of Palaeogene and Neogene uplift on Nuussuaq, West Greenland. journal of Geological Society, London 162, 299-314.

Jerram, D.A., Single, R.T., Hobbs, R.W., Nelson, C.E., 2009. Understanding the offshore flood basalt sequence using onshore volcanic facies analogues: an example from the FaroeShetland basin. Geological Magazine 146, 353-367.

Jones, M.T., Augland, L.E., Shephard, G.E., Burgess, S.D., Eliassen, G.T., Jochmann, M.M., Friis, B., Jerram, D.A., Planke, S., Svensen, H.H., 2017. Constraining shifts in North Atlantic plate motions during the Palaeocene by U-Pb dating of Svalbard tephra layers. Scientific Reports 7, 6822.

Keen, C.E., Dickie, K., Dehler, S.A., 2012. The volcanic margins of the northern Labrador Sea: Insights to the rifting process. TECTONICS 31, TC1011.

Kelemen, P.B., Holbrook, W.S., 1995. Origin of thick, high-velocity igneous crust along the U.S. East Coast Margin. Journal of Geophysical Research 100, 10077-10094.

King, S.D., Anderson, D.L., 1995. An alternative mechanism of flood basalt formation. Earth and Planetary Science Letters 136, 269-279.

Klausen, M.B., Larsen, H.C., 2002. East Greenland coast-parallel dike swarm and its role in continental breakup, in: Menzies, M.A., Klemperer, S.L., Ebinger, C.J., and Baker, J., (Ed.), Volcanic Rited Margins: Boulder, Colorado. Geological Society of America Special Paper, pp. 362, p 133-158.

Klemme, H.D., Ulmishek, G.F., 1991. Effective petroleum source rocks of the world: Stratigraphic distribution and controlling depositional factors. AAPG Bulletin (American Association of Petroleum Geologists); (United States), Medium: X; Size: Pages: 1809-1851.

Korenaga, J., 2004. Mantle mixing and continental breakup magmatism. Earth and Planetary Science Letters 218, 463-473.

Labails, C., Olivet, J.-L., Aslanian, D., Roest, W.R., 2010. An alternative early opening scenario for the Central Atlantic Ocean. Earth and Planetary Science Letters 297, 355-368.

Larsen, J.G., Pulvertaft, T.C.R., 2000. The structure of the Cretaceous-Palaeogene sedimentary-volcanic area of Svartenhuk Halvo, central West Greenland. geology of greenland survey bulletin 188, 40 .

Larsen, L.M., Dalhoff, F., 2006. Composition, age, and geological and geotectonic significance of igneous rocks dredged from the northern Labrador Sea and the Davis Strait, Danmarks og Grønlands Geologiske Undersøgelse Rapport, p. 46.

Larsen, L.M., Heaman, L.M., Creaser, R.A., Duncan, R.A., Frei, R., Hutchison, M., 2009. Tectonomagmatic events during stretching and basin formation in the Labrador Sea and the Davis Strait: evidence from age and composition of Mesozoic to Palaeogene dyke swarms in West Greenland. Journal of the Geological Society 166, 999-1012.

Larsen, L.M., Pedersen, A.K., 2000. Processes in High-Mg, High-T Magmas: Evidence from Olivine, Chromite and Glass in Palaeogene Picrites from West Greenland. Journal of Petrology 41, 1071-1098. 
Larsen, L.M., Pedersen, A.K., 2009. Petrology of the Paleocene picrites and flood basalts on Disko and Nuussuaq, West Greenland. Journal of Petrology 50, 1667-1711.

Larsen, L.M., Pedersen, A.K., Tegner, C., Duncan, R.A., Hald, N., Larsen, J.G., 2015. Age of Tertiary volcanic rocks on the West Greenland continental margin: volcanic evolution and event correlation to other parts of the North Atlantic Igneous Province. Geological Magazine 153, 487-511.

Lawver, L.A., Müller, R.D., 1994. Iceland hotspot track. Geology 22, 311-314.

Lebedev, S., Schaeffer, A.J., Fullea, J., Pease, V., 2017. Seismic tomography of the Arctic region: inferences for the thermal structure and evolution of the lithosphere. Geological Society, London, Special Publications 460.

Louden, K.E., Chian, D., 1999. The deep structure of non-volcanic rifted continental margins. Philosophical Transactions of the Royal Society of London 357, 767.

Lundin, E.R., Doré, A.G., 2011. Hyperextension, serpentinization, and weakening: A new paradigm for rifted margin compressional deformation. Geology 39, 347-350.

McDonough, W.F., Sun, S.S., 1995. The composition of the Earth. Chemical Geology 120, 223-253.

McWhae, J.R.H., Elie, R., Laughton, K.C., Gunther, P.R., 1980. Structure and spreading history of the northwestern Atlantic region from the Scotian shelf to Baffin Bay. Canadian Society of Petroleum Geologists 28, 299-332.

Menzies, M.A., Klemperer, S.L., Ebinger, C.J., Baker, J., 2002. Characteristics of volcanic rifted margins. geological society of america, 1-14.

Miall, A., Balkwill, H., Hopkins, W., Jr., 1980. Cretaceous and Tertiary sedimentation of the Eclipse trough, Bylot island area, Arctic Canada, and their regional setting. Geol. Surv. Can. Pap. 79, 20.

Midtkandal, I., Svensen, H.H., Planke, S., Corfu, F., Polteau, S., Torsvik, T.H., Faleide, J.I., Grundvåg, S.-A., Selnes, H., Kürschner, W., Olaussen, S., 2016. The Aptian (Early Cretaceous) oceanic anoxic event (OAEla) in Svalbard, Barents Sea, and the absolute age of the Barremian-Aptian boundary. Palaeogeography, Palaeoclimatology, Palaeoecology 463, 126-135.

Mutter, J.C., Buck, W.R., Zehnder, C.M., 1988. Convective partial melting. 1. A model for the formation of thick basaltic sequences during the initiation of spreading. Journal of Geophysical Research 93, 1031-1048.

Nelson, C.E., Jerram, D.A., Clayburn, J.A.P., Halton, A.M., Roberge, J., 2015. Eocene volcanism in offshore southern Baffin Bay. Marine and Petroleum Geology 67, 678-691.

Nielsen, S.B., Stephenson, R., Thomsen, E., 2007. Dynamics of Mid-Palaeocene North Atlantic rifting linked with European intra-plate deformations. Nature 450, 1071-1074. 
Nielsen, T.K., Larsen, H.C., Hopper, J.R., 2002. Contrasting rifted margin styles south of Greenland: implications for mantle plume dynamics. Earth and Planetary Science Letters 200, 271-286.

Nøhr-Hansen, H., 1998. Dinoflagellate cyst stratigraphy of the upper Cretaceous to Paleogene strata from the Hellefisk-1, Ikermiut-1, Kangâmiut-1 and Nukik-1 wells offshore West Greenland. Danmarks Og Gronlands Geologiske Undersoglese Rapport 1998/54, 58.

Nøhr-Hansen, H., 2003. Dinoflagellate cyst stratigraphy of the Palaeogene strata from the Hellefisk-1, Ikermiut-1, Kangamiut-1, Nukik-1,... Marine and Petroleum Geology 20, 9871016.

Oakey, G.N., Chalmers, J.A., 2012. A new model for the Paleogene motion of Greenland relative to North America: Plate reconstructions of the Davis Strait and Nares Strait Regions between Canada and Greenland. JOURNAL OF GEOPHYSICAL RESEARCH doi:10.1029/2011JB008942

Oakey, G.N., Stephenson, R., 2008. Crustal structure of the Innuitian region of Arctic Canada and Greenland from gravity modelling: implications for the Palaeogene Eurekan orogen. Geophysical Journal International 173, 1039-1063.

Peace, A., Foulger, G.R., Schiffer, C., McCaffrey, K.J.W., 2017a. Evolution of Labrador Sea-Baffin Bay: Plate or Plume Processes? Geoscience Canada 44, 91-102.

Peace, A., McCaffrey, K., Imber, J., Phethean, J., Nowell, G., Gerdes, K., Dempsey, E., 2016. An evaluation of Mesozoic rift-related magmatism on the margins of the Labrador Sea: Implications for rifting and passive margin asymmetry. Geosphere.

Peace, A., McCaffrey, K., Imber, J., van Hunen, J., Hobbs, R., Wilson, R., 2017b. The role of pre-existing structures during rifting, continental breakup and transform system development, offshore West Greenland. Basin Research.

Pedersen, A.K., Larsen, L.M., Pedersen, A.K., 2017. Lithostratigraphy, geology and geochemistry of the volcanic rocks of the Vaigat Formation on Disko and Nuussuaq, Paleocene of West Greenland. Geological Survey of Denmark and Greenland Bulletin, 250.

Piepjohn, K., von Gosen, W., Tessensohn, F., 2016. The Eurekan deformation in the Arctic: an outline. Journal of the Geological Society.

Planke, S., 1994. Geophysical response of flood basalts from analysis of wire line logs: Ocean Drilling Program Site 642, Vøring volcanic margin. Journal of Geophysical Research 99, 9279-9296.

Planke, S., Millett, J.M., Maharjan, D., Jerram, D.A., Abdelmalak, M.M., Groth, A., Hoffmann, J., Berdnt, C., Myklebust, R., 2017. Igneous seismic geomorphology of buried lava fields and coastal escarpments on the vøring volcanic rifted margin. Interpretation 5, SK161-SK177.

Planke, S., Rasmussen, T., Rey, T., Myklebust, R., 2005. Seismic characteristics and distribution of volcanic intrusions and hydrothermal vent complexes in the Vøring and Møre 
basins, in: Doré, A.G., and Vining, B. A., (Ed.), Petroleum Geology: North-West Europe and Global Perspectives-Proceedings of the 6th Petroleum Geology Conference. Geological Society, London, pp. 833-844.

Planke, S., Svensen, H., Myklebust, R., Bannister, S., Manton, B., Lorenz, L., 2015. Geophysics and Remote Sensing. Springer Berlin Heidelberg, pp. 1-16.

Planke, S., Symonds, P.A., Avelstad, E., Skogseid, J., 2000. Seismic volcanostratigraphy of large-volume basaltic extrusive complexes on rifted margins. Journal of Geophysical Research 105, 19333-19351.

Polteau, S., Hendriks, B.W.H., Planke, S., Ganerød, M., Corfu, F., Faleide, J.I., Midtkandal, I., Svensen, H.S., Myklebust, R., 2016. The Early Cretaceous Barents Sea Sill Complex: Distribution, 40Ar/39Ar geochronology, and implications for carbon gas formation. Palaeogeography, Palaeoclimatology, Palaeoecology 441, 83-95.

Polteau, S., Mazzini, A., Hansen, G., Planke, S., jerram, D.A., Millett, J.M., Abdelmalak, M.M., Blischke, A., Myklebust, R., 2018. The pre-breakup stratigraphy and petroleum system of the Southern Jan Mayen Ridge revealed by seafloor sampling. Tectonophysics.

Rasmussen, T.A., 2002. Aeromagnetic survey in central West Grennland: project Aeromag 2001. geology of greenland survey bulletin 191, 67-72.

Roest, W.R., Srivastava, S.P., 1989. Sea-floor spreading in the Labrador Sea: a new reconstruction. Geology 17, 1000-1003.

Rolle, F., 1985. Late Cretaceous Tertiary sediments offshore Central West Greenland: lithostratigraphy, sedimentary evolution, and petroleum potential. Canadian Journal of Earth Sciences 22, 1001-1019.

Sabatino, N., Coccioni, R., Salvagio Manta, D., Baudin, F., Vallefuoco, M., Traina, A., Sprovieri, M., 2015. High-resolution chemostratigraphy of the late Aptian-early Albian oceanic anoxic event (OAE 1b) from the Poggio le Guaine section (Umbria-Marche Basin, central Italy). Palaeogeography, Palaeoclimatology, Palaeoecology 426, 319-333.

Sandwell, D.T., Smith, W.H.F., 2009. Global marine gravity from retracked Geosat and ERS-1 altimetry: Ridge segmentation versus spreading rate. Journal of Geophysical Research: Solid Earth 114, B01411.

Saunders, A.D., Fitton, J.G., Kerr, A.C., Norry, M.J., Kent, R.W., 1997. The North Atlantic igneous province, in: Mahoney, J.J., Coffin, M.F. (Eds.), Large Igneous Provinces: Continental, Oceanic, and Planetary Flood Volcanism. AGU Geophysical Monograph, Washington, pp. 45-93.

Schaefer, B.F., Parkinson, I.J., Hawkesworth, C.J., 2000. Deep mantle plume osmium isotope signature from West Greenland Tertiary picrites. Earth and Planetary Science Letters $175,105-118$.

Scheck-Wenderoth, M., Raum, T., Faleide, J.I., Mjelde, R., Horsfield, B., 2007. The transition from the continent to the ocean: a deeper view on the Norwegian margin. Journal of the Geological Society 164, 855-868. 
Schenk, C.J., 2011. Chapter 41 Geology and petroleum potential of the West GreenlandEast Canada Province. Geological Society, London, Memoirs 35, 627-645.

Schiffer, C., Jacobsen, B.H., Balling, N., Ebbing, J., Nielsen, S.B., 2015. The East Greenland Caledonides - teleseismic signature, gravity and isostasy Geophys J Int 203, $1400-1418$.

Schiffer, C., Peace, A., Phethean, J., Gernigon, L., McCaffrey, K., Petersen, K.D., Foulger, G.R., 2017a. The Jan Mayen Microplate Complex and the Wilson Cycle. Geological Society London Special Publications.

Schiffer, C., Tegner, C., Schaeffer, A.J., Pease, V., Nielsen, S.B., 2017b. High Arctic geopotential stress field and implications for geodynamic evolution. Geological Society, London, Special Publications 460.

Schlanger, S.O., Arthur, M.A., Jenkyns, H.C., Scholle, P.A., 1987. The CenomanianTuronian Oceanic Anoxic Event, I. Stratigraphy and distribution of organic carbon-rich beds and the marine $813 \mathrm{C}$ excursion. Geological Society, London, Special Publications 26, 371 399.

Schofield, N., Holford, S., Millett, J., Brown, D., Jolley, D., Passey, S.R., Muirhead, D., Grove, C., Magee, C., Murray, J., Hole, M., Jackson, C.A.L., Stevenson, C., 2017. Regional magma plumbing and emplacement mechanisms of the Faroe-Shetland Sill Complex: implications for magma transport and petroleum systems within sedimentary basins. Basin Research 29, 41-63.

Simon, K., Huismans, R.S., Beaumont, C., 2009. Dynamical modelling of lithospheric extension and small-scale convection: Implications for magmatism during the formation of volcanic rifted margins. Geophysical Journal International 176, 327-350.

Skaarup, N., Jackson, H.R., Oakey, G., 2006. Margin segmentation of Baffin Bay/Davis Strait, eastern Canada based on seismic reflection and potential field data. Marine and Petroleum Geology 23, 127-144.

Skaarup, N., Pulvertaft, T.C.R., 2007. Aspect of the structure on the coast of the West Greenland volcanic province reveled in seismic data. Bulletin of the Geological Society of Danmark 55, 65-80.

Skogseid, J., 2001. Volcanic margins: geodynamic and exploration aspects. Marine and Petroleum Geology 18, 457-461.

Skogseid, J., Planke, S., Faleide, J.I., Pedersen, T., Eldholm, O., Neverdal, F., 2000. NE Atlantic continental rifting and volcanic margin formation, in: NOTTVEDT, A.e.a. (Ed.), Dynamics of the Norwegian Margin. Geological Society, London, Special Publications, London, pp. 295-326.

Srivastava, S.P., MacLean, B., Macnab, R.F., Jackson, H.R., 1982. Davis strait: structure and evolution as obtained from a systematic geophysical survey. In Arctic geology and geophysics. Int. Symposium on Arctic Geology, Canadian Soc. of Petrol. Geologists Memoire 8, 267-278. 
Srivastava, S.P., Roest, W.R., 1999. Extent of oceanic crust in the Labrador Sea. Marine and Petroleum Geology 16, 65-84.

Storey, M., Ducan, R.A., Pedersen, A.K., Larsen, L.M., Larsen, H.C., 1998. ${ }^{40} \mathrm{Ar} /{ }^{39} \mathrm{Ar}$ geochronology of the West Greenland Tertiary volcanic province. Earth and Planetary Science Letters 160, 569-586.

Storey, M., Duncan, A.R., Tegner, C., 2007. Timing and duration of volcanism in the North Atlantic Igneous Province: Implication for geodynamics and links to the Iceland hotspot. Chemical Geology 241, 264-281.

Suckro, S.K., Gohl, K., Funck, T., Heyde, I., Ehrhardt, A., Schreckenberger, B., Gerlings, J., Damm, V., Jokat, W., 2012. The crustal structure of southern Baffin Bay: implications from a seismic refraction experiment. Geophysical Journal International 190, 37-58.

Suckro, S.K., Gohl, K., Funck, T., Heyde, I., Schreckenberger, B., Gerlings, J., Damm, V., 2013. The Davis Strait crust - a transform margin between two oceanic basins. Geophysical Journal International.

Svensen, H., Planke, S., Malthe-Sorenssen, A., Jamtveit, B., Myklebust, R., Rasmussen Eidem, T., Rey, S.S., 2004. Release of methane from a volcanic basin as a mechanism for initial Eocene global warming. Nature 429, 542-545.

Sønderholm, M., Henrik, N.-H., Jorgen, B.-K., Finn, D., Jan Audun, R., 2003. Regional correlation of Mesozoic-Paleogene sequences across the Greenland-Canada bundary. geological survey of Denmark and greenland, 1-54.

Sørensen, A.B., 2003. Cenozoic basin development and stratigraphy of the Faroes area. Petroleum Geoscience 9, 189-207.

Sørensen, A.B., 2006. Stratigraphy, structure and petroleum potential of the Lady Franklin and Maniitsoq Basins, offshore southern West Greenland. Petroleum Geoscience 12, 221234.

Tegner, C., Storey, M., Holm, P.M., Thorarinsson, S.B., Zhao, X., Lo, C.H., Knudsen, M.F., 2011. Magmatism and Eurekan deformation in the High Arctic Large Igneous Province: ${ }^{40} \mathrm{Ar}-{ }^{39} \mathrm{Ar}$ age of Kap Washington Group volcanics, North Greenland. Earth and Planetary Science Letters 303, 203-214.

Theissen-Krah, S., Zastrozhnov, D., Abdelmalak, M.M., Schmid, D.W., Faleide, J.I., Gernigon, L., 2017. Tectonic evolution and extension at the Møre Margin - offshore midNorway. Tectonophysics.

Torsvik, T.H., Mosar, J., Eide, E.A., 2001. Creataceous-Tertiary geodynamics: A North Atlantic exercise. Geophysical Journal International 146, 850-866.

Torsvik, T.H., Müller, R.D., Van der Voo, R., Steinberger, B., Gaina, C., 2008. Global plate motion frames: Toward a unified model. Reviews of Geophysics 46, RG3004.

Torsvik, T.H., Smethurst, M.A., 1999. Plate tectonic modelling: virtual reality with GMAP1GMAP Standard is available as a freeware on http://www.ngu.no/geophysics1. Computers and Geosciences 25, 395-402. 
Tucholke, B.E., Sawyer, D.S., Sibuet, J.-C., 2007. Breakup of the Newfoundland-Iberia rift. Geological Society, London, Special Publications 282, 9-46.

Tugend, J., Manatschal, G., Kusznir, N.J., Masini, E., Mohn, G., Thinon, I., 2014. Formation and deformation of hyperextended rift systems: Insights from rift domain mapping in the Bay of Biscay-Pyrenees. Tectonics 33, 2014 TC003529.

Umpleby, D.C., 1979. Geology of the Labrador Shelf. Geological Survey of Canada Paper, 79-13.

Van Gool, J.A.M., Connelly, J.N., Marker, M., Mengel, F.C., 2002. The Nagssugtiqidian Orogen of West Greenland: tectonic evolution and evolution and regional correlation from a West Grennland perspective. Canadian Journal of Earth Science 63, 665-686.

Verhoef, J., MacNab, R., Roest, W., Arkani-Hamed, J., al., e., 1996. Magnetic anomalies of the Arctic and North Atlantic Oceans and adjacent land areas (GAMM-AA5: Gridded Aeromagnetic and Marine Magnetics of the north Atlantic and Arctic, 5km). Geological Survey of Canada, Open File Report 3125a.

Watton, T.J., Jerram, D.A., Thordarson, T., Davies, R.J., 2013. Three-dimensional lithofacies variations in hyaloclastite deposits. Journal of Volcanology and Geothermal Research 250, 19-33.

Welford, J.K., Dehler, S.A., 2016. Regional Crustal Structure Across Baffin Bay, Northern Canada, From Constrained 3-D Gravity Inversion. Offshore Technology Conference.

White, R.S., McKenzie, D.P., 1989. Magmatism at rift zones: The generation of volcanic continental margins and flood basalts. Journal of Geophysical Research 94, 7685-7729.

White, R.S., Smith, L.K., Roberts, A.W., Christie, P.A.F., Kusznir, N.J., and the rest of the iSIMM Team, 2008. Lower-crustal intrusion on the North Atlantic continental margin. Nature 452, 460-465.

White, R.S., Spence, G.D., Fowler, S.R., McKenzie, D.P., Westbrook, G.K., Bowen, A.N., 1987. Magmatism at rifted continental margins. Nature 330, 439-444.

Whittaker, R.C., Hamann, N.E., Pulvertaft, T.C.R., 1997. A new frontier province offshore northwest Greenland: structure, basin development, and petroleum potential of the Melville Bay Area. AAPG Bulletin 81, 978-998.

Whittington, A.G., Hofmeister, A.M., Nabelek, P.I., 2009. Temperature-dependent thermal diffusivity of the Earth/'s crust and implications for magmatism. Nature 458, 319-321.

Wilkinson, C.M., Ganerød, M., Hendriks, B.W.H., Eide, E.A., 2016. Compilation and appraisal of geochronological data from the North Atlantic Igneous Province (NAIP). Geological Society, London, Special Publications 447.

Williamson, M.-C., Larsen, L.M., Jackson, H.R., Oakey, G.N., 2003. Evolution of the Baffin Island-West Greenland Tertiary Volcanic Province: Evidence from basaltic rocks on the conjugate margins, EGS-AGU-EUG Joint Assembly. Geophysical Research Abstracts, Nice, France. 
Williamson, M.-C., Villeneuve, M.E., Larsen, L.M., Jackson, H.R., Oakey, G.N., MacLean, B., 2001. Age and petrology of offshore basalts from the Southeast Baffin Island Shelf, Davis Strait, and the western Greenland continental margin, Geological Association of Canada / Mineralogical Association of Canada Joint Annual Meeting, St. John's, Newfoundland, Canada, p. 162.

Wilson, R.W., Klint, K.E.S., Van Gool, J.A.M., McCaffrey, K.J.W., Holdsworth, R.E., Chalmers, J.A., 2006. Faults and fractures in central West Greenland: onshore expression of continental break-up and sea-froor spreading in the Labrador - Baffin Bay Sea. geological survey of Denmark and gdeenland 11, 185-204.

Wright, K.A., Davies, R.J., Jerram, D.A., Morris, J., Fletcher, R., 2012. Application of seismic and sequence stratigraphic concepts to a lava-fed delta system in the Faroe-Shetland Basin, UK and Faroes. Basin Research 24, 91-106.

Zastrozhnov, D., Gernigon, L., Gogin, I., Abdelmalak, M.M., Faleide, J.I., Planke, S., Eide, S., Myklebust, R., 2018. Cretaceous-Paleocene evolution and crustal structure of the Northern Vøring Margin (offshore Mid-Norway): results from integrated geological and geophysical study. TECTONICS, 2017 TC004655. 


\section{Figures captions}

Fig. 1. Structural map of the NW Atlantic showing the Cretaceous basins and the extent of Paleogene volcanics. The different proposed continent-ocean boundaries (COBs) are shown. The magnetic lineations and fracture zones are from Chalmers (2012). Radiometric ages for volcanic samples are from Larsen et al. (2009); Abdelmalak et al. (2012b); Larsen et al. (2015); Nelson et al. (2015); and Wilkinson et al. (2016). CGFZ: Chalie-Gibbs Fracture Zone; CFZ: Cartwright Fracture Zone; ER: Eirik Ridge; FSC: Fylla Structure Complex; HB: Hopedale Basin; KB: Kivoq Basin; LFP: Lady Franklin Basin; LFZ: Leif Fracture Zone; NB: Nuuk Basin; NP: Nukik Platform; NuB: Nuussuaq Basin; MB: Melville Basin; OB: Orphan Basin; SaB: Saglek Basin; SB: Sisimiut Basin; UFZ: Ungava Fault Zone.

Fig. 2. Summary table of the stratigraphy of the NW Atlantic modified from Sørensen (2006); and Gregersen et al. (2013). Stratigraphy for SW Greenland shelf: I Fm: Ikermiut Fm; K Fm: Kangâmiut Formation; N Fm: Nukik Fm; M Fm: Manîtsoq Fm. Stratigraphy for Nuussuaq Basin: Kan Fm: Kangilia Fm; S Fm: Slibestensfjeldet Fm; V/M Fm: Vaigat/Maligât Fm. Stratigraphy for the Bylot Island: BI Fm: Bylot Island Fm. Time scale is taken from Gradstein et al. (2012).

Fig. 3. Geological map of central west Greenland showing the different volcanic formations and the location of the radiometric samples (yellow, orange and red circles) indicated in Figure 1. The location of the oriented samples of basalt flows, dykes, and sills collected in 2006 are also marked. Onshore wells are indicated: A1: Ataa-1; G1: Gane-1; G3: Gro\#3; Ga1: Gant-1; U1: Umivik-1. 
Fig. 4. Bathymetric map of the NW Atlantic (GEBCO centenary edition). The map shows the location of seismic profiles, Aeromagnetic data extent, as well as the seabed sampling sites used in this study. For more information about the $2 \mathrm{D}$ seismic data as well as the aeromagnetic and gravity data outline and coverage, see http://www.tgs.com/datalibrary/north-america/. Seabed sampling areas, A2 and A5, are indicated in red boxes. Key wells are shown on the map: D-1: Delta-1; G-37: Gjoa; H-1: Hellefisk-1; H-81: Bjarni; I-2: Ikermiut-1; K-1: Kangâmiut-1; K-92: Roberval; M-48: Leif; M-52: Indian Harbour; M-92: Herjolf; N-1 and N-2: Nukik-1 and Nukik-2; N-18: Ralegh; O-71: Hekja; Q-1: Qulleq-1.

Fig. 5. Different seabed sampling techniques used in this study. Gravity coring was used for both stratigraphic and seep sampling. Dredging was used to sample subcropping strata across cliffs (see Supplementary Material 1 for more details on the seabed sampling methodology).

Fig. 6. A: Lava-delta system with well-defined Landward Flows (LF), Lava Delta (LD), and Inner Flows (IF) seismic facies units. The escarpment is indicated. B: Escarpent in Upernavik area. See Figure 4 for locations. Seismic data are in two-way travel time. Data courtesy of TGS.

Fig. 7. A: Well-defined SDR wedge in Northern Labrador Sea. B: SDR wedge in the SW Greenland. A dyke swarm feeder system is interpreted on the seismic transects. See Figure 4 for locations. Seismic data are in two-way travel time. Data courtesy of TGS.

Fig. 8. A: Well-defined SDR wedge in the Davis Strait offshore Cape Dyer. B: Outer SDR wedge identified in SE Baffin Bay. See Figure 4 for locations. Seismic data are in two-way travel time. Data courtesy of TGS. 
Fig. 9. A Volcanic complex in the central Davis Strait. B: sill intrusions and hydrothermal vent complex onlapped by sedimentary strata. See Figure 4 for location. Seismic data are in two-way travel time. Data courtesy of TGS.

Fig. 10. A) Volcanic outcrop in Nuussuaq area showing the foreset-bedded hyaloclastites lava delta unit (analog to the Lava Delta seismic facies unit) which is overlain by thick horizontal lava flows (analog to the Landward Flows seismic facies unit). B) Inclined lava flows (analog to the Inner SDR seismic facies unit) in Svartenkuk Halvø. C) Intra-basalt weathered sediment. D) Saucer-shaped sill intrusion.

Fig. 11. $100 \mathrm{~km}$ high-pass filtered Bouguer anomaly map for the NW Atlantic calculated by TGS based on public satellite gravity data (Sandwell and Smith, 2009). Line YY indicates a continuous anomaly of about $100 \mathrm{mGal}$ identified on the basis of Bouguer gravity map. Dashed black lines indicate a rapid depth variation observed from bathymetry. This feature is less visible in the western Davis Strait and northern Baffin Bay where thick glacial sediment occur. Gravity data courtesy of TGS.

Fig. 12. Total magnetic field map of the NW Atlantic area. The magnetic grid was compiled by TGS and is based on TGS aeromagnetic data for the offshore area, on GEUS (Geological Survey of Denmark and Greenland) aeromagnetic data for onshore Greenland (e.g., Rasmussen, 2002), and the regional magnetic compilation (Verhoef et al., 1996). The data coverage inside the unmasked region is highly improved relative to the rest of the map. However, even with such variation in the data coverage and, then in the grid resolution, the different magnetic domains are defined with a good confidence on the Greenland and the Canadian sides. The map shows interpreted linear magnetic anomalies (XX, X0, X1, X2 and X3) and magnetic domains bounded by them. Major orogenic belts of the Greenland 
basement are indicated in the upper right corner map (e.g., Braun et al., 2007; Abdelmalak et al., 2013). ESR is extinct spreading ridge. Magnetic data courtesy of TGS.

Fig. 13. Integrated seismic gravity and magnetic interpretation showing the different magnetic and gravimetric anomalies, domains and boundaries in the Labrador Sea. Black arrows indicate the top basement location whereas blue arrows show strong reflections identified landward of line X1. See Figure 12 for location of profiles. Data courtesy of TGS.

Fig. 14. Integrated seismic gravity, and magnetic interpretation in the southern Davis Strait (A) and in the Baffin Bay (B). B: Basalt; S: Sill; U: Ungava positive gravity anomaly. See Figure 12 for location of profiles. Data courtesy of TGS.

Fig. 15. Seismic profiles along the identified escarpments in the Melville Bay. Locations of the gravity core stations and dredge profiles in A2 (A) and A5 areas (B) are indicated. C: Example of near in situ samples of Early Turonian source rock from Area A2 recovered after washing the mud at the base of the gravity core. D: Early Turonian palynomorphs from A2 gravity cores. E: Eocene basalt sample from dredged rocks in A5 area. See Figure 4 for locations of A2 and A5.

Fig. 16. A: Total alkali vs $\mathrm{SiO}_{2}$ diagram (wt. \%) for the offshore dredged basalt samples from Upernavik Escarpment. B: $\mathrm{Ce} / \mathrm{Y}$ and $\mathrm{Zr} / \mathrm{Nb}$ variation for the Upernavik Escarpment basalts and onshore Greenland volcanic formations. C and D: REE diagram normalized to chondrite and multi-element diagram normalized to Primitive Mantle (McDonough and Sun, 1995) diagram for the Upernavik Escarpment basalt. Typical values for N-type and E-type MORB and OIB are plotted. The compositions for on land volcanic formations are from Larsen et al. (2015) and L. M. Larsen and J. G. Larsen (pers. comm., 2017). 
Fig. 17. Geological map of the NW Atlantic showing the sedimentary basins, the different crustal types and structures identified from seismic, gravity and magnetic data. The different mapped volcanic facies units are indicated. Offshore wells where volcanism has been drilled are indicated. CD: Cape Dyer; D: Disko; DH: Disko High; FSC: Fylla Structure Complex; HB: Hopedale Basin; HH: Hecla High; KB: Kivoq Basin; KH: Kangeq High; LFP: Lady Franklin Basin; N: Nuussuaq; NP: Nukik Platform; MB: Melville Bay Basin; SaB: MH: Maniitsoq High; Saglek Basin; SB: Sisimiut Basin; SH: Svartenhuk halvø; UB: Upernavik Basin.

Fig. 18. A, B, C and D: Plate reconstruction model keeping North America fixed (blue lines) with respect to Greenland (red lines). Small circles (grey lines) show direction of plate displacement; note major change in plate motion at 56 Ma (C24: Paleocene-Eocene boundary). Dashed line indicated the location of fracture zones. E: Displacement of fixed positions on Greenland in $2 \mathrm{Ma}$ increments based on our final plate tectonic model. F: Stage pole location for different plate tectonic models (Bullard et al., 1965; Torsvik et al., 2008; Oakey and Chalmers, 2012). Eurekan fold and thrust belt is not restored in this study. LS: Lancaster Sound.

Fig. 19. Tectonomagmatic evolution of the NW Atlantic area with a correlation to the main regional tectonic events in the North Atlantic and Arctic areas (Faleide et al., 1993; Whittaker et al., 1997; Japsen and Chalmers, 2000; Skogseid et al., 2000; Hamann et al., 2005; Oakey and Stephenson, 2008; Schenk, 2011; Chalmers, 2012; Oakey and Chalmers, 2012). Arrow indicates the precise ages for the tectonic events. Time scale is taken from Gradstein et al. (2012). Purple color corresponds to main magmatic events in the NW Atlantic area.

\section{Table caption}


Table 1. Description of the volcanic seismic facies units based on (Planke et al., 2000), Berndt et al. (2001), Jerram et al. (2009), and Abdelmalak et al. (2016a, b). 


\begin{tabular}{|c|c|c|c|c|c|}
\hline \multirow{2}{*}{$\begin{array}{l}\text { Seismic } \\
\text { facies unit }\end{array}$} & \multicolumn{3}{|c|}{ Reflection characteristics } & \multirow{2}{*}{ Volcanic facies } & \multirow{2}{*}{$\begin{array}{l}\text { Depositional } \\
\text { environment }\end{array}$} \\
\hline & Shape & Boundaries & Internal & & \\
\hline $\begin{array}{l}\text { Inner } \\
\text { Flows }\end{array}$ & Sheet & $\begin{array}{l}\text { Top: high } \\
\text { amplitude, } \\
\text { disrupted, rough } \\
\text { being onlapped or } \\
\text { concordant } \\
\text { Base: negative } \\
\text { polarity often } \\
\text { obscured }\end{array}$ & $\begin{array}{l}\text { Chaoitic } \\
\text { sheet-like } \\
\text { body of very } \\
\text { disrupted or } \\
\text { hummocky } \\
\text { reflections }\end{array}$ & $\begin{array}{l}\text { Massive and } \\
\text { fragmented } \\
\text { flows, } \\
\text { volcanoclastics } \\
\text { and } \\
\text { hyaloclastics }\end{array}$ & $\begin{array}{l}\text { Shallow } \\
\text { marine } \\
\text { deposited in } \\
\text { broad basin }\end{array}$ \\
\hline Lava Delta & Bank & $\begin{array}{l}\text { Top: high } \\
\text { amplitude or } \\
\text { reflection } \\
\text { truncation } \\
\text { Base: reflection } \\
\text { truncation or } \\
\text { termination }\end{array}$ & $\begin{array}{l}\text { Progradationa } \\
1 \text { reflection } \\
\text { configuration }\end{array}$ & $\begin{array}{l}\text { Massive and } \\
\text { fragmented } \\
\text { basalts and } \\
\text { volcanoclastics }\end{array}$ & Coastal \\
\hline $\begin{array}{l}\text { Landward } \\
\text { Flows }\end{array}$ & Sheet & $\begin{array}{l}\text { Top: high } \\
\text { amplitude, } \\
\text { smooth being } \\
\text { onlapped or } \\
\text { concordant } \\
\text { Base: law } \\
\text { amplitude, } \\
\text { disrupted }\end{array}$ & $\begin{array}{l}\text { Parallel to } \\
\text { subparallel. } \\
\text { High- } \\
\text { amplitude } \\
\text { disrupted }\end{array}$ & Flood basalts & $\begin{array}{l}\text { Subaerial or } \\
\text { shallow } \\
\text { marine } \\
\text { flood basalts } \\
\text { deposited on } \\
\text { a plain or in } \\
\text { broad basin }\end{array}$ \\
\hline Inner SDR & Wedge & $\begin{array}{l}\text { Top: intermediate } \\
\text { to high amplitude, } \\
\text { smooth with } \\
\text { pseudoescarpmen } \\
\text { t Base: }\end{array}$ & $\begin{array}{l}\text { Divergent } \\
\text { arcuate or } \\
\text { sometimes a } \\
\text { divergent- } \\
\text { planar pattern }\end{array}$ & Flood basalts & $\begin{array}{l}\text { Subaerial } \\
\text { flood basalts } \\
\text { deposited in } \\
\text { subsiding } \\
\text { structure }\end{array}$ \\
\hline $\begin{array}{l}\text { Outer } \\
\text { High }\end{array}$ & & $\begin{array}{l}\text { Top: high } \\
\text { amplitude, } \\
\text { disrupted and } \\
\text { rough } \\
\text { Base: not visible }\end{array}$ & Chaotic & $\begin{array}{l}\text { Hyaloclastic } \\
\text { flows and } \\
\text { volcanoclastics }\end{array}$ & $\begin{array}{l}\text { Shallow } \\
\text { marine } \\
\text { environment }\end{array}$ \\
\hline Outer SDR & Wedge & $\begin{array}{l}\text { Top: intermediate } \\
\text { to high amplitude, } \\
\text { smooth with } \\
\text { pseudoescarpmen } \\
\text { t Base: } \\
\text { seldom defined }\end{array}$ & $\begin{array}{l}\text { Divergent } \\
\text { arcuate } \\
\text { internal } \\
\text { reflectors, } \\
\text { lower } \\
\text { amplitude } \\
\text { than the Inner } \\
\text { SDR }\end{array}$ & $\begin{array}{l}\text { Flood basalts } \\
\text { mixed with } \\
\text { pillow basalts } \\
\text { sediments and } \\
\text { sills }\end{array}$ & $\begin{array}{l}\text { Deep } \\
\text { marine } \\
\text { depositional } \\
\text { environment }\end{array}$ \\
\hline $\begin{array}{l}\text { Lava } \\
\text { Flows }\end{array}$ & Sheet & $\begin{array}{l}\text { Top: high } \\
\text { amplitude with } \\
\text { pseudoescarpmen }\end{array}$ & Chaotic & Flood basalts & $\begin{array}{l}\text { Subaerial to } \\
\text { shallow } \\
\text { submarine }\end{array}$ \\
\hline
\end{tabular}


Table 1: 


\section{Highlights}

- Determination of the tectonomagmatic evolution of the NW Atlantic

- Mapping of the breakup-related magmatism using the vocanostratigraphy concept

- Mapping of the crustal domain and boundaries using integrated SGM method

- Analyses of seabed and onshore samples and field analogues work

- New plate tectonic reconstruction for the NW Atlantic 


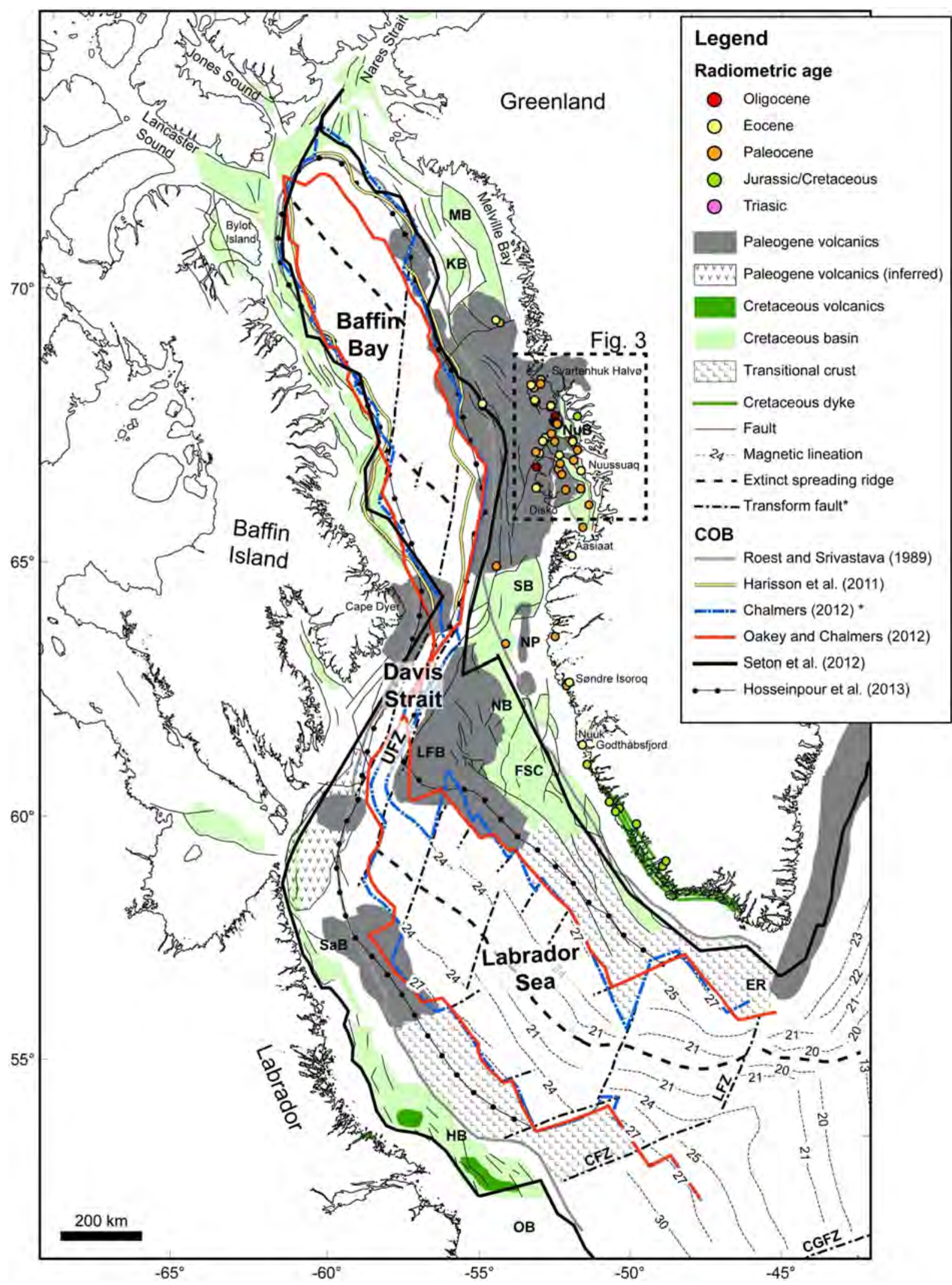




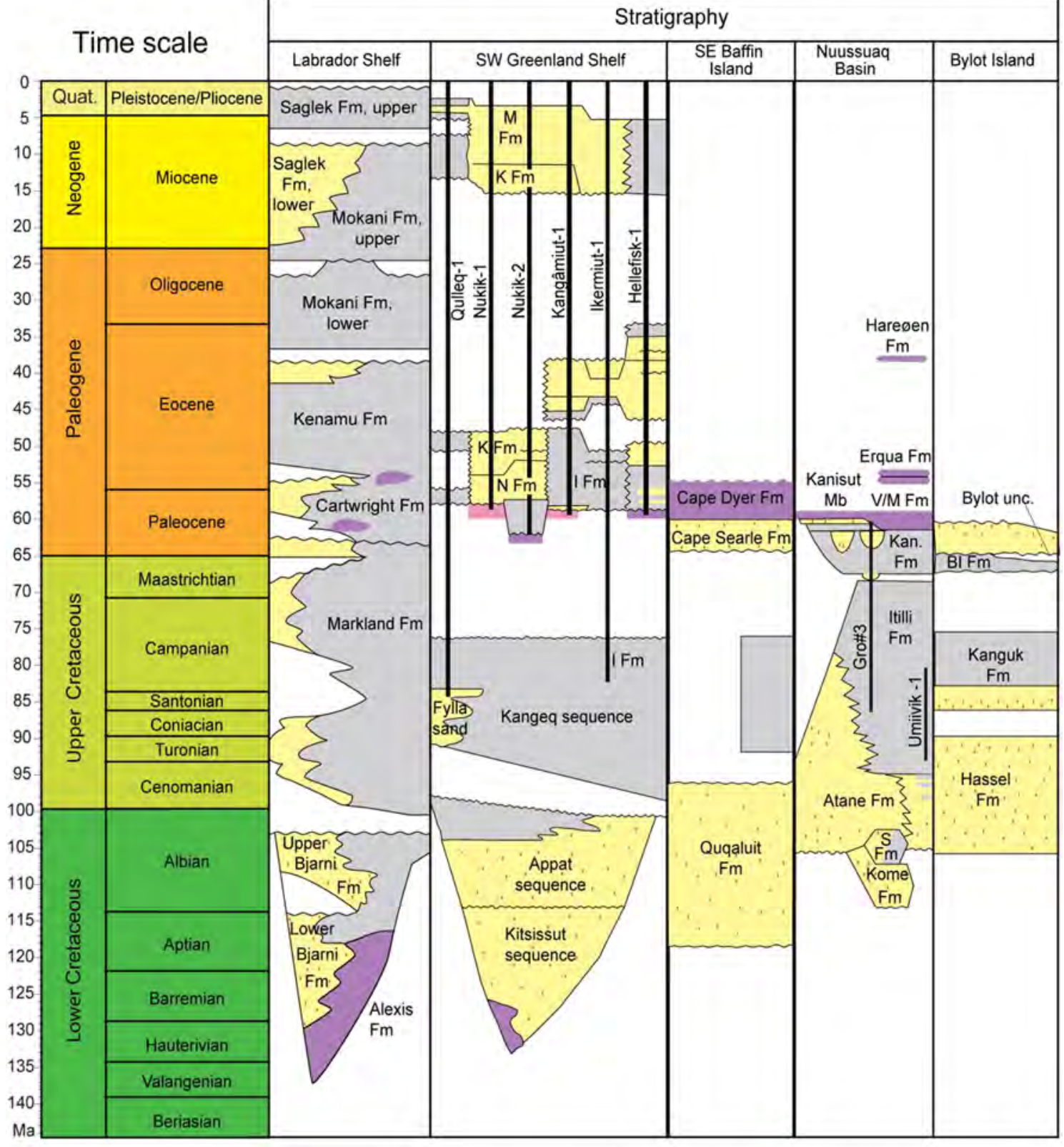

Mainly marine mudstone/shale deposits

Mainly marine or deltaic sandy/silty deposits

Volcanics

Basement

Continental deposits 


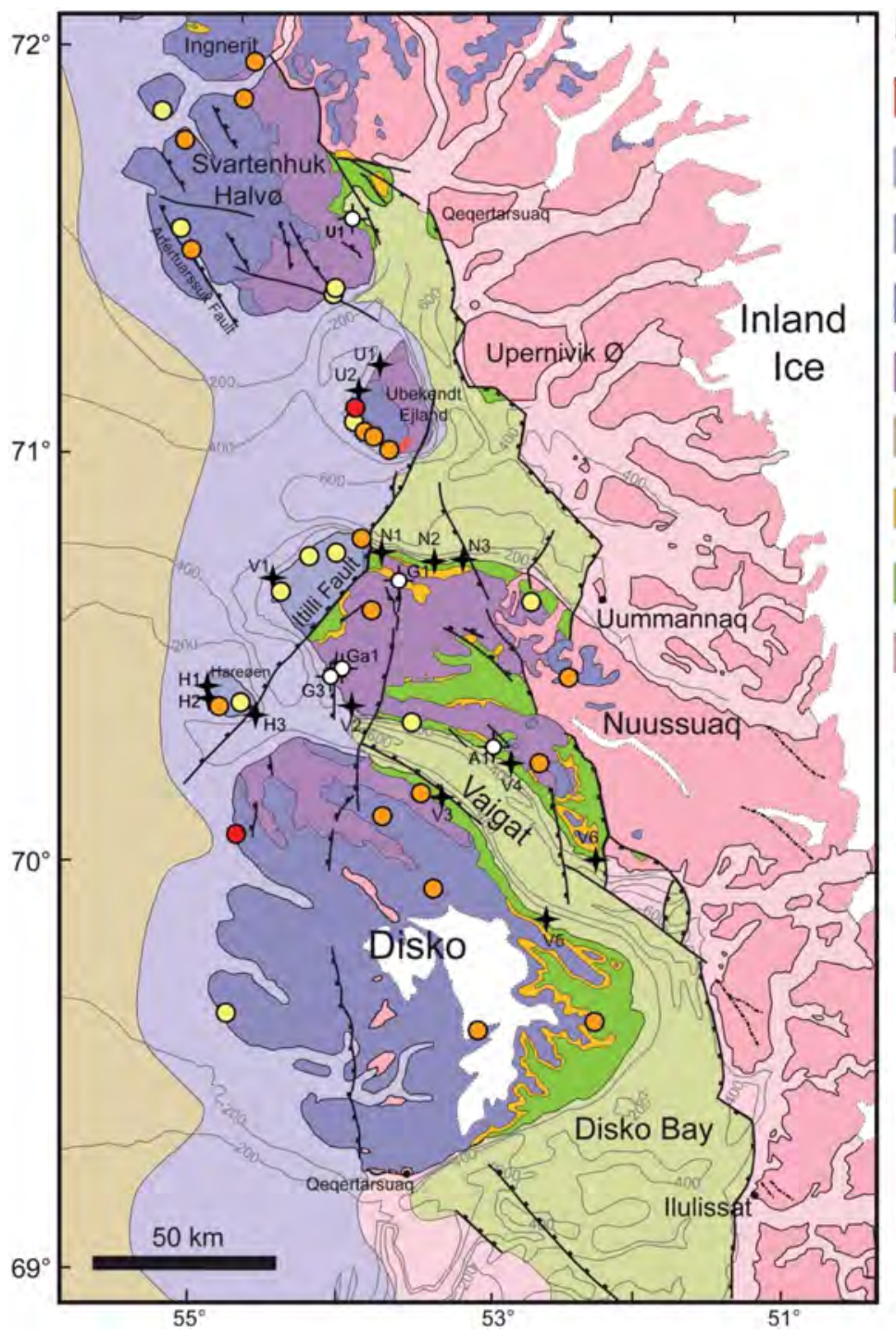

Paleogene intrusive complex

Paleogene offshore basalts

Eocene units

Svartenhuk/Maligât formations

Vaigat Formation

Eocene and younger sediments

Maastrichtian-Paleocene sediments

Albian-Campanian sediments

Precambrian basement

Depth in metres below sea-level

Extensional fault

....... Shear zone

$+\quad$ Magnetic sampling

- - Well

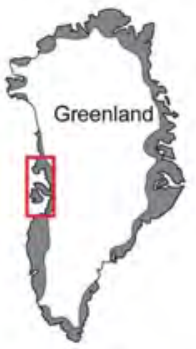

Figure 3 


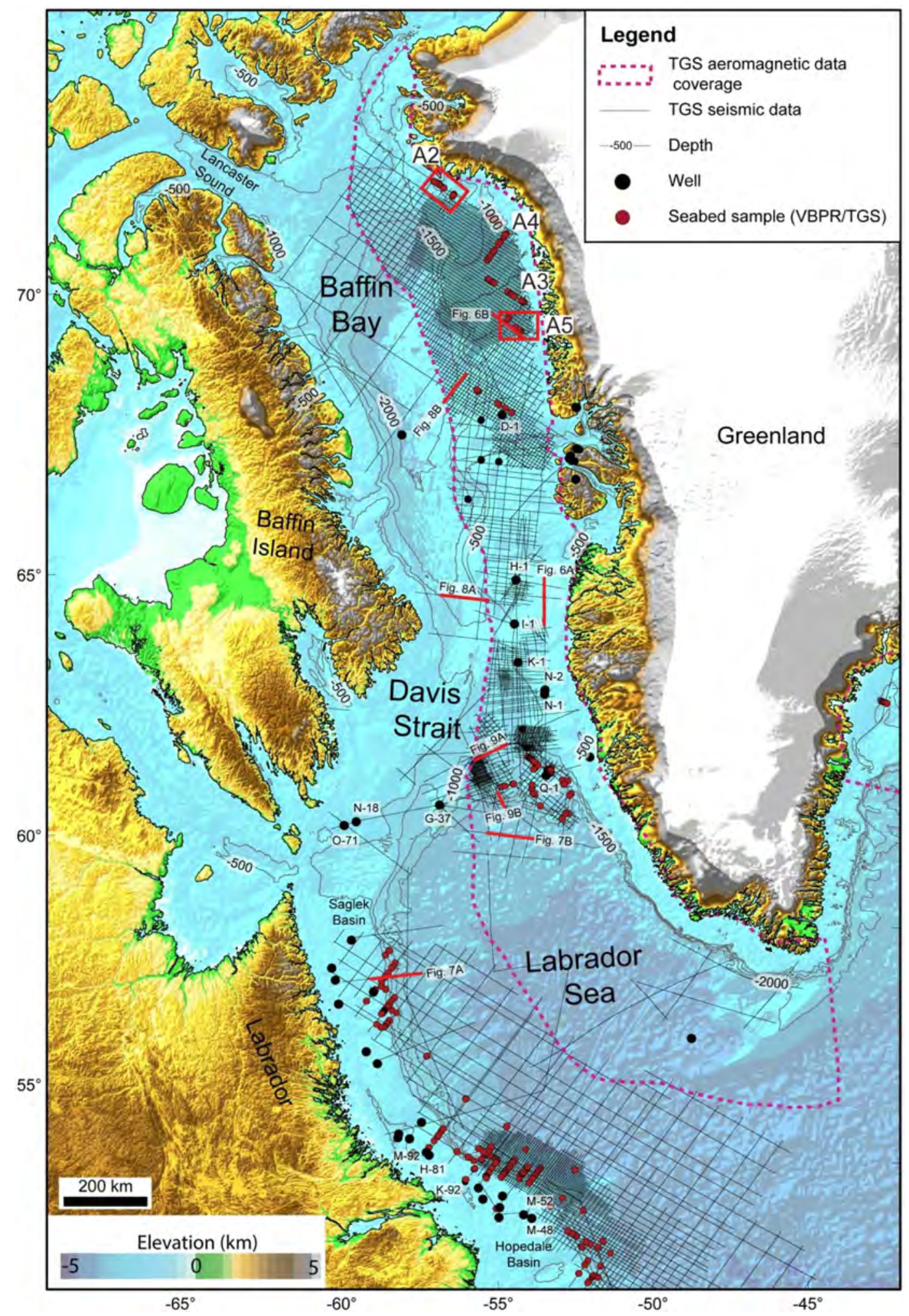



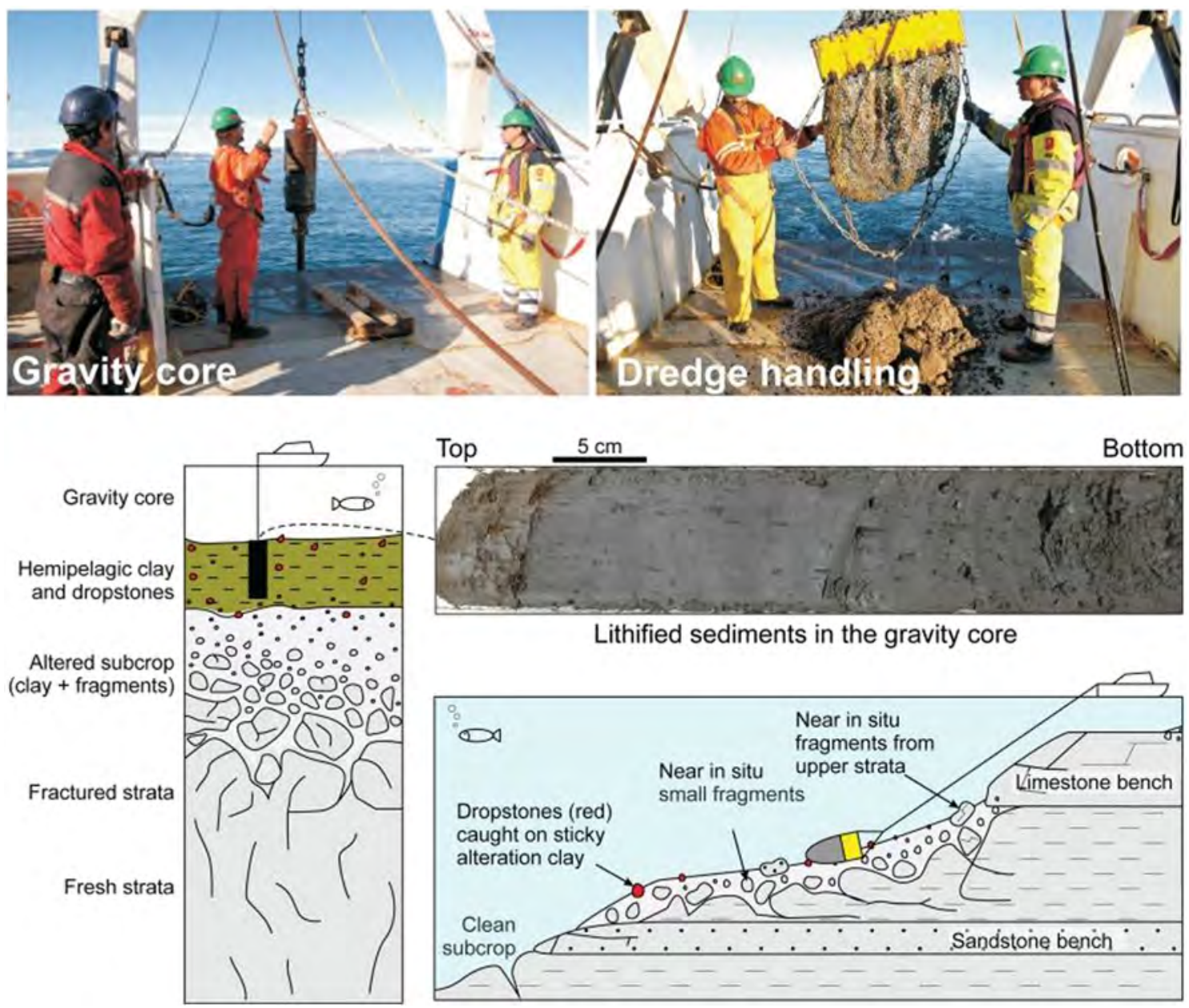

Figure 5 

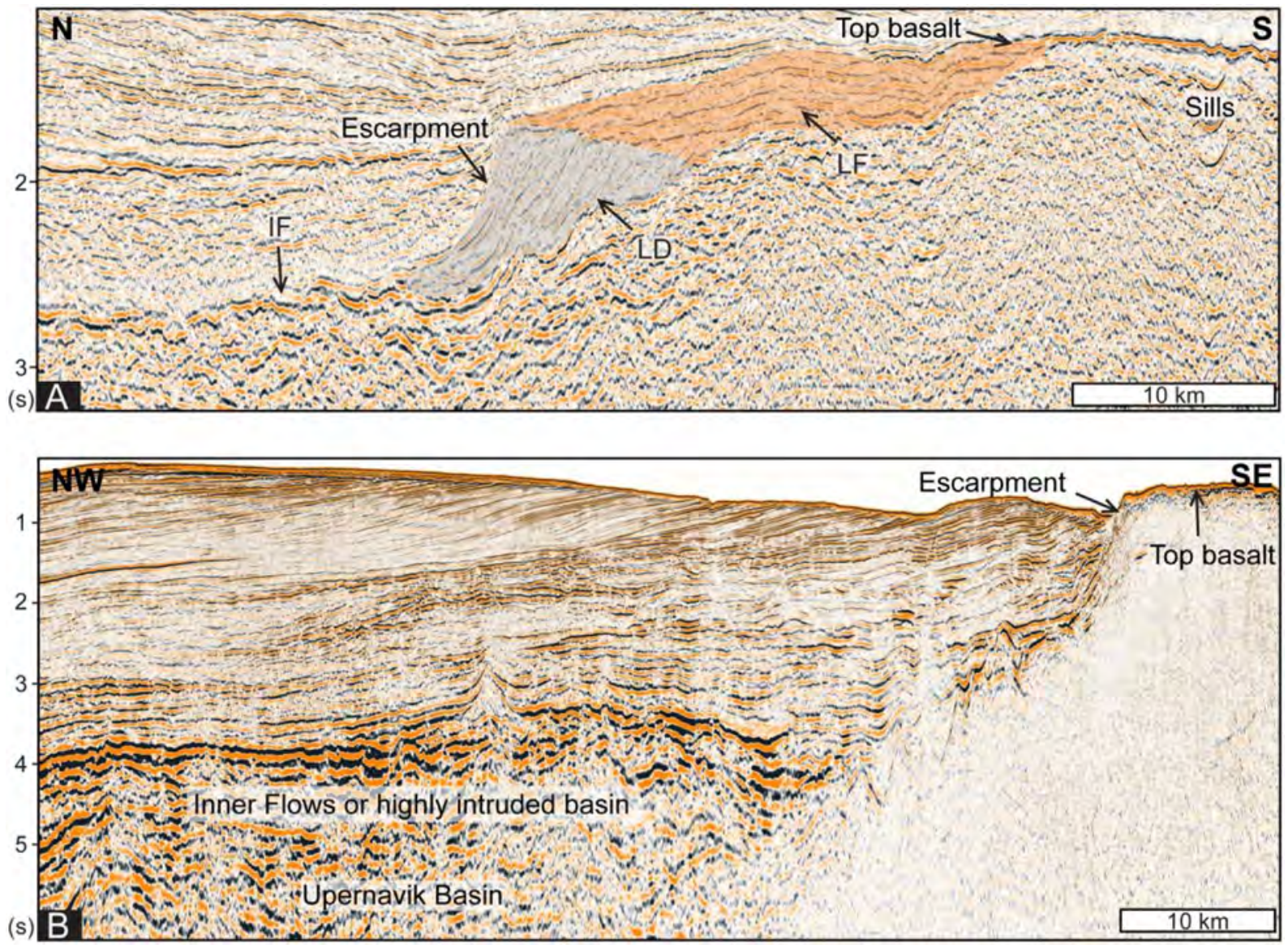

Figure 6 

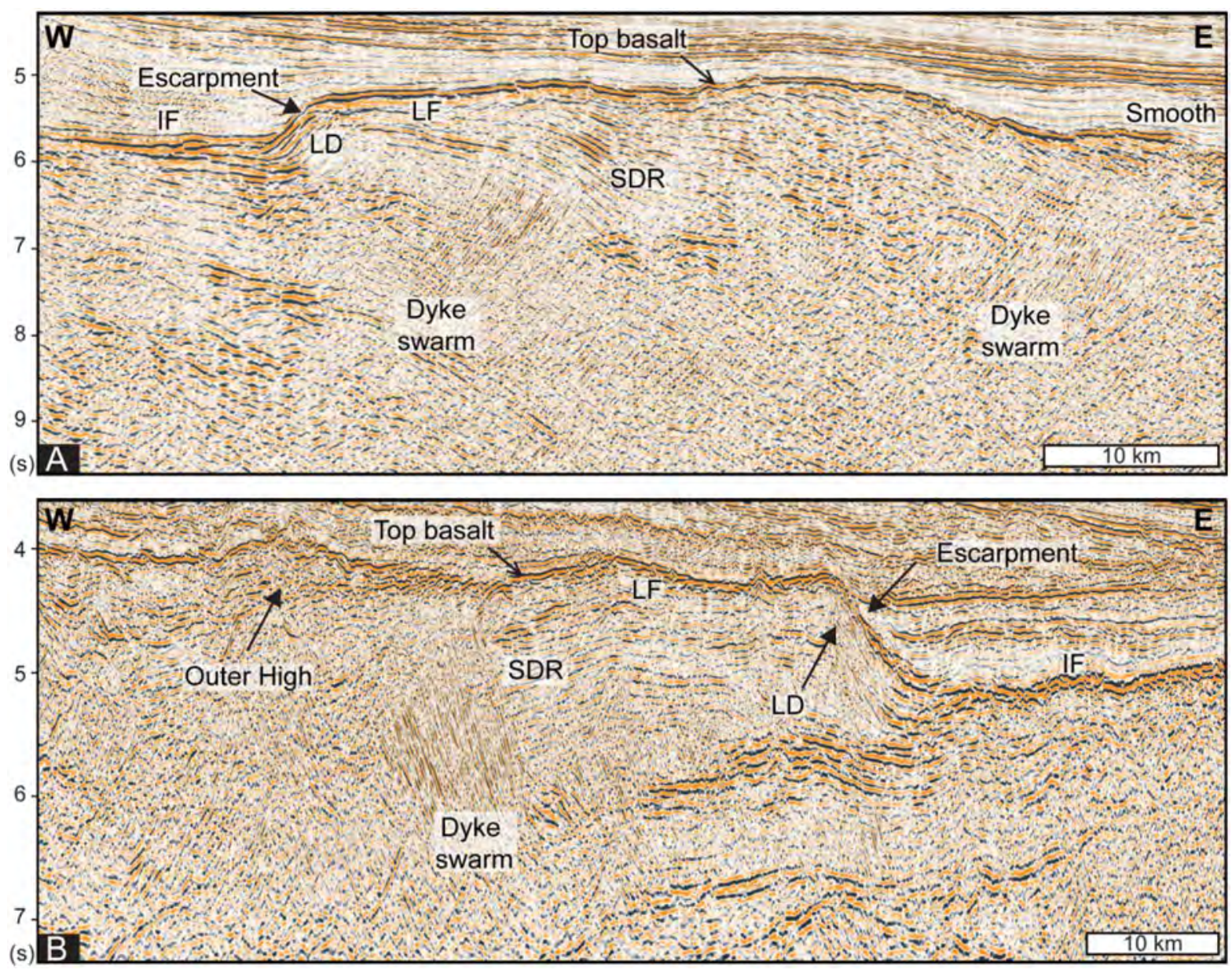

Figure 7 

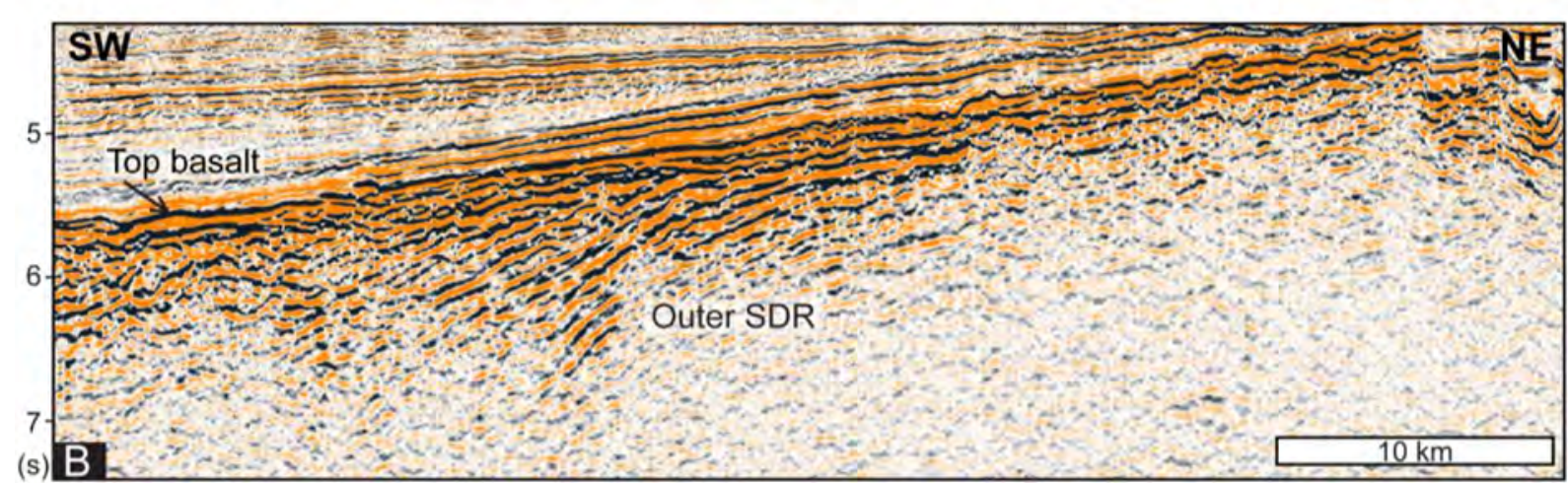

Figure 8 

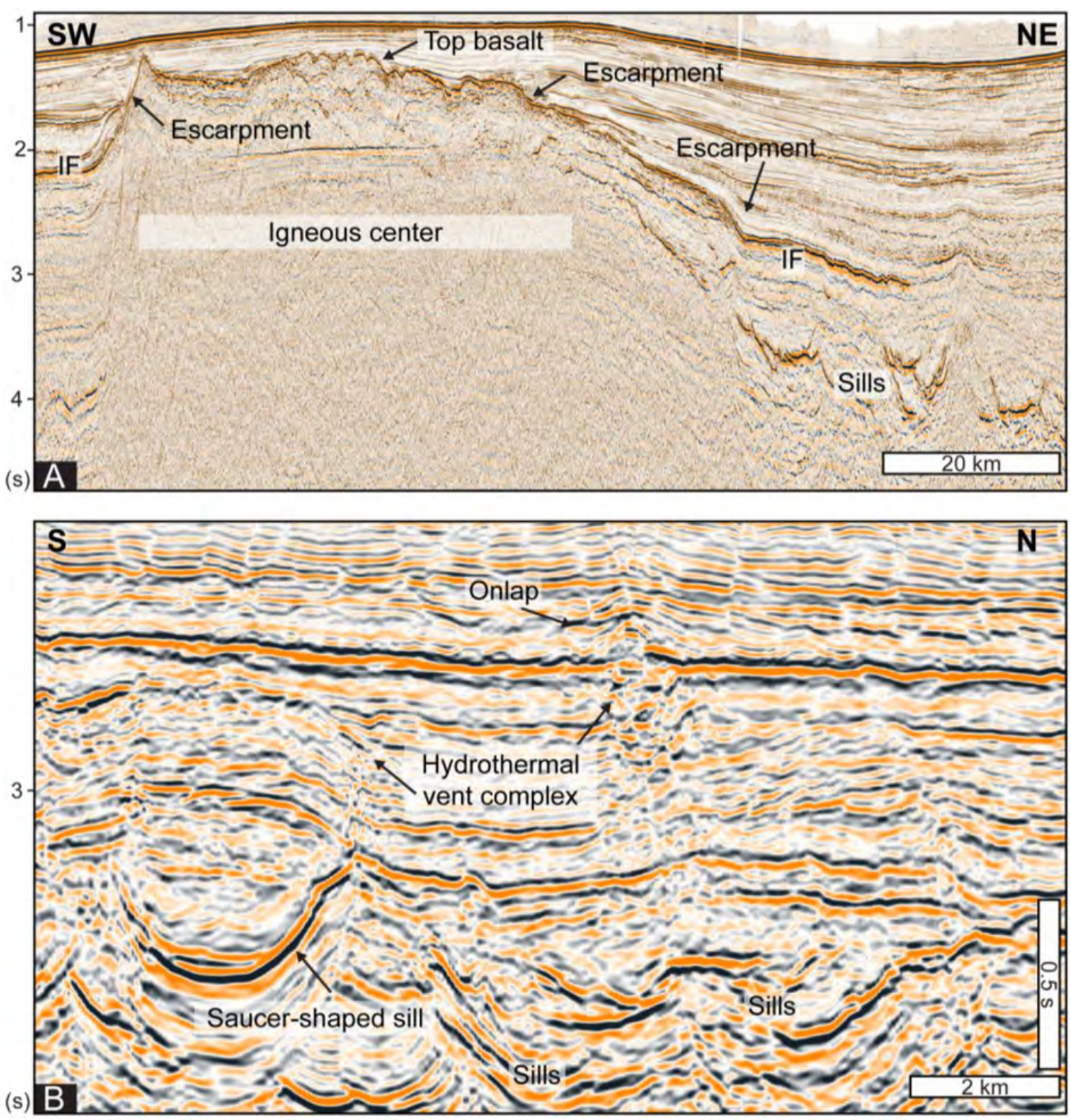

(s)

Figure 9 

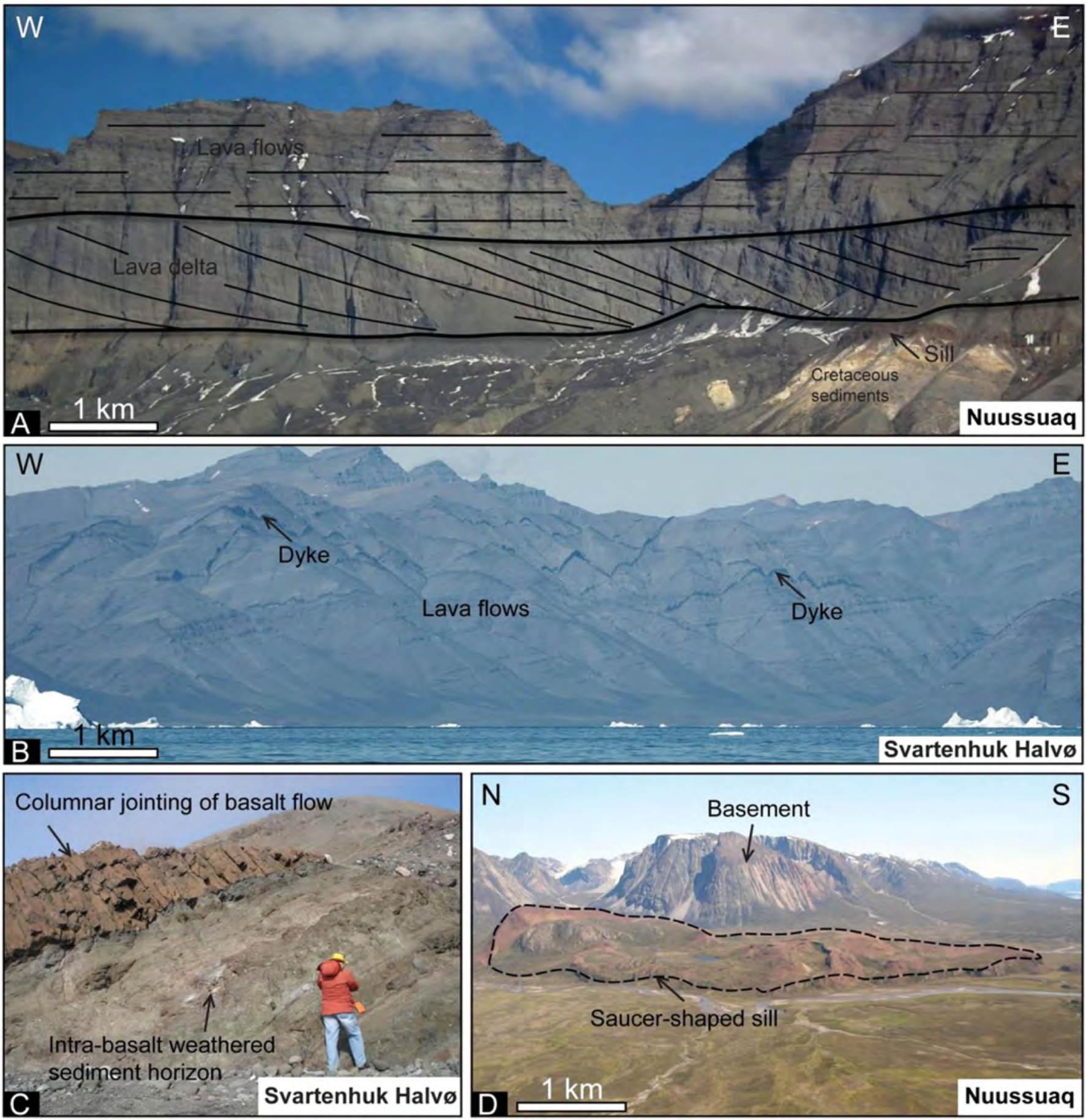


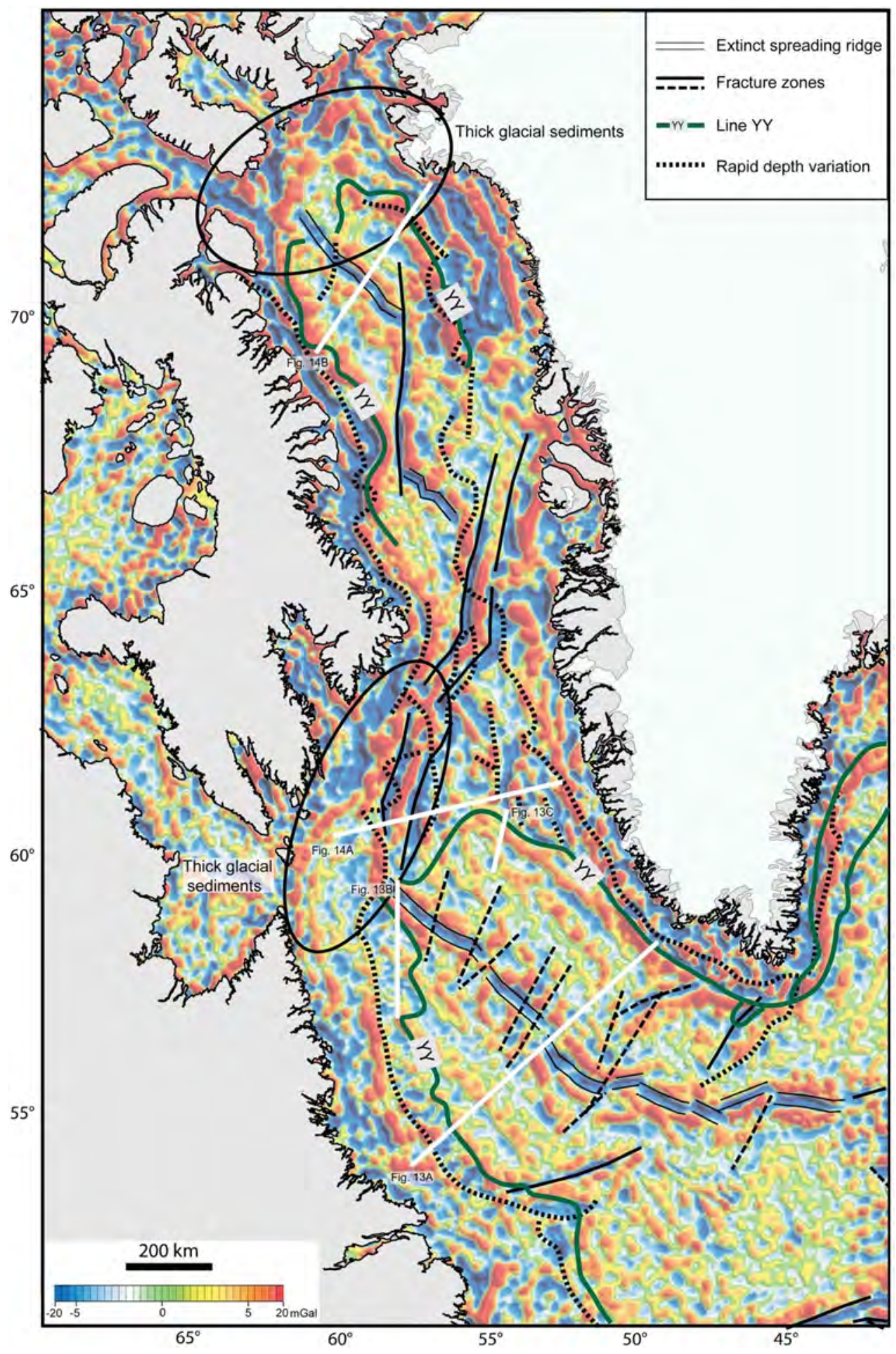




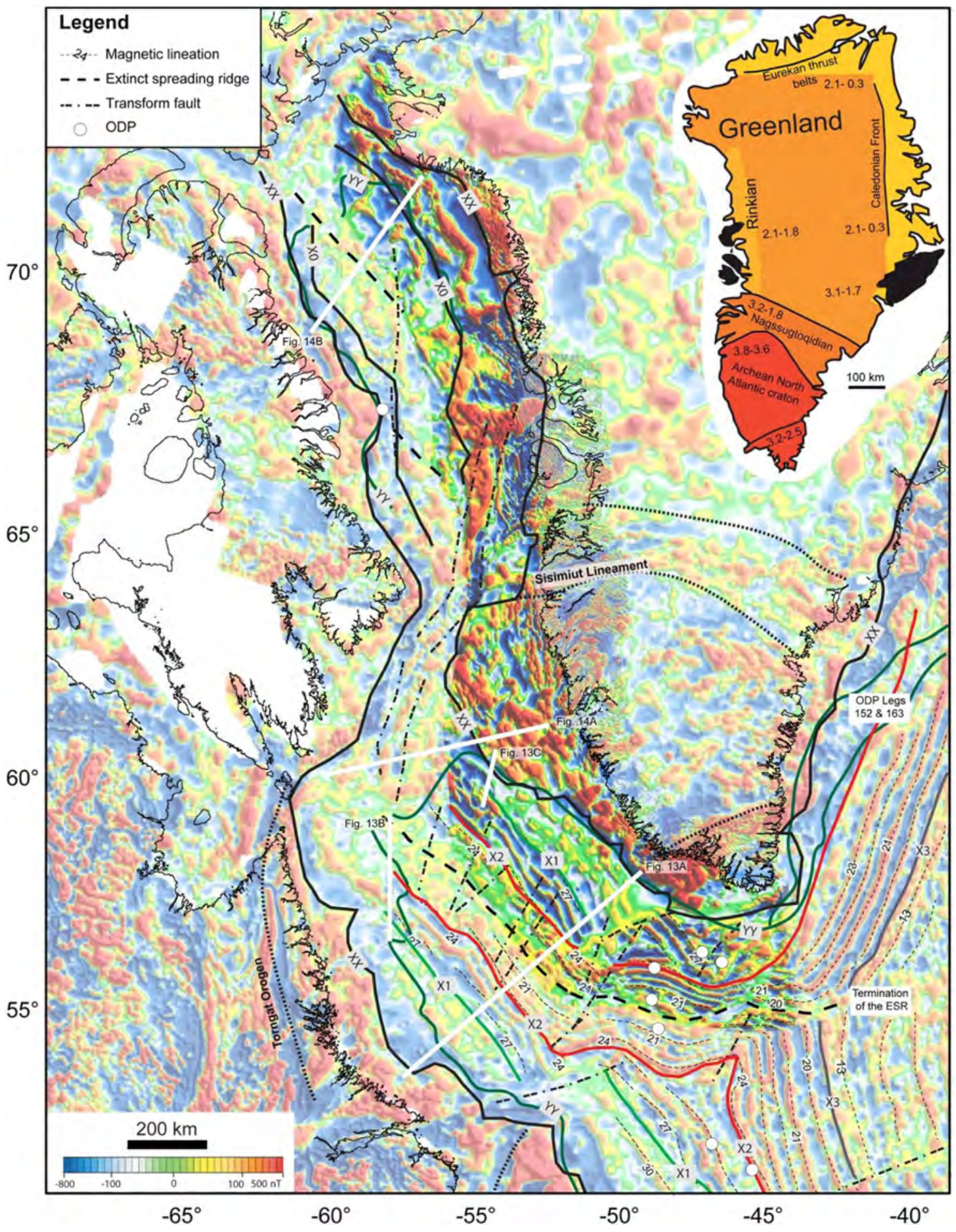



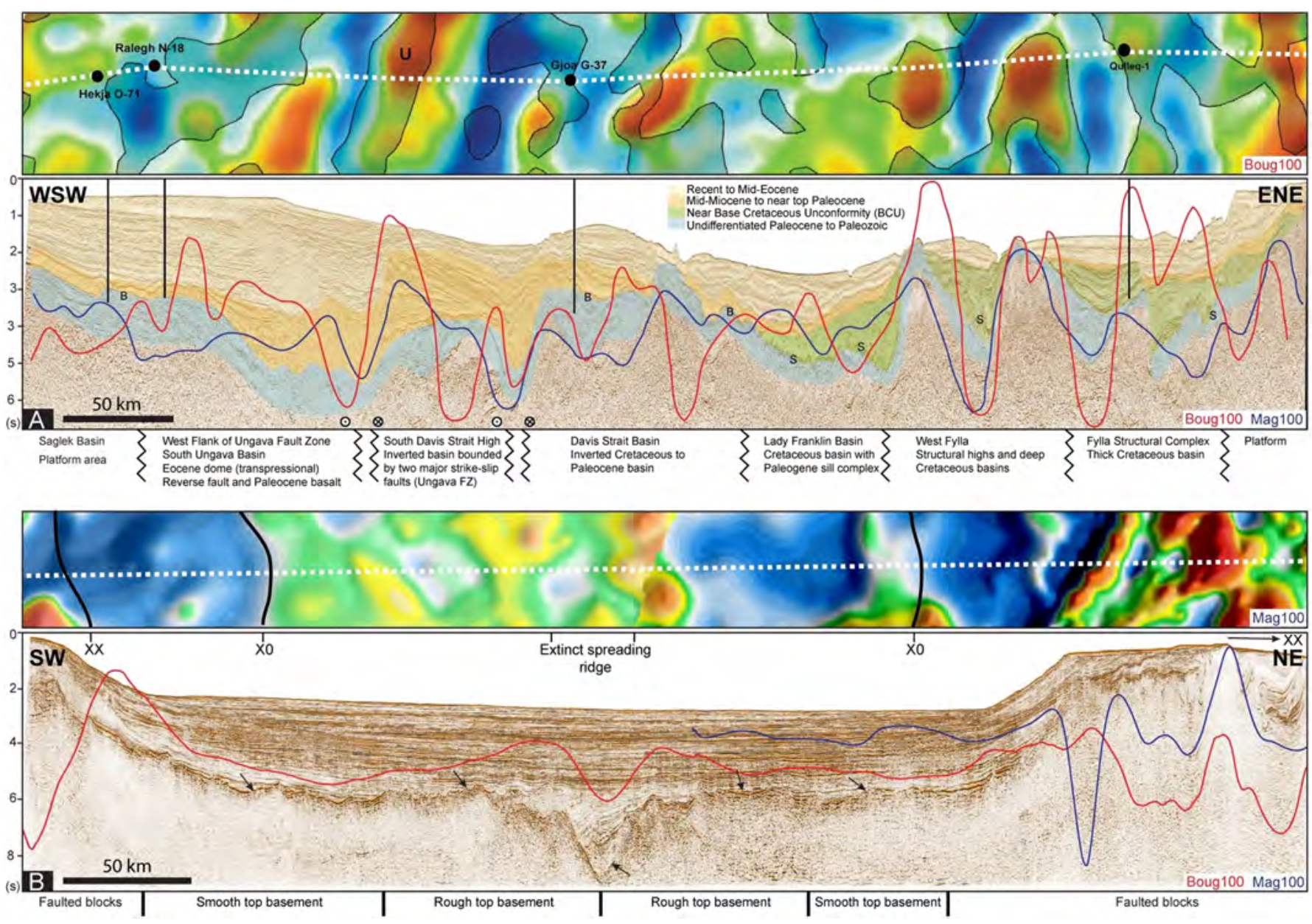

Figure 14 


\section{A2 location}

$\downarrow$ Gravity core station

$\rightarrow$ Dredge profile

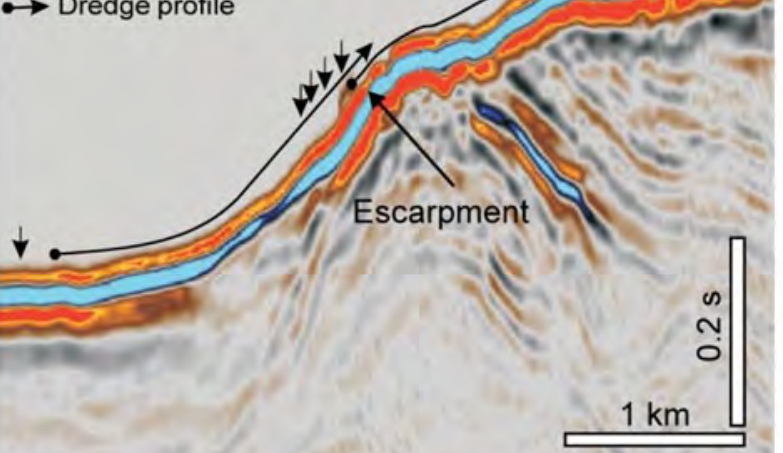

\section{A $\quad y=$ Sedimentary escarpment}

\section{A5 location}

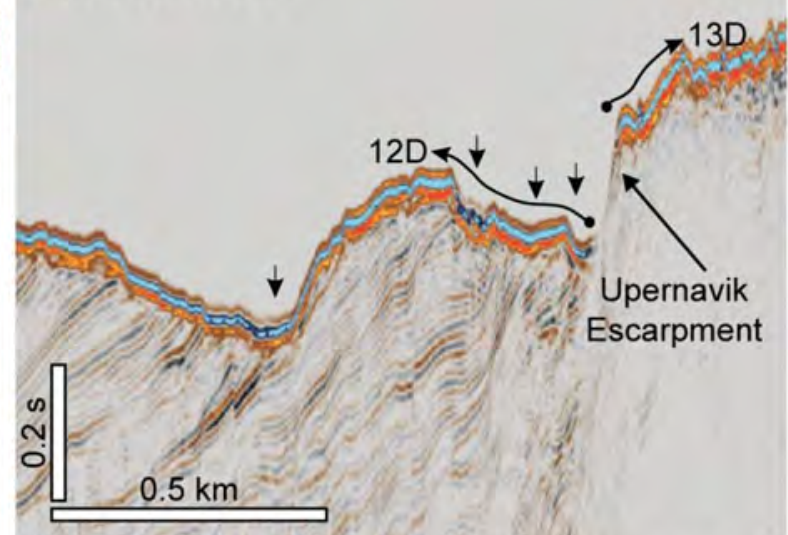

Volcanic escarpment
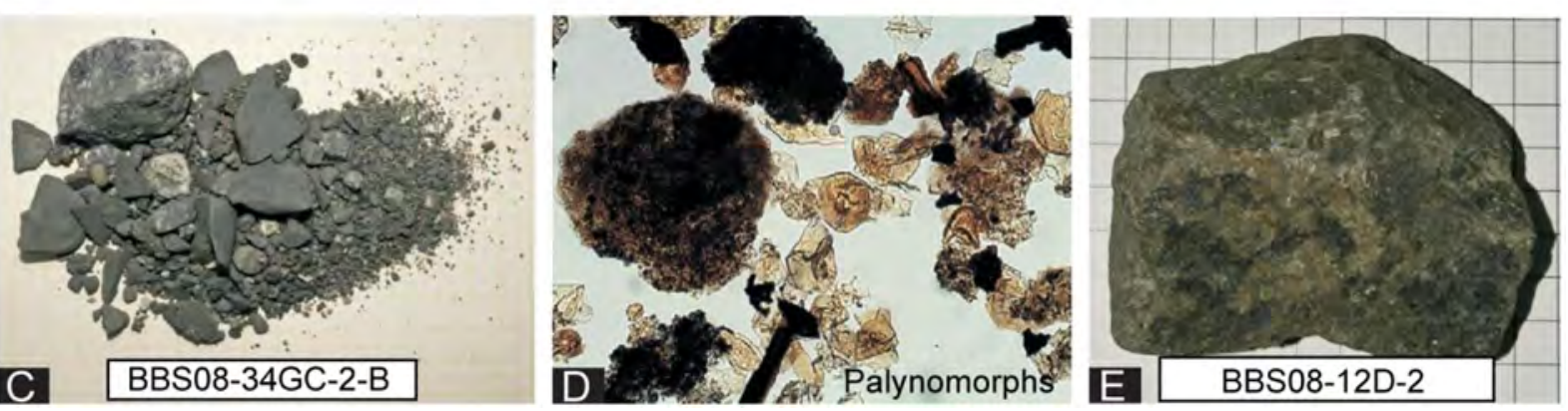

Figure 15 

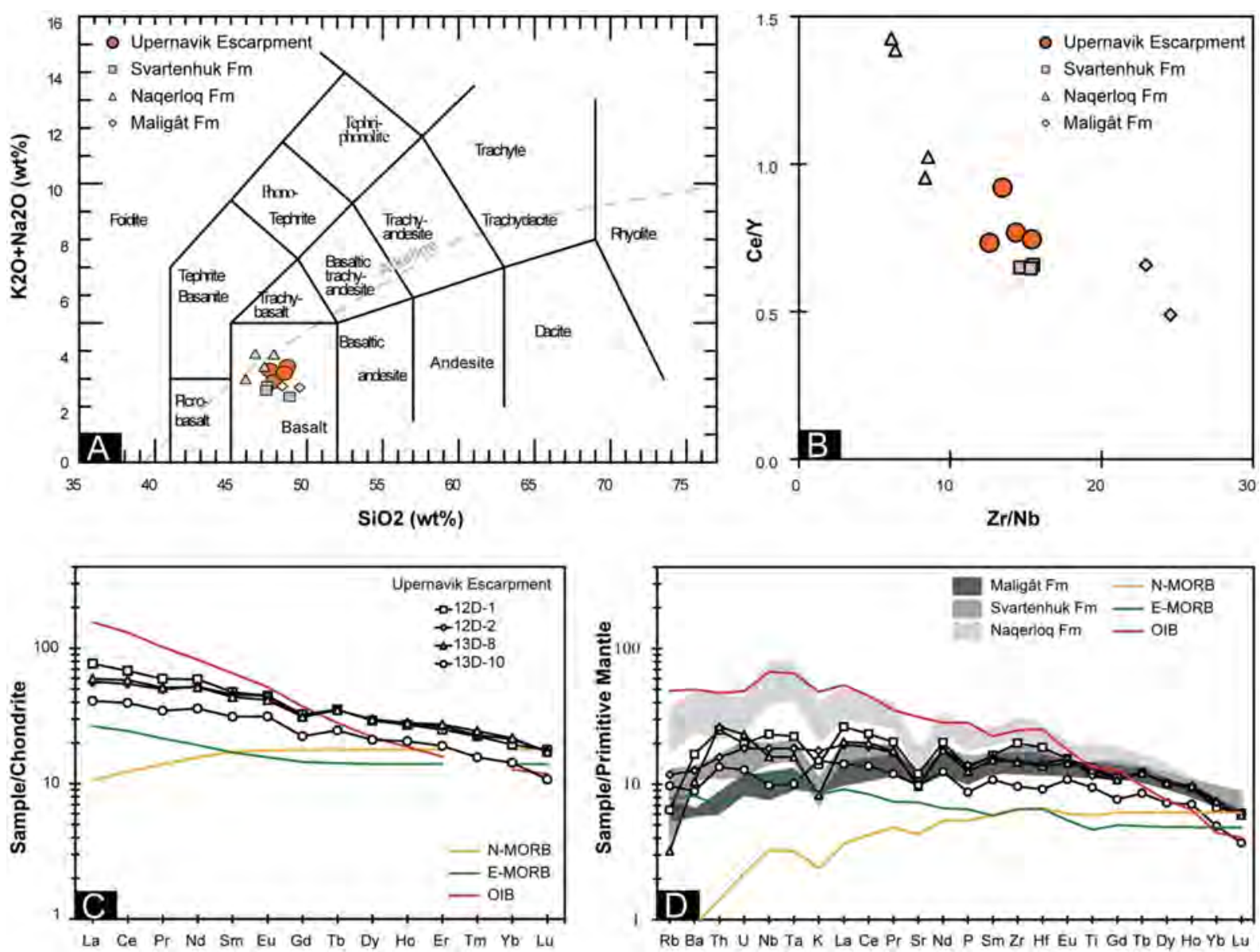

Rb Ba Th U Nb Ta K La Ce Pr Sr Nd P Sm Zr Hf Eu Ti Gd Tb Dy Ho Yb Lu

Figure 16 


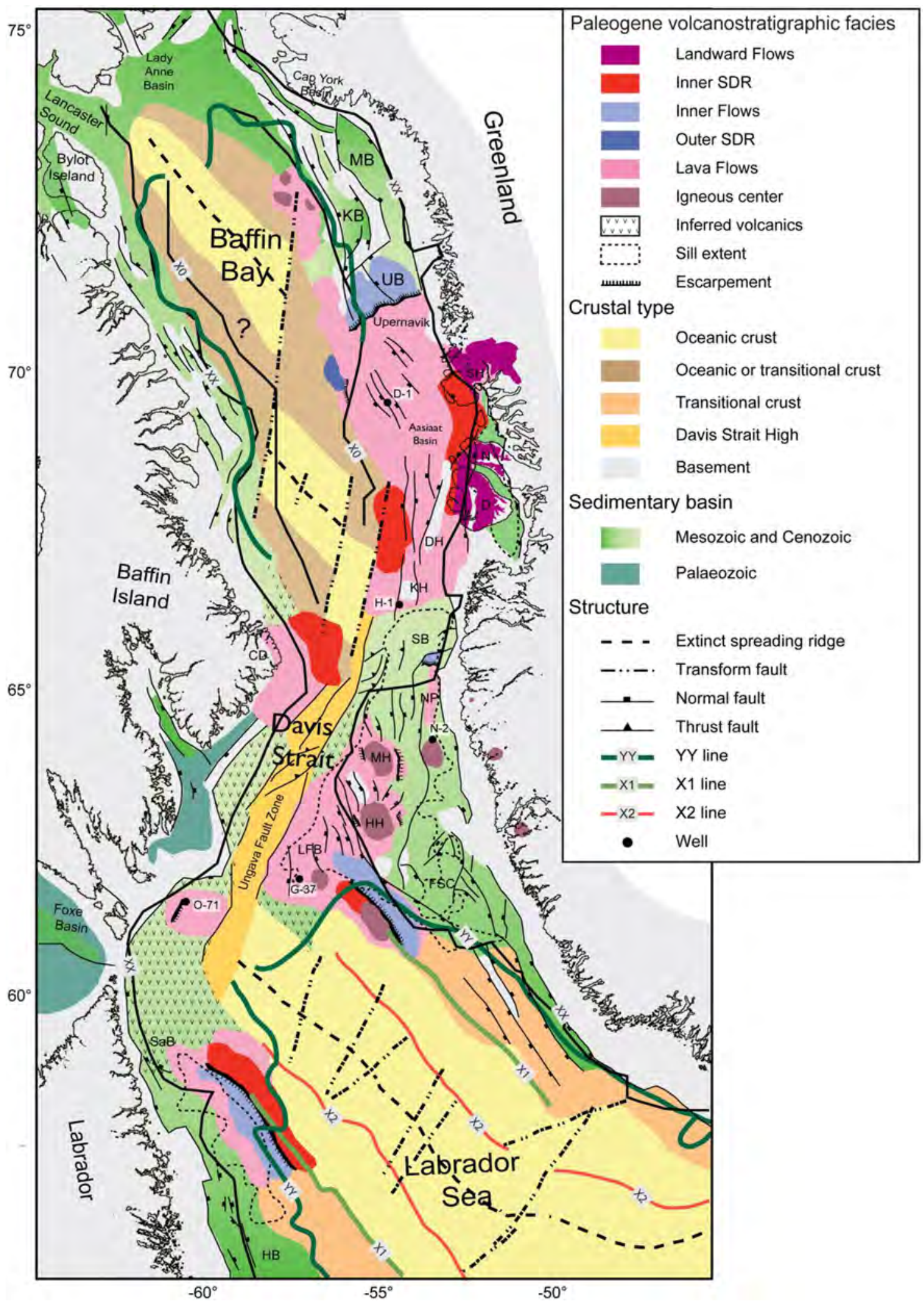



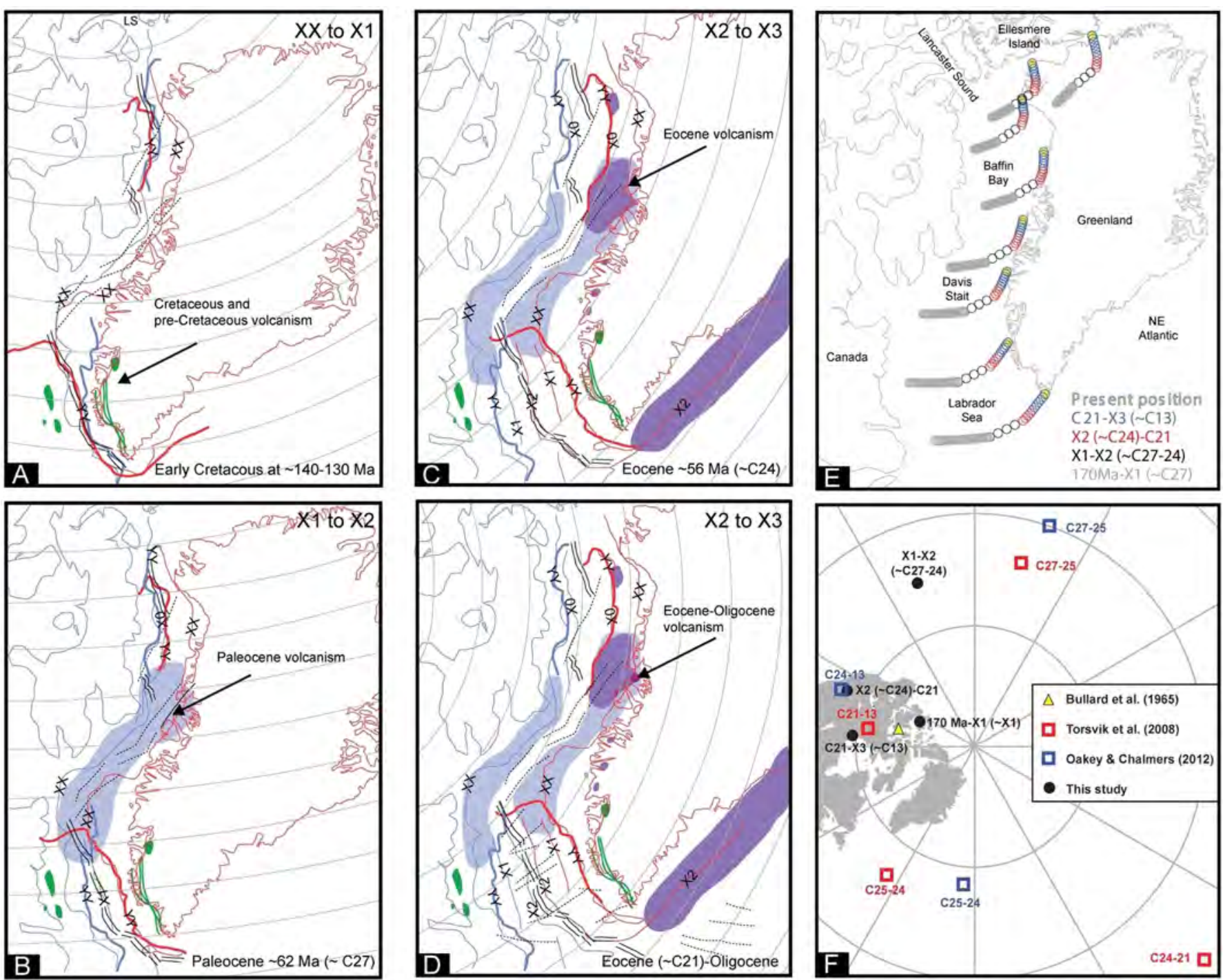

Figure 18 


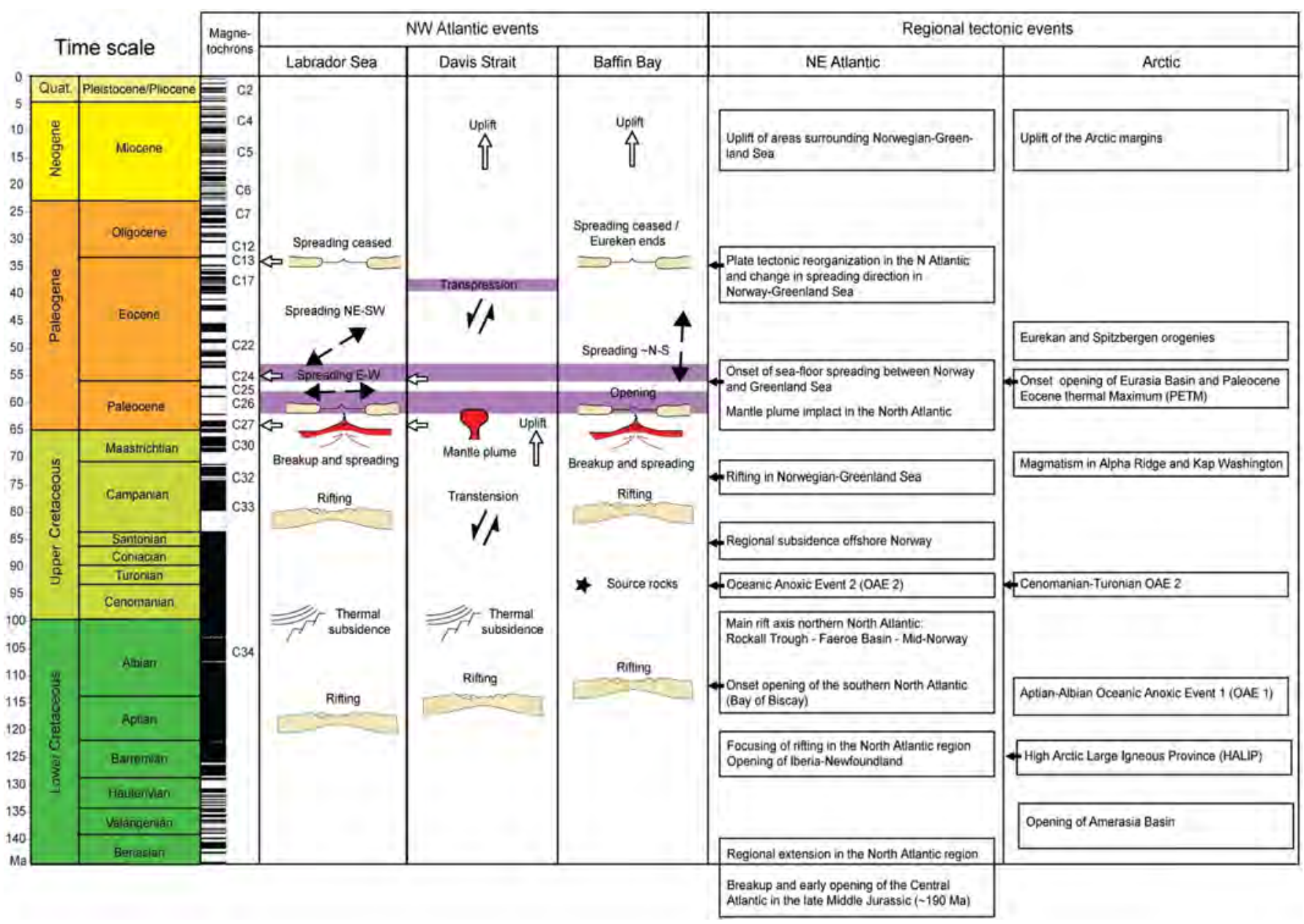

